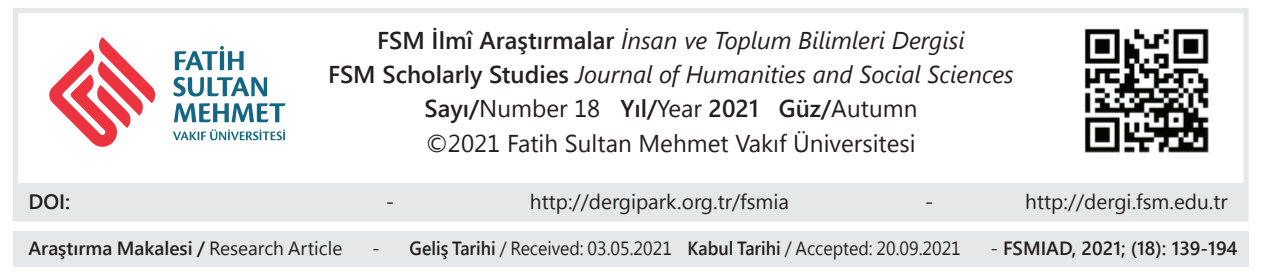

\title{
Acem Serhaddinde Cafer Paşalar: Tebriz ve Şirvan Eyaletlerinin Muhafazası (1583-1591) \\ Emirhan Özçelik*
}

\section{$\ddot{O} z$}

1578-1590 seneleri arasında meydana gelen Osmanlı-Safevi mücadeleleri pek çok muharebe ve kuşatmaya sahne olmuştur. Bu seferlerde Osmanlı orduları Şirvan ve Tebriz gibi önemli şehirleri ve etrafındaki bölgeleri fethetmeyi başarmıştır. Seferler devam ettiği ve Osmanlı kazançları henüz resmiyet kazanmadığı için fethedilen bu yerlerin muhafazası ve idare edilmesi gerekmiştir. Şirvan ve Tebriz'de Osmanlı hakimiyetinin temelini atmak ise adaş iki paşaya nasip olmuştur. Aynı zaman aralığında Şirvan'da Emektar Cafer Paşa, Tebriz'de Hadım Cafer Paşa birçok sıkıntı ve zorlukla mücadele ederek fethedilen bu yeni bölgelerde Osmanlı yönetiminin yerleşmesi ve askerî düzenin kurulmasını sağlamıştır. İki devlet adamının Acem serhaddindeki tecrübeleri ve başarıları seferlerin ve Acem serhaddinin tarihinde önemli bir yeri vardır. Bu makalede Cafer Paşaların uzun senelere yayılan faaliyetleri incelenecektir.

Anahtar Kelimeler: Emektar Cafer Paşa, Hadım Cafer Paşa, Şirvan, Tebriz, Safevi seferleri. * Doktora öğrencisi, İstanbul Üniversitesi Sosyal Bilimler Enstitüsü Tarih Bölümü, İstanbul/
Türkiye, emirhanozcelik25@gmail.com, orcid.org/0000-0003-1858-5337 


\title{
Cafer Pashas in Persian Border: The Protection of the Province of Tabriz and Shirvan (1583-1591)
}

\begin{abstract}
The Ottoman-Safavid war of 1578-1590 was the scene of many combat and sieges. During these campaigns, the Ottoman armies managed to conquer important cities such as Shirvan (1583) and Tabriz (1585). Since the campaigns continued and the Ottoman gains were not yet official approved, these conquered regions had to be preserved and ruled by two namesake pashas who were destined to lay the foundations of Ottoman rule in Shirvan and Tabriz. Emektar Cafer Pasha in Shirvan and Hadım Cafer Pasha in Tabriz ensured the settlement of the Ottoman administration and the establishment of a military order in these new conquered province while they were struggling with many troubles and difficulties. The experiences and achievements of these two statesmen in Persian border have an important place in the history of the Safavid campaigns. In this article, the activities of Cafer Pashas are going to be examined and in a correct storyline will be narrated.
\end{abstract}

Keywords: Emektar Cafer Pasha, Hadım Cafer Pasha, Shirvan, Tabriz, Safavid campaigns. 


\section{Giriş}

Bu çalışmada 1578-1590 Safevi savaşlarında boy göstermiş iki adaş devlet adamının hayatı ve tecrübeleri konu edilecektir. Acem seferleri esnasında Şirvan muhafazasında görev yapan Emektar Cafer Paşa (1583-1588) ve Tebriz muhafazasında bulunan Hadım Cafer Paşa (1585-1591) bu bölgelerde Osmanlı hakimiyetinin yerleşmesinde mühim rol oynamıştır. Bu nedenle hayatlarının belirli bir sürelerini harcadıkları Demirkapı, Şirvan ve Tebriz gibi Osmanlılar tarafindan yeni fethedilmiş şehir ve eyaletlerde idarî ve askerî faaliyetlerini incelemek hem Osmanl1-Safevi savaşları hem de bölge tarihi için ayrı bir önem taşımaktadır. Farklı kariyer ve tecrübelere sahip olan Cafer Paşaların Safevi serhaddinde yaşadıkları, Osmanlıların o zamana kadar hakimiyetini sürdüremediği bu bölgelerde, idari düzenin kurulmasında yaşanan benzer zorlukları gözlemlemeye de firsat tanıyacaktır.

\section{8-1590 Osmanlı-Safevi Savaşları ve Üç Farklı Cafer Paşa'nın Hikâyesi}

1578'de Osmanlı Devleti'nin Safevilere savaş ilan etmesiyle başlayan ve yaklaşık on iki sene devam eden uzan mücadele kazançlar göz önüne alındığında Osmanlılar lehine tamamlanmıştır. Düzenlenen ilk seferde Serdar Lala Mustafa Paşa Tiflis ile Şirvan'ı ele geçirmiş ve Gürcistan bölgesini itaat altına alabilmiştir. Selefleri Koca Sinan Paşa ve Ferhad Paşa'nın seferleri aslında fethedilen bölgelerdeki Osmanlı varlığını pekiştirmeye yöneliktir. 1580-1583 yılları arasında Şirvan-Şemahı-Ereş-Demirkapı hattında üstün birlikleriyle saldırıya geçen Safevilere karşı muzafferane başarılar elde eden Özdemiroğlu Osman Paşa, serdarların işini kolaylaştırmıştır. Zaferleri sayesinde serdarlık ve sadrazamlığa terfi eden Osman Paşa'nın 1585'de idare ettiği sefer ise, Osmanlı yayılmasının yönünü değiştirmiştir. Serdâr-1 ekrem Osman Paşa Safevilerin önemli şehirlerinden Tebriz'i fethetmiş fakat sefer sonunda hayatını kaybetmiştir. Yerine geçen ve ikinci defa serdarlık yapan Ferhad Paşa düzenlediği ilk seferde Revan'1 ele geçirmeyi başarmıştır. Bir sonraki seferinde ise, Revan'ın doğusunda bulunan Gence'yi de fethetmiştir. Bu seferler sayesinde, Osmanlı Devleti Şirvan, Gence, Tebriz hattını hakimiyetine katmıştır. Önemli şehirlerini kaybederek barış yapmak zorunda kalan Safeviler, 1590'da imzaladıkları sulh ile Osmanlıların savaş boyunca fethettiği bölge ve şehirleri resmen tanımıştır. ${ }^{1}$

1 Savaşlar için bkz. Bekir Kütükoğlu, Osmanll-İran Siyâsî Münasebetleri (15781612-), İstanbul, İstanbul Fetih Cemiyeti, 1993; Rudi Matthee, "The Ottoman-Safavid War of 986-998/157890: Motives and Causes", International Journal of Turkish Studies, cilt 20, say1 1-2, 2014, s. 1-20. 
Emektar Cafer Paşa ile Hadım Cafer Paşa'nın Acem seferlerine katılımları ve katkıları farklı bir şekilde olmuştur. Bu konunun detaylarına geçmeden önce aynı dönemde yaşayan üç farklı Cafer Paşa'nın kimlik ve kariyerlerini detaylandırmak gerekir. Ayrı dönemde yaşamaları ve benzer kariyerlerinden dolayı bu üç paşa birbirine kolayca karıştırabilmektedir. Bu meyanda, savaşlar başladığında Anadolu Beylerbeyi olan ve Serdar Lala Mustafa Paşa'nın ikinci Acem seferinde boy gösteren Cafer Paşa bahsedilmesi gereken ilk isimdir. Anadolu eyaletine mutasarrıf olmasına rağmen, alınan karar gereği Cafer Paşa 1578 yılındaki ilk sefere katılmamıştır. Bu durum Çıldır Savaşı'nı Osmanlıların kaybettiğine yönelik başkente ulaşan yanlış bilgiler üzerine değişmiştir. Eylül 1578 'de Erzurum muhafazası için eyaletinde mevcut sancak beyleri ve askerlerle derhal yola çıkması emredilmiştir. Ekim ayına gelindiğinde topladığı askerlerle harekete geçmesine rağmen, şiddetli kış ilerlemesine mani olmuş ve Kütahya'ya geri dönmek zorunda kalmıştır. Kendisinden bir sonraki sene düzenlenecek sefere hazırlanması istenmiştir. ${ }^{2}$

Hazırlıklarını tamamlayan Cafer Paşa, ikinci Acem seferine katılmıştır. Serdar Lala Mustafa Paşa söz konusu sefer boyunca düşman kuvvetlerine karşı ciddi bir harekât düzenlememiş veya fütuhat yapmamıştır. Vaktinin ekseriyetini Kars kalesinin inşasına harcanmıştır. Bunun dışında Tifflis'e yardım ordusu göndermiş ve Revan bölgesine ordugâhtaki muhtelif beylerbeylerinin katılımıyla yağma saldırısı düzenlemiştir. Askerî faaliyetlerin sınırlı kalmasına karşın Cafer Paşa kendini göstermeyi başarmıştır. Haziran 1579 'da Kars kalesinde serdar tarafından tevdi edilen iç kale tamiratını tamamlamıştır. Maiyetindeki beylerin verimli çalışmaları sayesinde inşaat işleri hızlı bitirilmişsir. Hatta Cafer Paşa, Lala Mustafa Paşa adına bir cami yaptırmış ve bu sayede serdarın da takdirini kazanmıştır. ${ }^{3}$ Paşa, daha sonra Tiflis kalesine asker ve teçhizat ulaştırmak maksadıyla yapılan ve başından itibaren oldukça zorlu geçen bir göreve katılmıştır. Sokullu-zâde Hasan Paşa'nın önderliğinde başlayan yürüyüşte düşman tehlikesinden dolayı askerler bir müddet sonra yola devam etmek istememiştir. Ancak, Cafer Paşa muhalif askerlerle konuşarak onları Tiflis'e giden yardımların teslim edilmesine ikna etmiştir. ${ }^{4}$ Tiflis'ten döndükten sonra bu defa kendisinin başbuğ atandiğı ve birçok beylerbeyinin iştirak ettiği bir ordu ile Gence ve Revan civarını yağma-

2 Cafer Paşa'ya sefere katılmasını bildiren hükümler için bkz. Cumhurbaşkanlığı Devlet Arşivleri (BOA), Mühimme Defteri (MD), 32, hk. 411, 435, 448, 468.

3 Rahîmîzâde İbrahim Harîmî, Zafernâme-i Sultan Murad Han, İstanbul Üniversitesi Kütüphanesi Tarih Yazmaları Nr. 2372, vr. 45a-45b; Gelibolulu Mustafa Âlî, Nusret-nâme, haz. Mustafa Eravc1, Ankara, TTK, 2014, s. 258-259.

4 Harîmî, Zafernâme-i Sultan Murad Han, vr. 48b-50b; Âlî, Nusret-nâme, s. 242-243. 
layarak tahrip etmiştir (Ekim 1579). ${ }^{5}$ Seferin bütün mühim faaliyetlerinde varlık göstermesi sayesinde mevkiini koruyan Cafer Paşa, ertesi yıl yeni serdar Koca Sinan Paşa'nın seferine de katılmıştır. ${ }^{6}$ Öte yandan Safevilerin barış teklif etmesi üzerine bu sefer boyunca kayda değer hiçbir askerî harekât gerçekleştirilmemiştir. Sefer sonlandırılınca, Cafer Paşa İstanbul'a dönmüş ve Sultan III. Murad'ın oğlu Şehzade Mehmed için tertip ettiği sünnet dügününe katılmıştır (1582). ${ }^{7}$

Günümüz tarihçileri Cafer Paşa'nın bundan sonraki görev yeri ve hayatı hakkında bazı hususlarda yanılgıya düşmüştür. Tekrar başlayan seferlerde, Trablusşam Beylerbeyi olarak görev yapan ve sonrasında Tebriz muhafazasına tayin edilen Hadım Cafer Paşa ile Anadolu Beylerbeyi Cafer Paşa'nın aynı kişi olduğu zannedilmiştir. ${ }^{8}$ Anadolu Beylerbeyi Cafer Paşa 1583'te Ferhad Paşa'nın serdarlık yaptığ Acem seferinden önce Rumeli eyaletine tayin edilmiştir (Aralık 1582). ${ }^{9}$ Daha sonra vezaretle Bender'e gönderilmiş ve Kazaklar üzerine sefer düzenlemiştir. Buradaki mücadelelerinden sonra Cafer Paşa 1584'te İstanbul'a dönmüştür. Vezir rütbesiyle başkentte kalan ve başka makama getirilmeyen Paşa birkaç sene sonra vefat etmiştir (1587). ${ }^{10}$ Ayrıca Cafer Paşa'nın Anadolu Beylerbeyi olduğu dönemde oğluna ulufe verildiğine dair kayıt bulunmaktadır. ${ }^{11}$ Böylece Safevi savaşları sırasında Anadolu ve Rumeli valiliklerini deruhte eden Cafer Paşa'nın hadım olmadığı da açıklık kazanır.

5 Harîmî, Zafernâme-i Sultan Murad Han., vr. 50b-52b; Selânikî Mustafa Efendi, Tarih-i Selânikî, haz. Mehmed İpşirli, c. I, Ankara, TTK, 1999, s. 124.

6 İsmail Hakkı Aksoyak, "Gelibolulu Mustafa Âlî: Fursatnâme”, Akademik Dil ve Edebiyat Dergisi, cilt 1, say1 3, 2019, s. 186.

7 Selânikî, a.g.e., c. I, s. 134-135.

8 Safevi savaşları hakkında yazan, dönemin çağdaş tarihlerini transkript edip indeks hazırlayan veya çalışmalarında savaştan bahsedenlerin aynı yanılgıya düştüğü fark edilmektedir. Örneğin bkz. Kütükoğlu, a.g.e., s. 34, 49 krş. s. 160, 161, 165.

9 Selânikî, a.g.e., c. I, s. 138; Şubat 1583 tarihli Erzurum beylerbeyine gönderilen bir hükümde sabıka Anadolu ve hala Rumeli beylerbeyi olan Cafer Paşa'nın Bayburt'ta kalan cephanesinin gönderilmesi istenilir. Bkz. BOA, $M D, 48$, hk. 829.

10 Selânikî, a.g.e., c. I, s. 138, 140, 148, 178-79; Ekim 1583- Ağustos 1584 arasında Cafer Paşa'nın Bender muhafazası ve mücadelelerine dair gönderilen hükümler için bkz. BOA, $M D$, 52, hk. 181, 274, 324, 331, 484, 568, 768, 769, 775, 823; MD, 53, hk. 271, 336; Ayrica Koca Sinan Paşa'nın bir telhisinde Rumeli beylerbeyi Cafer Paşa'nın derneğe çıkması ile alakalı durumu padişaha açıkladığı fark edilir bkz. Koca Sinan Paşa'nın Telhisleri, haz. H. Sahillioğlu, İstanbul, IRCICA, 2004, s. 64.

11 Aralık 1573 tarihli hükümden Anadolu Beylerbeyi Cafer Paşa'nın oğlu Hacı Mahmud Bey’e elli akçe ulufe tayin edildiği öğrenilmektedir. Bkz. BOA, MD, 25, hk. 321. 
Demirkap1 ve Şirvan muhafazasına atanan Emektar Cafer Paşa ile Tebriz muhafazasıyla vazifelendirilen Hadım Cafer Paşa'nın hikayelerine geçmeden önce aynı isme sahip Anadolu Beylerbeyi Cafer Paşa'nın Safevi seferlerindeki vazifelerini açıklığa kavuşturmak önemlidir. Çünkü yakın tarihlerde birbirlerine uzak olmayan bölgelerde görevlendirilmeleri sebebiyle farklı paşalar isimleri yüzünden aynı kişi zannedilebilmektedir. Bu tarz bir karışıklık izah edilmediği takdirde diğer Cafer paşalar için de geçerlidir. Çünkü bunlar da Safevi seferlerinde boy göstermeden hemen önce Tunus ve Cezayir'de beylerbeylik yapmıştır. 16. yüzyılda Osmanlı Devleti'nin hakimiyetine girmesinden sonra Tunus, Trablusgarp ve Cezayir eyalet haline getirilmiş ve 'Garp Ocakları' adı verilmiştir. İlk başlarda üç bölge müşterek bir idare tarzına sahip olmuştur. Daha sonra her eyaletin müstakil idarî düzenleri oluşturulmuştur. $\mathrm{Bu}$ yüzden Cezayir için Osmanlı kaynaklarında Cezâyir-i Garp yahut Măgrib-zemin ifadeleri kullanılmaya başlanmıştır. Benzer şekilde Tunus da eyalet haline getirilmiş ve ayrı bir beylerbeyi idaresine tevdi edilmiştir. ${ }^{12}$ Emektar ve Hadım Cafer Paşalar neredeyse aynı zaman aralığında Tunus ve Cezayir beylerbeyliği yaptıkları için bu bölgelerin iki ayrı eyalet halinde idare edildiğini belirtmek gerekir. Böylece memuriyetleri kesişen paşaların kimliklerinde hataya düşmenin önüne geçilebilir.

\section{Özdemiroğlu Osman Paşa'dan Emektar Cafer Paşa'ya Demirkapı Muhafazası}

Savaşlar, Osmanlı paşaları için mansıp kazanma veya terfi etme firsatları sunar. Seferlerde gösterdikleri başarılar veya güçlü kapıları olması kariyer çizgilerini şekillendirmiştir. ${ }^{13}$ Örneğin, Acem seferleri Özdemiroğlu Osman Paşa için bu tarz bir yükseliş hikayesi sağlamıştır. Paşa'nın hayatının ilk dönemi babası Özdemir Paşa'nın görev yerleri ve siyasi kariyerinden etkilenmiştir. Habeşistan ve Yemen fetihlerinin mimarı olan babasının sayesinde uzun müddet Habeş ve Yemen eyaletlerinin idaresiyle görevlendirilmiştir. Bölgeye aşinalığı dolayısıyla 1568 yılında Yemen'de başlayan isyanların bastırılmasında Serdar Koca Sinan Paşa

12 Cezayir, Trablusgarp ve Tunus'un idari yapıları ile alakalı bkz. İdris Bostan, "Cezayir-i Bahr-i Sefid Eyaletinin Kuruluşu (1534)", Tarih Dergisi, sayı 38, 2002-2003, s. 68-75; Mustafa Eravc1, "Mühimme Defterlerine Göre Osmanlı Cezayir-i Garp", Gazi Akademik Bakış, sayı 20, 2017, s. 83-94; Güneş Işıksel, "Le statut de la Tripolitaine dans l'espace politique ottoman au xvie siècle”, Hypothèses, say1 16, 2013, s. 375-382; Emrah Naki, "1574 Tunus Seferi Üzerine Yeni Bir Bakış”, OTAM, sayı 40, 2016, s. 129-144; Atilla Çetin, "Garp Ocakları”, Türkiye Diyanet Vakfi İslam Ansiklopedisi, cilt 13, 1996, s. 382-383.

13 Paşa kapılarının mansıp kazanmadan önemi ve beylerbeyi makamının evrimine dair genel bir değerlendirme için bkz. Metin Kunt, The Sultan's Servants: The Transformation of Ottoman Provincial Government, 1550-1650, New York, Columbia University Press, 1983, s. 77-93. 
ile ortak hareket etmiştir. Fakat bu seferler sırasında Sinan Paşa ile ters düşünce azledilmiş ve II. Selim tarafından İstanbul'a çağırılmıştır. Lala Mustafa Paşa'nın başkentte kendisini kollaması sayesinde 1573'te Lahsa beylerbeyliğine atanmıştır. Lahsa'dan sonra Basra ve Diyarbakır eyaletlerini idare etmiş fakat Acem seferlerinden kısa bir süre önce mazul duruma düşmüştür. ${ }^{14}$ Osman Paşa'nın doğu seferlerini tekrar makam elde etmek için bir fırsat gördüğü anlaşılmaktadır. Öyle ki, Mart 1578 'de III. Murad'a mektup gönderip şecaati ve şehâmetinden bahsetmiştir. Paşanın savaşçı karakterini öne çıkarma çabası semeresini vermiş; III. Murad cevabında kapı askerini hazırlayıp Serdar Lala Mustafa Paşa'nın komutası altına girmesini emretmiştir. ${ }^{15}$ Serdar ile arasında iyi münasebet de hesaba katıld1ğında Osman Paşa'nın seferden kazançlı çıkma hesapları yaptığı düşünülebilir. ${ }^{16}$

Bin kadar silahşör ve cündî çakerleri ile orduya katılan Osman Paşa seferin başından itibaren askerî sahadaki yetkinliğini kanıtlamıştır. Ani gelişen Çıldır Savaşı'nda askerleri ile Safevi kuvvetlerini bozarak Osmanlıların galip ayrılmasına büyük katkı sağlamıştır. Akabinde serdarın görevlendirmesi ile Tiflis'i ele geçirmiştir. Gürcistan meliklerinin itaat etmesinin ardından Şirvan kolayca fethedildiği an Osman Paşa'nın mazul hali de son bulmuştur. Şirvan muhafazasında kalmayı kabul eden paşaya vezaret verilmiştir. Ana ordunun bölgeden çekilmesi ile Osman Paşa, düşük rütbeli beyler ve mütevazı birlikleriyle vazifesine başlamıştır. Emrindeki az kuvvete rağmen saldırılar yapmış ve Azerbaycan dolaylarında bulunan şehirleri fethetmeye yönelmiştir. Ereş ve Şemahı'ya zorlanmadan hakim olsa dahi sayıca üstün Safevi birliklerinin karşılık vermeye başlaması ilerlemesini durdurmuştur. Düşman karşısında aldığ1 seri mağlubiyetler Şirvan'1 terk edip Demirkapı'ya kadar çekilmesine neden olmuştur. Ancak, Ekim 1579'da Kırım Hanı Mehmed Giray'ın büyük bir ordu eşliğinde Osman Paşa'nın yardımına gelmesi ile vaziyeti bir süre düzelmiştir. Tekrar Şirvan ve Şemahı'ya giren Osmanlı-Tatar birlikleri Bakü’yü de kontrol altına almıştır. Lakin Serdar Mustafa Paşa'nın Osman Paşa'ya katılıp müşterek bir saldırı yapma fikrinden cayması K1-

14 Mustafa Karanfil, "Hârimi'nin Zafernâme ve Gonca’sına Göre Özdemiroğlu Osman Paşa”, (Yayınlanmamış Yüksek Lisans Tezi), İstanbul Üniversitesi, İstanbul, 1998, s. 3-9; Reyhan Şahin Allahverdi, "Özdemiroğlu Osman Paşa ve Dönemi (15271585-)", (Yayınlanmamış Doktora Tezi), Mimar Sinan Güzel Sanatlar Üniversitesi, İstanbul, 2012, s. 18-65.

15 BOA, $M D$, 32, hk. 228; Mustafa Âlî de Osman Paşa'yı savaşa davet eden bir mektup paylaşır bkz. Âlî, Nusret-nâme, s. 43-45.

16 Lala Mustafa Paşa ile Özdemiroğlu Osman Paşa arasında Yemen hadiselerinden sonra İstanbul'da kurdukları ilişki için bkz. Mustafa Âlî, Künhü'l-Ahbâr, Berlin Staatsbibliothek Orientalische Handschriften, Hs. or. 1090, vr. 439a-b; Hatta aralarındaki ilişki dönemin Fransız elçisinin raporuna dahi yansımıştır bkz. Ernest Charrière, Négociations de la France dans le Levant ou Correspondance, Mémoires et Actes Diplomatiques, Paris, 1853, c. III, s. 82. 
rım Hanı'nın bölgeyi terk etmesiyle sonuçlanmıştır. Geride kalan Tatar hanzade ve askerlerinin de zamanla geri çekilmesi yahut Safevi birliklerine yenilmesiyle, Osman Paşa'yı yine kendi birlikleriyle baş başa bırakmıştır. Zamanla yanındaki askerlerin hayat şartları ve imkânsızlıklardan dolayı şikayetleri artmış, hatta bir kısmı firara başlamıştır. Safevi komutanları Osman Paşa'nın zayıf halinden yararlanmakta gecikmemiş ve kendisini Demirkapı'da sıkıştırmayı başarmıştır. ${ }^{17}$

1581 senesinden itibaren Osman Paşa'nın yaşadığı sıkıntılara bağlı olarak askerî ihtiyaç talepleri çeşitlenmiş ve bunları hükümete iletme sıklığı artmıştır. Keza başkente gelen haberlerin bazılarına göre Şirvan muhafazasında bulunması gereken dört yüze yakın yeniçeri Paşa'nın yanından ayrılmıştır. ${ }^{18}$ Asker kaybına karş11ık Osman Paşa atlı asker talep etmiştir. Bunun üzerine III. Murad, serdarına bir iki beylerbeyi eşliğinde ulufeli süvarileri Şirvan muhafazasına irsal etmesi için emir göndermiştir. ${ }^{19}$ Şirvan'da kalan yeniçerilere ise Osman Paşa'ya itaat etmeleri emredilmiştir. İhtiyaçları için gerekli hazinenin yollanacağı taahhüt edilmiştir. ${ }^{20}$ Birkaç kez Osman Paşa'nın yanında iyi hizmet eden askerlerin mevkileri arttırılmış ve bu şekilde muhtemelen mevcut askerlerin morali canlı tutulmaya çalış1lmıştır. ${ }^{21}$ Ekim 1582 'de gönderilen hayli uzun bir hükümde Osman Paşa'dan Şirvan eyaletini, askerini, halkını koruması; her türlü tedbiri alıp düşman karşısında bütün çabasıyla mücadele etmesi istenmiştir İstanbul'a gelme fikrini aklından çıkarması da ayrıca vurgulanmıştır. Paşaya asker talebinin birçok beylerbeyine ulaştırıldığ 1 ve hepsinin askerî yardım için hazırlandığı da bildirilmiş; ve kendisinin bölgede kimseye sıfırdan tımar ve zeamet vermemesi tembih

17 Osman Paşa'nın seferleri için müstakil eserler kaleme alınmıştır. Safevi sınırındaki savaşlarının detayları için bkz. Âsafî Dal Mehmed Çelebi, Şecâ'atnâme, haz. Abdülkadir Özcan, İstanbul, Çamlıca Basım Yayın, 2007, vr. 15a-151a; Yunus Zeyrek, Târîh-i Osman Paşa, Ankara, Kültür Bakanlığı, 2001, s. 15-57; Ebubekir bin Abdullah, Tevârih-i Osman Paşa, Bibliothèque Nationale de France Département des manuscrits, Turc 123, vr. 20b-69b; ayrıca bkz. Kütükoğlu, a.g.e., s. 95-97, 102-107.

18 Yeniçeri kethüdasına gönderilen hükümde icazet aldığını iddia ederek Osman Paşa'nın yanından ayrılan kapı kullarının akıbetlerini öğrenmesini ve sorunu gidermesi istenir bkz. BOA, $M D$, 47, hk. 260; Başka bir hükümden icazet almadan ulufe bahanesiyle Şirvan'1 terk edip İstanbul'a gelen bölük halkından kimselere ulufelerinin verilmediği ve tekrar Şirvan'a gönderildiği öğrenilir bkz. BOA, MD, 44, hk. 144; Osman Paşa'yı terk eden askerlerden Âsafî de bahseder ve bu gelişmeye münhasır bir minyatürde bulunur bkz. Âsafî, a.g.e., vr. 105b-110a.

19 BOA, $M D$, 44, hk. 54, 13 Safer 989; Benzer bir talebi karşılaması için Kefe beylerbeyine de hüküm gönderilmiştir bkz. BOA, MD, 42, hk. 190, 19 Cemaziyülevvel 989.

20 BOA, $M D, 42$, hk. 643, 23 Muharrem 989.

21 BOA, MD, 44, hk. 57, 60, 10 Rebiyülevvel 989. 
edilmiştir. ${ }^{22}$ Özdemiroğlu Osman Paşa'nın Şirvan'dan ayrılmaması için alınan en geniş ölçekli önlem ise Kefe sancakbeyi bayrağı altında gönderilen destek ordusudur. Emektar Cafer Paşa'nın Safevi serhaddine gitmesine vesile olan bu gelişme zamanla Şirvan'ın kaderini de biçimlendirecektir.

\section{Tunus'tan Şirvan'a Hızlı Geçiş: Kefe Sancakbeyi Cafer Paşa}

Şirvan'a gidecek destek ordusuna başbuğ tayin edilirken "emektar" sıfatının kullanılması Cafer Paşa'nın 1580lere doğru pirliğe eriştiğine işaret eder. Yaşının hayli ilerlediği aşikar olan Paşa'nın kariyerinin detaylarını açıklamak maalesef pek kolay değildir. Aynı isimli birçok bey ve paşanın yakın zaman aralıklarında memuriyetlerine dair bilgiler Emektar Cafer Paşa'nın aralarından hangisi olduğunu tespit etmeyi güçleştirmektedir. Zira mevzubahis Cafer Paşa'ya atfedilecek hususiyetleri ifade eden kayıtlar mevcut değildir. Yine de Şirvan muhafazas1 gibi tecrübe ve başarı gerektiren bir vazife için seçilmesinin de etkisiyle kendisinin kariyeri hakkında kısmen sarih malumatımız vardır. Kefe'ye atanmadan önce Tunus'ta görev aldığına dair kesin bilgiler bulunması önemli başka bir ipucu sağlar. Bu listeye daha önce Kefe ve Temeşvar eyaletlerinde yöneticilik yaptığ ve Tunus'a tayin olmadan İstanbul'da mülâzamette bulunduğu eklenebilir.

Emektar Cafer Paşa Nisan 1568'de terfi ederek Kefe sancağından Temeşvar beylerbeyliğine atanmıştır. Valiliği boyunca özellikle Erdel'de meydana gelen hadiselere doğrudan müdahil olmuştur. Mesela isyan edip Erdel eyaletine saldıran asilere karşı mücadele etmiş ve galip gelmiştir. Erdel sınırında düşmanın harekâtını yakinen izlemiştir. Hatta sınır hattında bulunan kalelerden birini de fethetmiştir. Görevi kapsamında Temeşvar eyaleti genelinde idarî, askerî ve ekonomik muhtelif meselelerle ilgilenmiştir. ${ }^{23}$ Yaklaşık on yıl aynı görevde kalmas1 Sultan'ın, Cafer Paşa'nın buradaki faaliyet ve idaresinde memnun kaldığının göstergesi olabilir. ${ }^{24}$ Temeşvar valiliğinden sonra Cafer Paşa'ya öncelikle Acem seferlerinde görev verilmek istenmiştir. Halihazırda batı serhaddinde kayda değer bir askerî tecrübe kazanan Paşa, Şam muhafazasına getirilmiştir. Görevi ge-

22 Bazı noktalarda tehditkar bir tona sahip hükümde Osman Paşa'nın rahatsızlıklarını öne çıkarıp gevşemesine müsaade edilmemek istendiği anlaşılmaktadır bkz. BOA, $M D$, 44, hk. 189.

23 Cafer Paşa'ya Temeşvar'a atandığını ilan eden hüküm için bkz. BOA, MD, 7, hk. 2736, 16 Şevval 975; Vazifesi boyunca gerçekleşen askerî hadiseler ve paşanın bu meyanda faaliyetleri ile ilgili kayıtlara yansıyan bilgiler için örneğin bkz. BOA, $M D, 14$, hk. 35, 131, 1195, 1581, 1582, 1603; BOA, A. DVN. MHM. d. 932, s. 7; BOA, MAD. d. 136, s. 2-9.

24 Temeşvar'a Cafer Paşa'dan sonra yapılan sonraki beylerbeyi atamasının tarihi Haziran 1577'dir bkz. Bilgin Aydın - Rıfat Günalan, "Ruus Defterlerine Göre XVI. Yüzyılda Osmanlı Eyalet Teşkilatı ve Gelişimi”, Osmanlı Araştırmaları, sayı 38, 2011, s. 145. 
reği Erzurum'da bulunan Şam beylerbeyi mahalline dönene kadar Cafer Paşa Şam'ın idaresini üstlenecektir. Ancak, beylerbeyi kısa bir süre sonra Şam'a dönünce paşanın tayini de iptal edilmiştir. Bunun üzerine Cafer Paşa mülâzemet için başkente çağrılmıştır (Aralık 1578). ${ }^{25}$

Cafer Paşa'nın mazuliyeti Temmuz 1579 'da Tunus'a tayin edilince sonlanmıştır. ${ }^{26}$ Kısa süren görevi sırasında bölgedeki kapıkulunun reaya aleyhine ihdas ettikleri kanun dışı bazı uygulamalar gibi sıkıntıları çözüme kavuşturması beklenmiştir. ${ }^{27}$ Ölen ve kaybolan yeniçerilerin tüfeklerinin devlet adına zapt etmek de bu sırada ilgilendiği diğer bir konu olmuştur. Ancak, Cafer Paşa'nın bazı faaliyetlerinden hükümetin hoşnut olmadığı azlinden sonraki bir gelişmeden öğrenilmektedir. Paşa'nın Havass-1 hümâyûna ait arazileri, timar ve zeamet suretiyle dağıtması payitahtta eleştirilmiş ve yeni beylerbeyinden bu durumu düzeltmesi istenmiştir. ${ }^{28}$ Diğer taraftan, Cafer Paşa'nın Tunus'tan azledildikten sonra Trablusşam'a atandığına dair bir kayıt vardır. ${ }^{29}$ Fakat bu vazifeyi icra edip etmediği esasında bir muammadır. Kesin olan bir husus sabık Tunus beylerbeyi olarak Mayıs 1581'de İstanbul'a gelmesidir. Cafer Paşa'nın başkente ulaşmasına yardımcı olmaları için birçok devlet adamına hüküm gönderilmiştir. ${ }^{30}$ Kendisinin İstanbul'a varmasından kısa bir süre önce Kefe üzerinden Şirvan'daki Osman Paşa'ya gönderilecek destek ordusunun hazırlıkları başlamıştır.

Nisan 1581 'den itibaren, Rumeli beylerbeyinin başbuğ olduğu ve muhtelif eyalet ve sancak beylerinin davet edildiği destek ordusunun Kefe'de toplanmas1na karar verilmişti. Bosna, Temeşvar, ve Rumeli beylerbeylerinden eyaletlerinin timar ve zeamet sahiplerini hazırlayıp Kefe'ye hareket etmeleri istenmiştir. Rum, Kastamonu ve Zulkadriye beylerine de aynı minvalde emirler gönderilmişti. ${ }^{31} \mathrm{Fa}$ kat Demirkapu seferi için hazırlıklar oldukça uzamış ve sonraki seneye sarkmıştır. Mart 1582'de Cafer Paşa Kefe beylerbeyliğine atandığında Şirvan'a gidecek bir ordu henüz ortada yoktu. ${ }^{32} \mathrm{Bu}$ noktada, Cafer Paşa'nın Kefe'ye tayini ile ayrıca destek birliklerinin serdarı da seçildiği belirtilmelidir. Geciken hazırlıkların

25 BOA, $M D, 32$, hk. 451, 452, 453, 473, 827.

26 Aydın - Günalan, a.g.m., s. 157.

27 BOA, $M D, 40$, hk. 148, 9 Ramazan 987.

28 Yeniçerilerden tüfenk toplama fikri azlinden sonra gündeme gelmiştir bkz. BOA, $M D, 42$, hk. 459, 23 Rebiyülevvel 989; BOA, MD, 40, hk. 132.

29 Aydın - Günalan, a.g.m, s. 149.

30 BOA, $M D$, 42, hk. 770, 771, 3 Rebiyülevvel 989; 805, 27 Cemaziyülevvel 989.

31 BOA, $M D, 44$, hk. 80, 81, 93, 98; $M D, 47$, hk. 780.

32 Cafer Paşa Kefe beylerbeyliğine atanmasıyla alakalı bkz. BOA, MD, 47, hk. 13; Aydın - Günalan, a.g.m, s. 108 . 
tamamlanması ve orduyu idare etmesi için güvenilir ve tecrübeli birine duyulan ihtiyaç dolayısıyla hükümetin onu tercih ettiği ifade edilebilir. Yahut bizzat Cafer Paşa'nın vazifeyi üstlenme teklifinde bulunduğu bir ihtimal olarak düşünülebilir. ${ }^{33}$ Hakkında kullanılan ihtiyar ve emektar sıfatları tecrübesine binaen serdar olarak atanmasındaki gerçek neden olabilir.

Emektar Cafer Paşa'nın Kefe beylerbeyi ve Şirvan serdarı olmasını müteakiben Rumeli ve Rum eyaleti beylerine tekrar bir seri hüküm gönderilir. Rumeli Beylerbeyi Mehmed Paşa'nın yerine Cafer Paşa'nın vazifelendirildiğine değinildikten sonra, ilgili eyalet ve sancak beylerine bölgelerindeki kuvvetlerle Kefe'ye varmaları emredilir. Önceki seneden farklı olarak Bosna ve Temeşvar beylerbeyi ile Zulkadriye beyi bu defa davet edilmemiştir. Mart-Nisan 1582'de Rumeli beylerbeyi yanında Niğbolu, Silistre, Köstendil beyleri, Rumeli'nin sağ ve sol sipahileri sefere çağrılmıştır. ${ }^{34}$ Rum beylerbeyleriyle Kastamonu ve Çemişgezek beylerinden de Sinop ve Samsun iskelelerinden Kefe'ye geçip Cafer Paşa'ya katılmaları istenmiştir. ${ }^{35}$ Fakat zaman kaybına neden olacağı için sonradan Rum'dan gelecek kuvvetlere Kefe'ye geçmemeleri ve karadan Şirvan'a doğru gitmeleri bildirilmiştir. ${ }^{36}$ Haziran 1582 'de Sincar beyi Budak Bey'e ise altı bin sipahi ve otuz yük akçe ile başbuğ olup acilen Osman Paşa'nın yanına gitmesi emredilmiştir. ${ }^{37}$ Hazırlıklar hakkında Osman Paşa'ya verilen bilgiye göre mezkûr eyalet ve sancak askerlerine ek olarak Cafer Paşa'nın ordusuna üç bin yeniçeri, altı yüz silahdar ve Sivas timar ve zuamâsı da katılmıştır. ${ }^{38}$

Üç buçuk ay içinde bütün hazırlıklar tamamlayan Cafer Paşa, A ğustos 1582'de Kefe'den yola çıkar. Mustafa Âlî’nin yolculukla alakalı verdiği detaylara bakılırsa Kerç boğazından zahmetle on beş günde geçen ordu iki konak sonra Kuban nehrine varmıştır. Çerkezlerin sallarını kullanmak için ücretler ödenmiş ve nehir aşılmıştır. Gümrüğü adındaki vilayete varıldığında paraya değer vermeyen farklı bir Çerkez halkına karşı Osmanlı askerleri mallarını korumak zorunda kalmıştır.

33 Mesele Cafer Paşa'dan önce sabıka Trablusgarp beylerbeyi Haydar Paşa Kefe sancağı beylerbeyi atanması durumunda Şirvan'a kul karındaşı alup gidüp yolda lazım olan mühimmât ve arabaların ve bargirlerin kendü yanımdan tedârik idüp bi-inâyeti'llâh-i te 'âlâ emîn ve sâlim ulaşdırayım deŷ̂ uhdesine alduğı pâye-i serîre arz olunup ulûfelerin virmeğe dahî müteahhid olurum hem mevâciblerin virüp hem harçların görüp salim ulaşdıra bunu dahi demiş ve açıça bir teklifte bulunmuştur bkz. Aydın - Günalan, a.g.m., s. 107-108.

34 BOA, $M D, 44$, hk. 104, 105, 106, 107, 108, 112, 117, 125.

35 BOA, $M D, 44$, hk. 110, 113, 116, 124.

36 BOA, $M D, 44$, hk. 185, 01 Şaban 990.

37 BOA, $M D, 44$, hk. 145, 150, 165.

38 BOA, $M D$, 44, hk. 123; Bütün bu hazırlık süreci için ayrıca bkz. Kütükoğlu, a.g.e., s. 126-128. 
Buradan ayrılınca "güvercin yumurtasından büyük" dolu yüzünden pek çok at telef olmuştur. ${ }^{39}$ Kırım sınırlarındaki uçsuz bucaksız Heyhât Sahrası'na varıld1ğında ise hayli ilginç bir hadise yaşanmıştır. Âsafî’nin bahsettiği olaya göre dağın tepenin olmadığı bu geniş Kırım ovalarını çeşitli türlerde ceylanlar istila etmiştir. Cafer Paşa'nın ordusundaki askerler kolay kolay okla vurulamayan ama insanlardan da kaçmayan ceylanları zaman zaman avlamıştır. Yine askerlerin avda olduğu bir gün hücuma geçmiş süvari ordusunu andıran sesler duyulur. Gürcü ve Rusların sık sık gerçekleştirdiği pusulardan biri olma ihtimalini aklına getiren askerler büyük bir şaşkınlık ve tedirginlik yaşar. Hızlıca savaş pozisyonu alan Osmanlı birlikleri düşman askeri beklerken büyük bir karaca sürüsü ile karşılaşır. Saflar halinde adeta bir ordu adabında hareket eden karacalardan korktuklarını anlayan Osmanlı askerleri yine de durumu firsat telakki eder. Üzerlerine gelen bu büyük sürüye saldıran askerler bu sayede bir savaş talimi gerçekleştirmiş olur. ${ }^{40}$ Şirvan yolunda yaşanan bu garip hadise, Cafer Paşa adına serhad bölgesinin muhtelif tehlikelerinden en hafifi sayılabilir. Zira seksen gün süren yolculuğun ardından Şirvan'a ulaşan Osmanlı ordusu çok geçmeden Osman Paşa'nın yanında Safevilere karşı hayli çetin bir savaşa girecektir.

\section{Safeviler Karşısında Büyük Zafer ve Cafer Paşa'nın Şirvan'a Yerleşmesi}

Emektar Cafer Paşa'nın, asker, zahire ve hazine takviyesi sayesinde Demirkapı'da yaşam şartları iyileşirken Osman Paşa da bölgeyi muhafaza etmek için ihtiyacı olan askerî imkânlara erişmiştir. Yaklaşan kış dolayısıyla Safevilerden saldırı beklenmemesi ona fethedilen yerlerde Osmanlı hakimiyetini sağlamlaştırma firsatı tanımıştır. Cafer Paşa da kışın araya girmesiyle Demirkapı'ya muhtelif eyaletlerden gelen askerlerin sıkıntı çekmemesi adına bazı önlemler almıştır. Sofya, Edirne, Kastamonu ve Rumeli'den sefere katılan zuama ve timar erbabının bölgelerinden elde edecekleri gelirin toplanması için görevliler göndermiştir. Demirkapı'ya ulaştırılan gelirler sayesinde bu askerler kış boyunca sıkıntı çekmemiştir. ${ }^{41}$

39 Âlî, Künhü'l-Ahbâr, vr. 530b-531b; ayrıca bkz. Mehmed bin Mehmed er-Rumî, Nuhbetü 't-Tevârîh Ve'l-Ahbâr, Berlin Staatsbibliothek Orientalische Handschriften, Ms. or. fol. 4097, vr. 191a-191b; Mehmed er-Rumî Cafer Paşa'nın yirmi bin askerler Şirvan'a vardığı bilgisini verir.

40 Şecâ'atnâme'de bu hadisenin bir minyatürü de bulunur bkz. vr. 159b-160b.

41 Sofya, Kastamonu, Edirne ve Rumeli sağ kolundaki kadılara Ekim-Ocak 1582 arasında gönderilen hükümlerde Cafer Paşa'nın harçlıkları toplamak için gönderdiği adamlara yardımcı olmaları istenmiştir bkz. BOA, MD, hk. 399, 519, 632, 712. 
Osmanlıların Demirkapı'da vaziyetlerinin düzelmesi ve varlıklarını pekiştirmesi Şemahı ve Dağıstan yöresindeki yerel beyleri tedirgin etmiştir. Beyler tedarikleri görüldükçe sayıları artan Osmanlı ordusunu yenmenin zorlaşacağını ve bunun zamanla kendi mülklerini zarara uğratacağını düşünürler. Kaygılarını paylaşmak üzere, Gence hakimi İmam Kulu Han'a elçiler gönderip onu Osmanlılara karşı harekete geçirmek isterler. Bu maksatla gönderilen elçiler Osman Paşa'ya yardıma gelen Osmanlı askerlerinin sûfîler gibi uzun etek giydiklerini ve nicesinin yarı çıplak halde bulunduğu bilgisini paylaşır. İmam Kulu'nu savaşamayacak durumdaki Osmanlı birliklerine vakit kaybetmeden saldırması için teşvik ederler. Gence hakimi bu çağrıları geri çevirmemiştir. Elli bin askerden müteşekkil bir ordu hazırlamış ve 1583 baharında Osmanlılara karşı harekete geçmiştir. Düşmanın savaşmak için yola çıktı̆̆ını öğrenen Osman Paşa'nın buna göre bir karar vermesi gerekmiştir. Karargahta alınan karar mucibince Silistre ve Köstendil sancakbeyleri Şirvan'a girip Safevilerin öncü birlikleriyle çarpışmıştır. Düşman ilk esnada hezimete uğratılmasına rağmen Silistre sancakbeyi bu esnada ölmüş ve takviyeye gelen askerlerle güç kazanan Safeviler Osmanlı öncü kuvvetlerini bozmuştur. Yenilgiden kaçan Osmanlı askerleri Demirkapı'ya gelince Osman Paşa Safevi ordusu ile meydan savaşı yapmaya karar vermiş ve şehirden ayrılmıştır.

Şirvan'a giren ve Samur Nehri'ni geçip geniş araziye ulaşan Osmanlı ordusu savaş düzeni almaya başlar. Cafer Paşa kapı askeri ve Şirvan'daki Rumeli askerleriyle sol kola yerleşir. Rum beylerbeyi eyalet askerleri ile sağ kolu alırken Osman Paşa da ortada yeniçeriler ve toplarla mevki tutar. Safevi ordusunun da saflara ayrılmasının akabinde dört gün süren bir savaş başlar. İlk gün, öncü birliklerin çatışmalarıyla geçmiştir. İkinci gün Cafer Paşa'nın kolu üzerinden Safevi birlikleri bozulmuştur. Silahdarların da yardımıyla iyice kırılan düşman birliklerini kovalama fırsatı yakalanır. Cafer Paşa ordu düzenini bozacağını düşünerek askerlerini engeller ve takibe müsaade etmez. Üçüncü gün Safevilerin Osmanlı ordusunun arkasına sarkma girişimi önlenmiştir. Dördüncü gün ise Safeviler üç koldan genel saldırıya geçmiş ve Cafer Paşa'nın bulunduğu sol kanadı sarsmıştır. Ancak, Paşa'nın saflarına takviye birlikler gönderilerek düşmanın direnci kırılmıştır. Toparlanan sol kanatla birlikte Osmanlılar karşı saldırı gerçekleştirir. Bu saldırıyla düşmanı bozmaya başlayan Osmanlı ordusu akabinde genel bir hücuma kalkmıştır. Başarılı olan bu son saldırıyla Safeviler nihayet bozguna uğramıştır. Firar eden birliklerini toparlayamayan İmam Kulu Han kaçmak durumunda kalmıştır. Böylelikle savaş Osmanlıların zaferiyle sonuçlanmıştır. ${ }^{42}$

42 Öncü muharebeler ve meydan harbi için bkz. Âsafî, a.g.e., vr. 161b-182a; Zeyrek, a.g.e., s. 58- 
Özdemiroğlu Osman Paşa'nın liderliği ve Cafer Paşa'nın temin ettiği destek ordusunun katkısı ile kazanılan bu zafer, Şirvan'daki Osmanlı hakimiyetini adeta tescil etmiştir. Büyük bir ordu ile yaptıkları saldırının başarısız olması ise Safevilerin bölgeyi geri alma umutlarını kırmıştır. Savaştan hemen sonra, Osman Paşa, Şemahı'ya gidip kalesini tamir ettirmiş ve Köstendil sancakbeyi Şami Mustafa Bey'i buraya beylerbeyi bırakmıştır. Şehrin gerekli askeri ihtiyaçlarını da karşıladıktan sonra Demirkapı'ya dönmüştür. Burada, Osman Paşa İstanbul'a hareket etmeden önce Cafer Paşa ile son kez bir görüşme gerçekleştirmiştir. Demirkapı muhafazasını üstlenmesi karşılığında paşaya vezaret vermiş ve kendisini "Şirvan içre serdar ü vezir" tayin etmiştir. ${ }^{43}$ Cafer Paşa Demirkapı'da kalarak hükümetinde takdirini kazanmıştır. Paşa'ya yazılan ilgili bir hükümde, vazifesini hakkıyla yerine getirdiği için övülmüş ve serhadde sürdürdüğü askerî faaliyetleri dolayısıyla memnuniyet dile getirilmiştir. Serdar Ferhad Paşa ve ondan merkeze ulaşan mektupta da Safevilere karşı galibiyet ve Şemahı'nın inşasının haberleri verilirken bütün bu süreçte gösterdiği hamiyet sebebiyle Cafer Paşa'dan ayrıca sitayişle bahsedilmiştir. Padişah, kendisine "yüzün ak olsun" diye iltifat ederek eyaletin muhafazasını ve bütün askerî önlemleri en iyi şekilde almasını istemiştir (Ağustos 1583). ${ }^{44}$

63; Âlî, Künhü'l-Ahbâr, vr. 531b-534a; Mehmed bin Mehmed Er-Rumî, a.g.e., vr. 193a-195a; Osman Paşa'nın savaşı anlatan bir mektubu için bkz. Abdurrahman Şeref, "Özdemiroğlu Osman Paşa'nın Bir Mektubu”, Türk Tarih Encümeni Mecmuası, sayı 43, 1917, s. 35-41; Kütükoğlu, a.g.e., s. 130-133.

43 Şemahı kalesinin inşası ve Demirkapı'da Cafer Paşa'ya vezaret verilmesi ile alakalı bkz. Âsafî, a.g.e., vr. 183a-184b; Er-Rumî, a.g.e., vr. $195 \mathrm{~b}$.

44 BOA, MD, 51, hk. 64. 


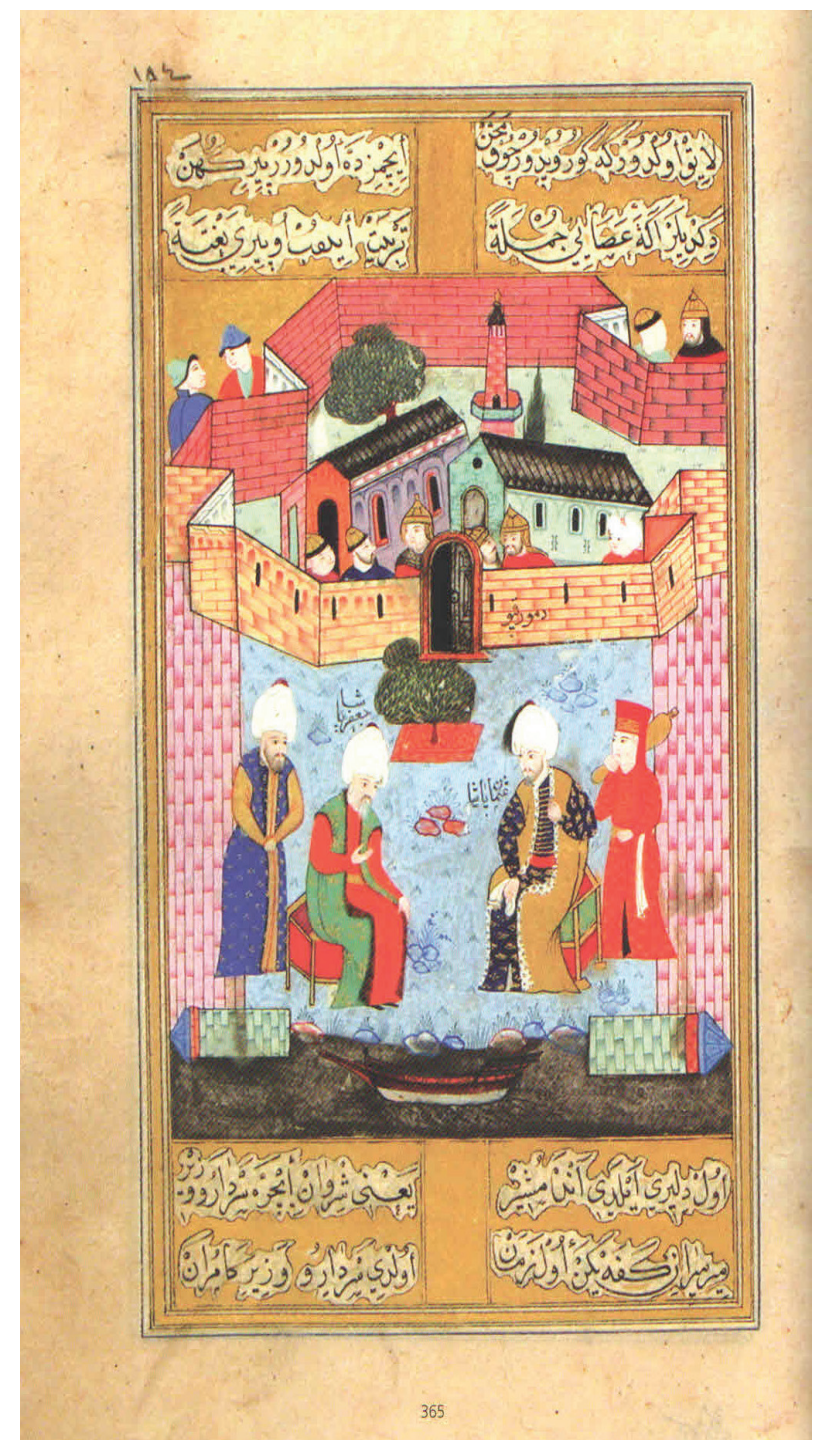

Minyatür 1. Özdemiroğlu Osman Paşa’nın Demirkapı'da Emektar Cafer Paşa ile Görüşmesi, Şecâ' 'atnâme, İÜ Nadir Eserler Kütüphanesi TY, n. 6043, vr. 184a

\section{Emektar Cafer Paşa'nın Demirkapı ve Şirvan'da İlk Yılları}

Demirkapı muhafazasına tayin edilen Emektar Cafer Paşa, vefatına kadar gerek ikamet ettiği şehrin gerekse Şirvan eyaletinin askerî ve idarî işleri ile meşgul olmuştur. Vaktinin çoğunu mesuliyetindeki kalelerin bakımı ve mevcut askerî 
birliklerin ihtiyaçlarını sağlamaya harcamıştır. Vazifede bulunduğu süre boyunca Acem seferleri devam edeceği için henüz Osmanlı hakimiyetinin resmiyet kazanmadığı bu diyarda idarî ve siyasî düzenin temelini atmaya çalışmıştır. Ayrıca Acem seferlerinin serdarları ile irtibatını sürdürmesi gerekmiştir. Seferlerin gidişatına göre askerî sorumluluklarını yerine getirmeye çalışmıştır. Bunun yanında Demirkapı ve Şirvan bölgesinin kısa süreli de olsa Osmanlı yönetimine olan aşinalığ 1 Cafer Paşa'nın işlerini kolaylaştırabilmiştir.

1578 senesinde Serdar Lala Mustafa Paşa başlayan seferlerin ilk hedefi Şirvan olmuştur. Bölgedeki Sünni Müslümanların Safevi yönetimi altında zulüm görmeleri Osmanlı Devleti nazarında savaşın meşru gerekçelerinden biri sayılmıştır. Osmanlı ordusunun Şirvan'a mukavemetsiz girmesini takip eden süreçte gerek Gürcistan gerekse Azerbaycan beldelerinin yerel yöneticileri itaatlerini bildirmek için Serdar Lala Mustafa Paşa'nın huzuruna gelmiştir. Yeni fethedilen Ereş’teki ikameti esnasında serdarla görüşen "Derbend demekle maruf Demirkapı'dan" beş kişilik heyet de artık Osmanlılara tabii olduklarını ilan etmiştir (Ekim 1578). Mustafa Âlî’nin tanımıla “memalik-i Şirvan'da dâhil, mâverâsı bir cânibden Dağıstan'a ülkelerine muttasıl ve bir taraftan Deşt-i Kıpçak vilayetlerine mutavassll" olan Demirkap1 konumu itibariyle önemlidir. Hatta Demirkap1 ahalisi sedd-i İskender' in bekçileri say1lmaktadır. ${ }^{45}$ Sokullu Mehmed Paşa, muhtemelen ölmeden önce kaleme aldığ1 son mektuplarından birinde, Hazar Denizi ve kıyılarına hakim olmayı tasarlamış ve bu tasarıda Demirkapı'ya önemli bir rol biçmiştir. Özdemiroğlu Osman Paşa'nın plan dahilinde hükümete sağladığı bilgilere mektubunda değinen Mehmed Paşa gerekli malzemelerin ulaşmasından sonra Demirkapı'da yapılacak yirmi kadırgayla Hazar Denizi etrafındaki vilayetlerin fethedilebileceğini öğrenmiştir. Sokullu Mehmed Paşa mektubunda gemi yapımı için hangi malzemelere ihtiyaç duyulduğunu Osman Paşa'dan daha detaylı bildirmesini istemiştir. Fakat kısa süre sonra vefat edince Demirkapı merkezli bu teşebbüs sonuçsuz kalmıştır. ${ }^{46}$

Mustafa Âlî’ye göre, Şirvan'da Osmanlı hakimiyetinin tesisinin ardından yapılan idarî düzenlemelerde Derbend bir eyalet haline getirilmiştir. Yedi sancak halinde düzenlenen eyaletin merkezi ve dolayısıyla beylerbeyinin oturağ 1 Demirkapı olmuştur. ${ }^{47}$ Ancak dönemin ruus kayıtlarında Demirkapı'dan bir san-

45 Âlî, Nusret-nâme, s. 158-159.

46 Safvet, "Hazar Denizi'nde Osmanlı Sancağı”, Tarih-i Osmani Encümeni Mecmuası, sayı 14, 1912, s. 860-861; ayrıca bkz. Fahrettin Kırzıoğlu, Osmanlıların Kafkas Ellerini Fethi (14511590), Ankara, Sevinç Matbaası, 1976, s. 272.

47 Âlî, Künhü'l-Ahbâr, vr. 506a; Derbend eyalet idaresinin detayları için bkz. Kütükoğlu, a.g.e., s. 68 . 
cakbeyliği olarak bahsedilmektedir. Ayrıca, ilk sancakbeyi yerel yöneticilerden seçilmiştir. Demirkapı'ya bir kadı, dümdar ve kale dizdarı da tayin edilmiştir. Belirli sayıda yeniçeri de kale muhafazasına bırakılmıştır (1579) ${ }^{48}$ Yerli bir idareci tarafindan yönetilse de Demirkapı-Şirvan eyaletinin idaresine tayin edilen Özdemiroğlu Osman Paşa'nın denetiminden çıkmamıştır. ${ }^{49}$ Paşa, Demirkapı'da istediği isimlere zeamet ve tımar dağıtabilmiştir. ${ }^{50}$ Osman Paşa'nın Safevilere ve Şirvan yerlilerine karşı mücadeleleri yüzünden Demirkapı'nın stratejik önemi de artmıştır. Güçlü Safevi orduları karşısında Şirvan'da tutunamayınca, Şubat 1579'da Demirkapı'ya göçen Osman Paşa burayı zamanla bir karargah haline getirmiştir. ${ }^{51}$ Destek için yanına gelen Kırım Hanı Mehmed Giray'ı Demirkapı'da ağırlamış ve Şirvan içlerine yapılan seferlerin kararlarını burada alınmıştır (15791580). ${ }^{52}$ Kırım Hanı'nın yanından ayrılmasını takip eden süreçte de Osman Paşa yine zor durumda kalınca yeniden Demirkapı'ya sığınmıştır. Ve en son bahsi geçtiği üzere 1583 'te Safevilere karşı zaferden önce ordusunu burada hazırlamıştır.

Cafer Paşa'nın Şirvan yerine Demirkapı muhafazasına tayin edilmesi, şehrin savaşlar boyunca öne çıkması ve Şirvan'ın diğer önemli şehirleri olan Şemahı ve Ereş'in ilk başlarda ayrı beylerbeyliği haline getirilmesiyle alakalı olabilir. Bir süre sonra kendisinden Şirvan muhafızı olarak bahsedilmesi de, Cafer Paşa'nın yetkisinin Demirkapı'yı da içine alacak şekilde genişletildiğini göstermektedir. Keza, 1583 yılı boyunca Osman Paşa'nın Şirvan muhafızı sıfatıyla buranın beylerbeylik ve sancakbeylikleri ile beraber idarî ve askerî düzen için yoğun bir me-

48 Songül Şenlik, "232 Numaralı Ruus Defteri (Metin-Değerlendirme)", (Yayınlanmamış Yüksek Lisans Tezi), İstanbul Üniversitesi, İstanbul, 2014, s. 219, 249, 255, 273, 331.

49 Mustafa Âlî Ereş'e gelen yerel beylerin Osman Paşa'yı ziyaret ettiklerini ve itaatlerini bildirdiklerini belirtir bkz. Âlî, Nusret-nâme, s. 159.

50 BOA, A.RSK. d. 1464, s. 5; Bunun dışında Özdemiroğlu Osman Paşa beş yıllık Şirvan muhafazası esnasında kendi ademlerine yetmiş dört zeamet ve altmış dokuz tımar dağıtmıştır. Bunları ihtiva eden defterde mevcut kendine ait mektupta ademlerinin y1llardır Safevilerle canla başla mücadele ettiğini ve bu sebepten onlara kendisi tarafından verilen tevcihatın kabul edilmesini Sultan III. Murad'dan istemiştir bkz. BOA, TT. d. 606, s. 1-15.

51 Osman Paşa'nın ricati esnasında Demirkapı'nın durumu hakkında kaynaklarda muhtelif bilgiler vardır. Âsafî’ye göre Osman Paşa önden adam gönderip şehrin vaziyetini rapor etmesini istemiştir. Safevilerden kaçan Tatarlıların kaleyi yağma ettiğini ve bu yüzden müdafilerin kaçtığını öğrenmiştir. Dağıstanlıların elinde kalan şehre mecburen giden Osman Paşa ve askerleri zahire kıtlığı yüzünden burada zor zamanlar geçirmiştir bkz. Âsafî, a.g.e., vr. 78b-81b; Benzer bilgiler için ayrıca bkz. Ebubekir bin Abdullah, a.g.e., vr. 41b-42a; Harîmî ve Mustafa Âlî ise Demirkapı'nın muhkem olduğunu ve zamanında top, tüfek ve sair levazımın tedarik edildiğini belirtir bkz. Harîmî, Zafernâme-i Sultan Murad Han, vr. 37b-38a; Âlî, Nusret-nâme, s. 228.

52 Kütükoğlu, a.g.e., s. 102-106. 
sai harcadığı göze çarpmaktadır. Ayrıca yerel halk ve ayanın yönetimi, tımar ve zeamet dağıtımları, muhtelif memurların tayinleri gibi hususlarda, hükümet başta Osman Paşa olmak üzere diğer beylere pek çok hüküm ve nişan göndererek süreci takip etmiştir. Dolayısıyla Osman Paşa vazifesini Cafer Paşa'ya tevdi ederken halihazırda bölgenin yönetim birimlerinin de temelleri atılmıştır. ${ }^{53}$ Vezaretle Demirkapı ve Şirvan muhafazası vazifesini üstlenen Cafer Paşa'dan en başta bölgedeki bu idarî ve askerî yapılanmayı koruması ve sürdürmesi beklenmiştir. Bu faaliyetler ve önlemleri ile Şirvan'1 en nihayetinde Osmanlı eyaleti seviyesine çıkarması da hedeflenmiş olmalıdır. İlk esnada Osman Paşa'nın kararına müteakiben hükümetin gönderdiği hükümlerde Cafer Paşa'nın vezaretle Demirkapı muhafazasına atanması tasdik edilmiştir. Emektar ve ihtiyar Cafer Paşa'nın Demirkapı muharebesinde ve diğer faaliyetlerdeki gayret ve başarıları Osman Paşa tarafından başkente iletilmiştir. Başarıları karşıllğında mezkûr makam kendisine bağışlanmıştır (Temmuz 1584). ${ }^{54}$ Cafer Paşa'dan sonra muhafaza için bölgede bulunan askerlere de hükümler gönderilmiş ve Paşa'nın maiyetinden ayrılmamaları ve bütün işlerinde paşaya destek olmaları emredilmiştir. ${ }^{55}$

Vazifeye kabulünün hemen ardından, Cafer Paşa'ya bölgedeki askerî hususlarda gözetmesi beklenen usuller açıklanmıştır. Hizmetleri karşılığında istediği isimlere mansıp, dirlik yahut terakki dağıtmasına müsaade edilmiştir. Bunu yaparken ruus tutup tayinleri kaydetmesi ve hükümlere tuğra-yı hümâyûn çekmesi talimatı verilmiştir. ${ }^{56} \mathrm{Kul}$ taifesinin reaya ve ahaliye zarar vermesini önlemesi ve kuldan mevcut olanların ulufeleri ve bölüklerini deftere yazıp göndermesi de ayrıca belirtilmiştir. ${ }^{57}$ Demirkapı muhafazasında olan kul ve gönüllülerden mahlul kalan gedikleri ağaların marifeti olmadıkça başkalarına vermemesi hususunda

53 Osman Paşa'nın Cafer Paşa yardımına gelmeden önce Şirvan ve Demirkapı genelinde yaptığı düzenlemelere hükümetin gözetimi altında devam ettiği anlaşılmaktadır. Bu maksatla Osman Paşa ve Şirvan'da bulunan beylere çok fazla hüküm ve sair mevzularda nişân-1 hümâyûn gönderilerek bölgedeki bayındırlık ve yönetim aygıtlarının belirli bir düzen dahilinde oluşturulması istenmiştir. 1583 yılında yazılan hükümleri ihtiva eden defter için bkz. BOA, A. NŞT. d. 1108, s. 419-.

54 Aynı tarihlerde Osman Paşa'nın İstanbul'a döndüğü dikkate alınırsa Cafer Paşa'yı Demirkapı muhafazası için atamasının tasdik edildiği anlaşılır bkz. BOA, MD, 53, hk. 270; Ayrıca Cafer Paşa'nın bu hükümde anlaşıldığına göre hala Kefe beylerbeyi mansıbını koruduğu anlaşılır. Fakat bu durum bir süre sonra değişir ve Kefe beylerbeyliği Eylül 1584'de düşürülür bkz. BOA, KK. d. 244, s. 17.

55 BOA, $M D, 53$, hk. 272.

56 BOA, $M D, 53$, hk. 273.

57 BOA, $M D$, 52, hk. 1000, 19 Rebiyülahir 992. 
da uyarılmıştır. ${ }^{58}$ Cafer Paşa bir taraftan hükümetin askerî hususlardaki uyarılarını alırken diğer taraftan muhtelif isimlere hizmetleri karşılı̆̆ında verdiği timar ve diğer tevcihleri kayda geçirmiştir. ${ }^{59}$

Bu talimatları yanı sıra, Cafer Paşa'yı merkezî hükümet aynı zamanda bölgenin çeşitli askerî ihtiyaçlarını karşılamaya çalışmıştır. Sadrazam Koca Sinan Paşa'nın bile Cafer Paşa' dan ulufe aldığı iddiasıyla Şirvan'dan başkente gelenleri tahkik ettirerek katkı sağladığ ${ }^{60}$ süreçte Demirkap1 ve Şirvan'a birçok askerî kıta sevk edilmiştir. Ağustos 1584'de Demirkapı için iki yüz elli nefer gönüllü gönderilmiştir. Paşa'dan gönüllüleri bizzat yoklaması ve verilecek ulufelerin kayıtlarını tutması istenmiştir. ${ }^{61}$ Mart 1585 'de yeni kul bölüklerinin yola çıktığı haberi verilirken Cafer Paşa'ya Şemahı, Ereş ve sair mahallerin kul askerlerini kollaması, düşmana müdara etmesi ve Şemahı'yı koruması da emredilmiştir. ${ }^{62}$ Aynı yılın mayıs ayında 'Demirkapı veziri' olarak anılan paşaya bu defa Şirvan muhafazası için topçu tarikiyle kul oğulları ve topçuluğa giden bölük halkından kişilerin defterleri hazırlanıp irsal edilmiştir. ${ }^{63}$ Ayrıca Kefe ve Kırım'dan da bölgeye hazine ve askerî teçhizat takviyeleri yapı1mıştır. ${ }^{64}$

Demirkapı ve Şirvan'da Osmanlı hakimiyetinin yerleşmesi için askerî istikrar yanı sıra Cafer Paşa'nın bazı idari ve ekonomik düzenlemeler yapması da gerekmiştir. Eylül 1584'de Şirvan eyaletinin tahriri için mal defterdarı Süleyman ve Abbas'ın görevlendirildiği konusunda bilgilendirilmiştir. Bu memurların adet ü kanun ve bölgenin durumuna uygun biçimde yapacakları tahrir işlemlerine muavenet etmesi için, her beldeden güvenilir bir adamını vazifelendirmesi talimatı da Paşa'ya verilmiştir. Tahrir için hazırlanan defterlerin bir kopyası İstanbul'a gönderilecek ve biri de Şirvan'da muhafaza edilecekti. ${ }^{65}$ Şubat 1585 'de ise kapsamlı

58 BOA, $M D$, 53, hk. 366, 27 Recep 992.

59 Cafer Paşa'nın 1584-1585 yılları arasında tımar, zeamet, müteferrika tevcihlerine dair bazı kayıtlar için bkz. BOA, KK, d. 242, s. 36, 118, 134, 145; KK. d. 244, s. 43, 169; KK. d. 247, s. 34, 35; BOA, $M D, 60$, hk. 427.

60 Koca Sinan Paşa'nın Telhisleri, s. 33-34.

61 BOA, $M D, 53$, hk. 992.

62 BOA, $M D, 53$, hk. 776.

63 Kul oğullarına topçu tarikiyle dokuz akçe ve topçuluğa gidenlere ikişer akçe terakki verildiği belirtilmiş, Cafer Paşa'dan mezkurları gereği gibi Şirvan muhafazasında istihdam etmesi tembihlenmiştir bkz. BOA, $M D, 53$, hk. 873.

64 Haziran 1586'da Kefe beylerbeyine ve Kırım Hanı'na gönderilen hükümlerde Cafer Paşa'nın hazine ve silah istediği bildirilmiş ve nasıl gönderileceği hususunda fikirleri istenmiştir bkz. BOA, $M D$, 60, hk. 636, 637; BOA, $M D, 61$, hk. 49.

65 Aynı şekilde tahrirle görevli mal defterdarı Süleyman'a da vazifesiyle alakalı hüküm gönderilmiştir bkz. BOA, $M D, 53$, hk. 459, 460. 
bir idarî taksimat ve tanzimin hususları Cafer Paşa ile paylaşılmıştır. Buna göre yeni bir tahrire kadar Ereş beylerbeyine hass tayin edecek ve Şirvan sınırlarında olan yedi sancağı Ereş beylerbeyliğine tabi kılacaktır. Sancakbeylerinin salyanelerinin münasip görülen mahalden tayin etmesi için yetkiye sahip olacaktır. Bunun yanında, hükümet Şirvan'ın en önemli üretim ve ticarî metası olan ipek ile alakalı kararı da açıklamıştır. Cafer Paşa, Ereş'den Demirkapı'ya kadar olan bölgedeki ipek hasılatını tümüyle miriye zapt edecek ve hariçten kimseyi ipek tahsilatına katiyen karışmasına müsaade etmeyecektir. ${ }^{66}$ İran coğrafyasında mühim üretim merkezlerinden biri olan ve daha çok Rusya üzerinden ticareti yapılan Şirvan ipeği böylece tümüyle devlet kontrolü altında olacaktır. ${ }^{67}$

Bütün bu idari ve iktisadi düzenlemelerin bölgedeki ayanlar ve halk nezdinde kabul görmesine de dikkat edilmiştir. Hükümet yerel halka hitaben gönderdiği yazıda artık Osmanlı memleketi olan Şirvan'ın ayanı ve ahalisi sayıldıklarını hatırlatmış ve yaşam şartlarını en iyi hale getirme sözü vermiştir. Bu minvalde, Demirkapı veziri Cafer Paşa, diğer idareci ve askerlere halka belirli kaidelerin dışında muameleyi yasaklayan emirler gönderildiği belirtilmiştir. Onlardan Osmanlı hakimiyetinin kalıcı olduğunu bilerek işleriyle meşgul olmaları istenmiştir. Osmanlı askeri tarafından herhangi bir zarara uğratılmaları veya baskıya maruz kalmaları halinde sultana başvurabilecekleri söylenmiştir. ${ }^{68} \mathrm{Bu}$ hususlarda, Cafer Paşa da üzerine düşeni yapmaya çalışmıştır. Mesela bölge ticareti güvenliği için şartlarda sürdürülmesi için Demirkapı'ya beş günlük mesafede bulunan Terek'deki eski hisarın yenilenmesine mesai harcamıştır, ki bu sayede Dağıstan, Buhara, Kazvin gibi yerlerden gelen bezirgan ve tacirler, Kızılbaş ve Rus tehlikesine maruz kalmadan mallarını Demirkapı'ya getirebilecektir. Kefe ile Demirkapı arasındaki irtibat, bu kaleyle beraber daha güvenli hale gelecektir. Deniz kenarında bulunması hasebiyle deniz mahsullerinden de faydalanılabilecektir. ${ }^{69}$

66 Aynı içerikte bir hüküm Ereş beylerbeyine gönderilmiş ve Cafer Paşa'nın tasarruflarına uymas1 istenmiştir bkz. BOA, MD, 53, hk. 739, 740.

67 Şirvan'da ipekçilik ve ipek ticareti için bkz. Rudolph Matthee, The Politics of Trade in Safavid Iran: Silk for Silver, 1600-1730, Cambridge, Cambridge University Press, 2000, s. 28-31, 39-41, 54; Savaşa bizzat katılan ve Ereş'e Osmanlı ordusuyla giren Ebubekir bin Abdullah "Kasaba-i Ereş kendüsi bir bâ̆g $\hat{u}$ bağca içindedir nihâyet-i meyve-gândır ve Şirvan ipeği şehr-i mezkûrda hâsıl olur ve bâzirgânlar ipek yüklerin anda bağlarlar” diyerek şehrin ipek üretimindeki önemine dikkat çekmiştir bkz. Ebubekir bin Abdullah, a.g.e., vr. 19a-19b.

68 BOA, $M D$, 53, hk. 717, 01 Safer 993; Aynı tarihlerde Şemahı'da bulunan gönüllü kullara gönderilen hükümde Şemahı, Şeki ve sair bölgelerin halkının artık memalik-i mahrûse reayası olduğu hatırlatılmış ve onlara hiçbir şekilde zarar vermemeleri için uyarılmıştır bkz. BOA, $M D, 53$, hk. 738, 14 Safer 993.

69 Cafer Paşa'nın kalenin yapımının faydalarını sıraladıktan sonra merkezden inşaata onay gel- 
Demirkapı'da geçirdiği üç yılın ardından, Cafer Paşa bölgenin idari ve ekonomik durumu hakkında hükümete bir rapor hazırlamıştır. Rapora göre Dağıstan ve Gürcistan'da Safevi tehdidinin bertaraf edilmesiyle yerlerini terk eden üç-dört bin hane tekrar Şirvan'a dönüp yerleşmiştir. 1585 senesinde seksen yedi yük akçe - ki Şirvan hesabına göre iki yüz yük akçedir- merkeze göndermiştir, Gence ve etrafı fethedildiği takdirde bu miktar artacaktır. Kul taifesi ve diğer masraflar için seksen yük akçe harcanmıştır. Neticede otuz yük Şirvanî akçe -ki Osmanlı akçesi ile on üç yük eder- ve dört bin batman ipek hazineye kalmış ve bunlar merkeze gönderilmiştir. Şirvan'daki tüm mahsuller kayıt altına alınmıştır. Sadece çeltik hasılatına dair kayıtların eksik kaldığından bahseden Cafer Paşa kısa sürede bu işi de halledeceğine garanti vermiştir. Paşa'nın bu çabalarını takdir eden Sultan III. Murad ise, hizmetlerinde ötürü onu tebrik etmiştir ve her daim onun için dua ettiğini söylemiştir. ${ }^{70}$

Cafer Paşa'nın idareciliğinin Sultan ve hükümet nezdinde büyük takdir topladığı anlaşılmaktadır. Paşa, Ağustos 1586'da gönderdiği yazısında Şirvan eyaletinin büsbütün emniyet altına alındığını ve askerlerle hiç sorun yaşamadığını merkeze bildirmiştir. Aradaki süre zarfında, beylerbeyleri yerel yöneticilerden atanan Dağıstan, Tebesaran, Kaytak ve Kumuk vilayetlerinde Osmanlı hakimiyeti yerleşmiştir. Paşa'ya göre, yalnızca kul mevaciblerini ödenmesinde sıkıntı yaşanmaktadır. Kendisine gelen cevapta, ödemeler için gerekli hazinenin yollandığı haber edilmiştir. $\mathrm{O}$ ana kadar yaptıkları ve sahip olduğu yöneticilik meziyetleri tekrar övülmüştür. Başta askerler olmak üzere her mevzuda kararları vermeye muktedir olduğu söylenmiş ve münasip gördüğü şekilde tedbir alması teşvik edilmiştir. ${ }^{71}$

\section{Cafer Paşa'nın Şirvan'da Askerî Faaliyetleri ve Ömrünün Son Seneleri}

Demirkapı muhafazasında bulunduğu süre boyunca, Emektar Cafer Paşa devam eden seferler nedeniyle bölgedeki askerî gelişmelerden etkilenmiştir. Henüz görevdeki ilk senesinde, Osmanlı ordusunun kışlaklara dağıldığ Gence'deki Yirmi Dört Paye ulusunun beyi Mustafa, oğulları, akrabaları ve as-

miş ve gerekli malzemeler konusunda yardım edileceği belirtilmiştir bkz. BOA, $M D, 60$, hk. 271, 17 Zilhicce 993.

70 Hükümde ayrıca bölgedeki asker halkı idare etmesi ve iyi yönetimi sürdürmesi teşvik edilmiştir bkz. BOA, $M D, 62$, hk. 332.

71 BOA, $M D, 61$, hk. 210; Aynı tarihte kullar ağasına ve kul taifesine gönderilen hükümde de maaşlarının tedariki için hazine gönderildiği haberi verilmiştir bkz. hk. 215; Ayrıca bölgedeki sancakbeylerine de Cafer Paşa'ya hizmetlerinden dolayı inayetlere mazhar olacakları söylenmiş ve hizmetlerine devam etmeleri istenmiştir bkz. hk. 212. 
kerleri ile Cafer Paşa'nın yanına gelip itaatlerini sunmuştur. Hizmette bulunmaları için Demirkapı, Şemahı ve Kabale kalelerine dağıtılan aynı beyler bir süre sonra Safevi şehirlerine saldırmaya başlamıştır. Özellikle Kabale Kalesi muhafazasında olanlar Gence ve etrafına yağma akınları düzenlemiş ve önemli Safevi komutanlarını öldürmüştür. Bunun üzerine, hükümet Cafer Paşa'dan Gence ve Berda'nın beylerbeyilik tarikiyle Mustafa'ya tevcih etmesini istemiştir. ${ }^{72}$ Birkaç sene sonra Serdar Ferhad Paşa'nın fethedeceği Gence'ye Cafer Paşa zamanında Osmanlı tâbi beyler aracılığıyla ilk ciddi saldırılar gerçekleştirilmiştir.

Cafer Paşa, Demirkapı'da yan yana savaştı̆̆ı Özdemiroğlu Osman Paşa'nın Tebriz seferine çağırılmamıştır (1585). Safevilerin sefer esnasında Demirkapı ve Şirvan'a saldırı ihtimalleri bu karara tesir etmiş olmalıdır. Keza Tebriz fethinden hemen sonra paşaya yazılan hükümde sefer nedeniyle düşmanın Şirvan bölgesine olası misilleme harekâtlarına dair bir endişe göze çarpar. Hükmün başında Tebriz'in fethinden sonra Osman Paşa'nın ölümü üzerine Safevilerin karşı saldırıya geçmesinden bahsedilmiştir. Ricat etmek zorunda kalan Osmanlı ordusu düşmanla savaşmış ve muzaffer olmuştur. Galibiyete rağmen serdarını kaybeden Osmanlı askerleri Erzurum ve Van etrafına firar etmiştir. Bu gelişmeler üzerinden Safevilerin Şirvan ve Demirkapı'ya saldırma olasılığı düşünülerek Cafer Paşa'dan da durumu hakkında bilgi vermesi istenmiştir. Kendisine düşmanın faaliyetleri, reayanın hali gibi pek çok mesele hakkında sorular yöneltilmiştir. Her ihtimale karşı gerekli önlemleri alması ve kaleleri tahkim etmesi için uyarılarda bulunulmuştur. ${ }^{73}$

1586'nın son aylarında Cafer Paşa, Şemahı ve Kuzey İran'dan pek çok yerli beyin Osmanlı hakimiyetini tanıdığı bilgisini başkentle paylaşmıştır. Karşılığında hükümet bu beylere hil'atler göndermiş ve Paşa'ya da iyi hizmetlerinin devamı için temennide bulunmuştur. ${ }^{74}$ Cafer Paşa 1588 'e kadar asker maaşları dışında sakin ve nispeten sıkıntısız bir dönem geçirmiştir. Aradaki dönemde, kendisinin faaliyetleri hakkında detaylı bilgilere ne arşiv kayıtlarında ne de dönem kaynaklarında rastlanılmaması bu kanaate dayanak oluşturur. Fakat 1588'de gerek Ferhad Paşa'nın seferleri gerekse Şirvan'da yaşanan asker ayaklanmaları nedeniyle ömrünün son senesini dolu dolu yaşamıştır.

Özdemiroğlu Osman Paşa'nın Tebriz seferine katılmayan Cafer Paşa, Serdar Ferhad Paşa'nın seferlerine iştirak etmiştir. Ferhad Paşa 1583'de ilk serdarlığı es-

72 Hükümde Cafer Paşa'ya talep ettiği barut, hazine ve diğer levazımları gönderme sözü verilmiş ve bölgesini, askerini muhazafa etmesi istenmiştir bkz. BOA, $M D, 60$, hk. 318 .

73 BOA, $M D, 60$, hk. 285, 29 Zilhicce 993.

74 BOA, $M D, 61$, hk. 211, 213, 214. 
nasında Gürcistan ve Şirvan'ın güneyinde kalan önemli hisarları ve şehirleri hedef almıştır. Bu dönem Revan'1 zapt ederken Tiflis'e yakın Tomanis ve Lori kalelerini inşa etmiş ve Gürcistan üzerinde hakimiyeti pekiştirmiştir. ${ }^{75} 1586$ ' da ikinci defa serdarlığa atanmış; 1587'de başlayan seferde Karabağ ve Gori üzerine gitmiş ve şehir hakiminin itaatiyle mücadelesiz bir fetih gerçekleştirmiştir. Ana orduya çağırılmamasına rağmen, Cafer Paşa da sefer esnasında müstakil bir saldırı için vazifelendirilmiştir. Mart 1587 yazılan bir mektupta o ana kadar Demirkap1 ve Şirvan'da yaptıkları uzunca övüldükten sonra Serdar Ferhad Paşa'nın Karabağ'ı fethetmeyi amaçladığına dair kendisine malumat verilmiştir ve emrindeki beylerle düşman topraklarına akın yapması emredilmiştir. Bilhassa Bakü'den beş konak uzaklıkta bulunan Erdebil hedef olarak gösterilmiştir. ${ }^{76}$ Şirvan beylerine gönderilen ayrı bir emile kendilerine Paşa'nın yanında toplanmaları ve saldırılar boyunca onun direktiflerini uygulamaları tembih edilmiştir. ${ }^{77}$ Serdarın emrinde ana ordu sahadayken, Cafer Paşa'dan düzenlemesi istenen bu özel harekât ile büyük ihtimalle Safevilerin organize bir cephe hattı oluşturması engellenmiştir. Paşa'nın Karabağ ve Gence'ye yakın düşman şehirlerini meşgul etmesi sayesinde olası bir destek ordusunun önü kesilmek istenmiştir. Ancak, Ferhad Paşa'nın ilk seferi umulduğu gibi başarılı olmamış ve Gence ile Karabağ fethi bir sonraki seneye sarkmıştır. Cafer Paşa da harekâtı tamamlayınca, kış dönemini Demirkapı ve Şirvan'daki kapı halkının çıkardığı ayaklanmaların gölgesinde geçirmiştir.

Aralıklarla Cafer Paşa'nın raporlarına da yansıyan Şirvan ve Demirkapı'da kul taifesinin maaşlarının zamanında ödenememesi zamanla ciddi bir hal almıştır. Öyle ki hükümetin kayıtsız kalmasına daha fazla dayanamayan bölgedeki kapıkulu askerleri şikayetlerini başkente taşımıştır. Selânikî’nin şahitliğine göre Nisan 1587'de Cafer Paşa kendi kethüdasının liderliğinde yeniçeri bölük-başlarından ve dirlikli askerlerden oluşan bir heyeti sorunu çözüme kavuşturmak için İstanbul'a göndermiştir. Gürcistan üzerinden yola koyulan heyet, Tatarlar gibi kalpaklar giyinmiş halde ve zor şartlara göğüs gererek başkente varmıştır. Askerler dört yıldır ulufelerini alamadıklarını, "mübtelâ-1 kıllet ve iflâs" üzere yaşadıklarını zira bölgedeki mahsulün eyaletin masraflarını ancak karşılayabildiğini söylemiştir. Neticede halleri perişandır. Askerlerin şikayetlerine karşıllık ulufeleri ve libaslarının mümkün olan yerlerden tedarik edilmesi için fermanlar yazılmıştır. $^{78}$

75 Kütükoğlu, a.g.e., s. 133-144.

76 BOA, $M D, 62$, hk. 76.

77 BOA, $M D, 62$, hk. 70, 73, 74, 75.

78 Selânikî, a.g.e., c. I, s. 183. 
1588'in hemen başında Cafer Paşa'ya gönderilen oldukça uzun bir hükümden Şirvan'daki yeniçerilerin ve diğer kapıkulu askerlerinin maaşlarının hâlâ ödenememesinin daha ciddi olaylara yol açtığı anlaşılmaktadır. İlgili hükmün ilk kısmında Şirvan muhafazasına destek için gelen Kırım Hanı oğullarının hallerinden ve Safevilerin artık saldırı yapamayacak durumda olduğundan kısaca bahsedilmiştir. Hanın üç oğlundan ikisi Ruslara iltica etmiş ve biri de Çerkezler yanında sefalet içine düşmüştür. Düşman tehdidinden eser kalmamasına rağmen kapıkullarının dört yıldır ulufe alamamaları ise bölgedeki düzeni sarsmıştı ve asker arasında huzursuzluğu arttırmıştır. Daha kötüsü Ereş Beylerbeyi Mustafa Paşa ve kethüdası Buçuk oğlu Ahmed Bey bu vaziyetten faydalanıp bazı olayları tetiklemiştir. İlgili belgeye göre Mustafa Paşa, para gönderilemeyeceği şayiasını askerler arasına yaymıştı; Cafer Paşa'nın da azledilip İstanbul'a kaçacağını ve yerini kendisinin alacağını ileri sürmüştü. Zaten sıkıntıda olan kul taifesi bunun üzerine dört yıldır biriken ulufelerini almak maksadıyla Cafer Paşa'ya saldırmıştı. Paşa'nın hazinenin yolda olduğunu söylemesi işe yaramamış ve asiler teklif edilen Şirvanî akçeyi de kabul etmemiştir. Cafer Paşa mevcut mahsulleri askerlere vermeye çalışmış, kifayet etmeyince asiler ipek mahsulünü gözüne kestirmiştir. İpeklere el koyan askerler, gaspettikleri ipeği değerinin altında satmıştır. Bununla da yetinmeyen askerlerin sonraki hedefi ulufe hesabını değiştirmek olmuştur. Baskı altına aldıkları Cafer Paşa'ya merkeze bir yazı yazmasını ve altının artık yüz yirmi ve kuruşun seksen akçe hesabı ile işleneceğini başkentte bildirmesini istediler. Şimdiye kadar kapıkulu askerlerine otuz akçe verildiğini söyleyen Paşa, yapılan değişiklikle böyle bir miktarın ödenemeyeceğini söylemiştir. Halihazırda floriyi altmış, kuruşu kırk ve Bağdadî’yi yirmi beş akçe üzerine hesaplandığı halde bile hazinenin durumu kötüyken zikrolunan hesabın yapılamayacağını belirtmiştir. Cafer Paşa, olası Safevi saldırılarına dikkat çektikten sonra asilerle orta yolu bulmaya ve onları İstanbul rayici üzerinden ulufelerini almak için ikna etmeye çalışmıştır. Demirkapı ve Şirvan'da takdire şayan hizmetler etmiş askerlerin biriken sıkıntılarına hükümetin de Cafer Paşa'nın önerilerinden öte bir çözüm bulamadığı ortadadır. Olayı uzun uzun özetleyen hükmün sonunda, Cafer Paşa'ya göz dağı vermek amacıyla isyan çıkaran askerlerden bazılarına ceza vermesi emredilmiştir. Bunca zamandan beri başarıyla idare ettiği bölgede hizmetlerinin devamı için ayrıca teşvik edilmiştir. ${ }^{79}$

Kul taifesinin maaşları nedeniyle çıkardığı isyan, bölgedeki diğer yerel beyler, beylerbeyleri ve sancakbeylerinin de dikkatine sunulmuştur. Suretleri gönderilen hükümlerde, Cafer Paşa'nın maiyetindeki yeniçerilerin körükledikleri ayaklan- 
madan ve altmış yük ipeği değerinin altında satmalarından bahsedildikten sonra belirlenen hesaptan ulufelerini almayıp miriye zarar verdiklerine de değinilmiştir. Aynı beylere, ihtiyaç halinde Cafer Paşa'nın yanında yer almak için hazırlıklı olmaları ve gerektiği zaman harekete geçmeleri emredilmiştir. ${ }^{80}$ Demirkapı ve Şirvan'da bir müddet sıkıntıya neden olan ve yeni fethedilen bir bölgede askerî idarenin yetersizliklerine işaret eden bu hadisenin nasıl sonuçlandığı dair kesin bir malumat yoktur. Bu nedenle olayın askerlerin zorla ele geçirdikleri mal ve parayla tatmin olmasıyla veya ulufelerinin ödeneceğine dair taahhütleri kabul etmeleriyle sonlandığ 1 farz edilebilir. Nitekim, kısa bir süre sonra Ferhad Paşa'nın Gence seferine Cafer Paşa eyalet askerleriyle katılabilecektir.

Gence seferi, Temmuz 1588'de Serdar Ferhad Paşa'nın Erzurum'dan hareket etmesiyle başlamıştır. Anadolu, Rumeli ve yeni Acem eyaletlerinden beylerbeyin askerleriyle peyderpey orduya katılmasıyla yürüyüş devam etmiş ve Eylül başlarında Gence'ye varılmıştır. Kaledeki Safevi yönetici mukavemet göstermeksizin geri çekildiği için bir mücadele yaşanmamış; Ferhad Paşa zahmetsiz şekilde şehri fethetmiştir. Serdar ele geçirilen şehrin muhafazası için vakit kaybetmeden gerekli adımları atmak için kolları sıvamıştır. Tamirat sürerken, Emektar Cafer Paşa da emrindeki birliklerle şehre ulaşmış; önceden yöneticileriyle iletişime geçerek Osmanlı hakimiyetini kabul ettirmek istediği Gence ve civarının fethine bizzat iştirak edebilmiştir. ${ }^{81}$ Fetihten bir hafta sonra şehre giren Cafer Paşa büyük bir tazimle karşılanmıştır. Harîmî’nin kaleme aldığı sefer anlatısına göre, "vali-i vilâyet-i Şirvân Cafer Paşa-yı pür-iktidâr" orduya katılınca Serdar Ferhad Paşa ile görüşmek istemiştir. Tüm beylerbeylerinin törenle karşıladığı paşa daha sonra serdarın otağına davet edilmiştir. Ferhad Paşa Cafer Paşa'yı iltifat ve tazimle karşılamış, ayrıca Paşa'nın şehre varışı askerin neşesini de artırmıştır. ${ }^{82}$

Gence'nin tadilat işleri henüz tamamlanmışken şehri daha önce terk eden Safevi birliklerinin yeniden toplandığı ve karşı saldırıya geçmek için hazırlandığ 1 öğrenilmişti. Ferhad Paşa da derhal karşı saldırıya geçmeye karar vermiştir. Yaşlı olması nedeniyle Cafer Paşa bir miktar asker ile Gence muhafazasına bırakılmıştı. Osmanlı ordusu şehirden ayrıldıktan birkaç gün sonra Safevi ordusuyla karşılaşmış ve zorlanmadan düşmanı bozup dağıtmıştı. Gence'deki hakimiyeti iyice kesinleştiren bu zaferden sonra ordu şehre dönmüştür. Büyük şenliklerle

80 Hükmün on beş kadar sureti bölgedeki itaat halinde olan yerel beyler, beylerbeyleri, sancakbeyleri ve sair askerî rütbelilere gönderilmiştir bkz. BOA, $M D, 62$, hk. 451.

81 Cafer Paşa'nın girişimi ve sonrasında Gence'nin akıbeti için bkz. Kırzıoğlu, a.g.e., s. 365-366.

82 Rahimi-zâde İbrahim Harimî, Kitâb-ı Gencîne-i Feth-i Gence, haz. G. Karaağaç, A. Eskikurt, İstanbul, Çamlıca Yayın Basım, 2010, s. 49. 
kutlanan galibiyete bir ölüm gölge düşürmüştür. "Şikestelikle gelüp gitdükçe mizâc1 münharif ve marazı müşted" olan Cafer Paşa 2 Ekim 1588'de vefat etmiştir. ${ }^{83}$ Emektar Cafer Paşa, Gence kalesinin içinde yapılan cami kabristanında defnedilmiştir. ${ }^{84}$

\section{Saraydan Tebriz'e Hadım Cafer Paşa}

Osmanlı sancak ve eyaletlerine sancakbeyleri ve beylerbeyleri atamalarında 1570-1580 tarihinden itibaren yeni temayüller belirginleşir. Bu dönemde tayin edilen sancakbeylerinin ekserini saray kökenli ve daha önce idarî tecrübesi olmayan isimler oluşturur. Beylerbeyi makamlarını ise çok yüksek oranda sancakbeyliğinden terfi eden isimler doldurmuştur. Fakat özellikle 1580'den sonra merkezden eyaletlere doğrudan beylerbeyleri tayinlerinde de bir artış gözlemlenmiştir. ${ }^{85}$ Hadım Cafer Paşa'nın kariyer çizgisi kendi devrinde tayin ve terfilerde yaşanan değişime uygun seyredecektir. Saraydan eyalete tayinle başlayan idareci kariyerini Acem seferleri vesilesiyle itibar sahibi bir devlet adamı olarak sonlandıracaktır.

Gençliği ve saray hayatı için kesin bilgilere ulaşılamayan Cafer Paşa'nın kişisel hususiyetlerine dair İbrahim Peçevî'nin bazı gözlemleri mevcuttur. Peçevî, Eğri Seferi (1596) esnasında karşılaştığı Cafer Paşa'nın lisanından Macar asıllı olduğunu anlamıştır. Cesâmetli ve ak benizli bir adam olarak betimlediği Cafer'in gözü karalığı ile tanındığını ve okuma yazma bilmediğini söylemiştir. ${ }^{86}$ Macar kökenli Cafer'in hadım edilerek Osmanlı hizmetine girdiği ve muhtemelen haremde vazifeli olduğu anlaşılmaktadır. Enderundan yetişen devlet adamlarından farklı olarak eğitim almaması saray ve harem çevresiyle kurduğu ilişkilerinin ikbalini belirlediğini düşündürür. Akla gelen en makul açıklama önemli zevatla yakın ilişkileri çerçevesinde yapılabilecekken esasında diğer devletlüler ve haremlüler ile münasebeti hakkında da çok az ipucu vardır. Bir telhiste, Sadrazam Koca Sinan Paşa o esnada Tebriz'de olan Cafer Paşa'yı kaptan-1 derya adayı olarak Sultan III. Murad'a önermiş ve ondan övgü dolu sözlerle bahsetmiştir. ${ }^{87}$ Sinan Paşa'nın desteği Cafer Paşa ile yakın bir ilişkisi olduğuna alamet sayılabileceği gibi kapudanlık için diğer aday Cigalazâde Sinan Paşa'nın tercih edilmemesi

83 Harimî, Kitâb-ı Gencîne, s. 53; Selânikî Cafer Paşa'nın binden mütecaviz kapı askeriyle ordugaha geldiğini belirtir bkz. Selânikî, a.g.e., c. I, s. 207 Gence fethi ve muharebe için ayrıca bkz. Kütükoğlu, Osmanl1-İran, s. 191-194; Kırzıŏlu, a.g.e., s. 368-373.

84 Selânikî Cafer Paşa'nın Gence'de defnedildiğine dair bilginin kendisine söylendiğini belirtir bkz. Selânikî, a.g.e., c. I, s. 208.

85 Kunt, a.g.e., s. 59-67.

86 İbrahim Peçevî, Târîh-i Peçevî, c. II, İstanbul, Matbaa-1 Âmire, 1866, s. 120-121.

87 Koca Sinan Paşa'nın Telhisleri, s. 2-3. 
adına gösterdiği çabadan da ileri gelebilir. Lakin daha sonra görüleceği üzere kayda değer bir askerî tecrübesi olmamasına rağmen, Özdemiroğlu Osman Paşa tarafindan Tebriz muhafazasına bırakılması Cafer Paşa'nın önemli devlet adamları nezdinde muteber ve bazılarıyla da bağlantılı olduğunu düşündürür. Özellikle Cigalazâde Sinan Paşa ile münasebetine dair bazı ipuçları mevcuttur. Tebriz'de iken Cafer Paşa haremden önemli simalara yakın olduğu bilinen Cigalazâde Sinan Paşa ile birlikte Ferhad Paşa'nın ikinci defa Safevi serdarı ve sadrazam olmaması için çaba göstermiştir. ${ }^{88}$ Siyasi pozisyonlarının ortaklığı nedeniyle Cafer Paşa'nın Tebriz muhafazasına bırakılmasında da Sinan Paşa'nın etkili olduğu söylenebilir. Bunlar dışında Cafer Paşa'nın devlet adamlarıyla münasebetlerinin daha farklı detaylarına vakıf olunamamaktadır.

1576 senesinde Trablusgarp yeniden fethedilen Tunus'tan ayrilarak farklı bir eyalet statüsü kazanmıştır. Cafer Paşa, Aralık 1579'da Trablusgarp beylerbeyi atanarak kağıt üzerinde bu yeni eyaletin ilk beylerbeylerinden biri olmuştur. $\mathrm{Ne}$ var ki Paşa'nın İstanbul'da ayrılıp Trablusgarp'a varması oldukça gecikmiştir. ${ }^{89}$ $\mathrm{Bu}$ gecikmenin sonunda Trablusgarp'a varamadan görev yeri Cezayir-i Garp eyaleti olarak değiştirilmiştir. ${ }^{90} 1580$ yazında başladığı Cezayir beylerbeyliği va-

88 Levent Kaya Ocakaçan, “Geç 16. ve Erken 17. yy’da Osmanlı Devleti’ndeki Patronaj İlişkilerinin Gazanfer Ağa Örneği Üzerinden Venedik Belgelerine Göre İncelenmesi”, (Yayınlanmamış Doktora Tezi), Marmara Üniversitesi, İstanbul, 2016, s. 187-189.

89 Aralık 1579 tarihli hükümde Eğriboz beylne Cafer Paşa'nın yanına varınca Sakız ve Kavala beyleri ile beraber Trablusgarp'a geçirmesi istenmiştir bkz. BOA, MD, 39, hk. 138, 27 Şevval 987; Fakat Cafer Paşa'nın başkentten ayrılışı önce Şubat 1580'e sarkmıştır. Bu tarihte Kavala kapudanın Paşa'yı Trablusgarp'a götürmesi için gerekli hazırlıkları yapması emredilmiştir bkz. BOA, MD, 39, hk. 393 (5 Muharrem 988), 399 (7 Muharrem 988), 415 (10 Muharrem 988).

90 Muhtemelen kış boyunca Trablusgarp'a varamayan Cafer Paşa'nın görev yeri Temmuz 1580'de Cezayir-i Garp eyaleti olarak değiştirilmiştir. Bununla alakalı bilgi bu tarihte yeniçeri ağasına gönderilen hükümden öğrenilmektedir. Hükümde yeniçeri ağasından başkentten kadırgalar ile ayrılmaya hazırlanan Cafer Paşa'nın kadırgalarına iki yüz yeniçerinin gönderilmesi istenmiştir bkz. BOA, MD, 43, hk. 223, 27 Cemaziyülevvel 988; Kılıç makalesinde Mehmed Nuri ve Mehmed Naci tarafından hazırlanan Trablusgarp adlı esere atıf yaparak Cafer Paşa'nın 1582-1583 tarihlerinde Trablusgarp'da görev yaptığını belirtmiş ve kendisi Ekim 1584 tarihine kadar paşanın görevde kaldığını tahmin etmiştir. Fakat gösterdiği tarih aralığında Cafer Paşa Cezayir ve daha sonra Trabluşsam'a atanmıştır bkz. Orhan Kılıç, "16 ve 18. Yüzy1llarda Trablusgarp’ta Osmanlı Yönetimi ve Yöneticileri”, Prof. Dr. Salim Cöhce Armağanı: Tarihe Adanmış Çileli Bir Ömür, ed. Alpaslan Ceylan, Ankara, Berikan Yayınevi, 2017, s. 590; Bahsedilen telhiste de Koca Sinan Paşa kapudan olmasını istediği Cafer Paşa'dan bahsederken onun daha önce Cezayir-i Garp beylerbeyliği yaptığına değinmiştir. Deniz ve donanmaya vakıf olduğuna padişahı ikna etme amaçlı telhiste Trablusgarp görevi hakkında bir 
zifesini Şubat 1582 yılının başlarına kadar sürdürmüştür. Bu iki yıllık dönem hakkında evraklara yansıyan tek hadise, Cezayir çavuşlarının kethüdaları kendi içlerinden seçile gelmesine rağmen Paşa'nın hariçten kişileri tercih etmesi ve bu hususta hükümet tarafından uyarılmasıdır. ${ }^{91}$ Cafer Paşa görevden alındıktan sonra İstanbul'a çağırılmıştır. ${ }^{92}$

Azlinden sonra bir müddet açıkta kalan Hadım Cafer Paşa, Serdar Ferhad Paşa'nın sefere çıkmaya hazırlandığı sırada yeni vazifesi belli olmuştur. Önce serdarın yanında Acem seferine katılması emredilmişken, bu durum Bağdat cephesindeki gelişmelere binaen değişmiştir. Trabluşsam beylerbeyi olan Ali Paşa'nın Şam muhafazasına nakledilmesi gündeme gelmiş; fakat Bağdad cephesine asker gönderilmesi gerekince bu görev değişimi iptal edilmiştir. İki meseleyi birden halletmek için hükümet Cafer Paşa'yı Trabluşsam muhafazasına tayin etmiştir, vazifesi kapsamına Şam mıntıkası da dahil edilmiştir (Şubat 1583). ${ }^{93}$ Cafer Paşa yaklaşık bir sene boyunca Trablusşam'ın idare ve asayiş meseleleriyle meşgul olmuştur. Dürzilerin bölgede sebep olduğu sorunları önlemek üzere bu grubun ellerindeki ateşli silahlarını toplatmıştır. ${ }^{94}$ Hama sakinlerinden Abdülvahhab oğullarının sebep olduğu karışıklıkları önlemiş ve bölge ahvalini teftiş etmiştir. ${ }^{95}$

şey söylememesi Cafer Paşa'nın burada vazife almadığına ayrı bir kanıt mesabesindedir bkz. Koca Sinan Paşa'nın Telhisleri, s. 3.

91 BOA, $M D, 45$, hk. 994, 21 Cemaziyülahır 989.

92 BOA, $M D$, 46, hk. 727, 12 Muharrem 990; Ayrica yeni beylerbeylerine askerlerin muharebe ve muhafazada gösterdikleri başarıların Cafer Paşa tarafından hükümete bildirildiği ve buna göre muamele etmesi emredilmiştir bkz. BOA, MD, 46, hk. 745 (17 Muharrem 990); Cafer Paşa'nın hangi tarihte Cezayir beylerbeyliği yaptığı ile alakalı modern çalışmalarda farklı iki bilginin paylaşıldığı dikkat çeker. Kılıç, Aziz Samih'in Şimalî Afrikada Türkler adlı eserini referans vererek Aralık ayının son günleri veya Ocak 1583'de paşanın Cezayir'e atandığını yazmıştır. Kısa süre sonra Paşa'nın Trabluşsam'a atandığını belirtmiştir bkz. Orhan Kılıç, "Beylerbeyilerden Dayılara Cezayir-i Garp Vilayeti/Eyaleti'nin Yönetimi ve Yöneticileri (1618. Yüzyıllar)", Cappadocia Journal of History and Social Sciences, say1 9, 2017, s. 428; Taş ise ruus defterine başvurarak Cafer Paşa'nın Nisan 1580'de beylerbeyi atandığını tespit etmiştir. Fakat iki yıllık görev süresinin ardından Paşa'nın Trablusgarp'a atandığını yazmıştır. Küçük bu hatasını daha sonra Cezayir beylerbeylerini listeleyen tablosunda düzeltmiştir bkz. Abdullah Erdem Taş, "Cezâyir-i Garb Vilâyeti'nin Kuruluşu Meselesi ve İlk Cezâyir Beylerbeyileri”, İslam Medeniyeti Araştırmaları Dergisi, cilt 5, sayı 2, 2020, s. 269-270; Neticede Taş'ın paylaştığı bilgiler kayıtlara dayandığı için doğru iken Kılıç'ın verdiği tarihler hatalıdır.

93 BOA, $M D$, 44, hk. 302, 1 Safer 991; BOA, MD, 49, hk. 420, 13 Cemaziyülahır 991; Trabluşsam beylerbeyi Ali Paşa'ya Şam muhafazası meselesinin ortadan kalktığı vakit kaybetmeden Bağdad'a gitmesi emredilmiştir bkz. BOA, $M D, 44$, hk. 306, 11 Safer 991.

94 BOA, $M D, 44$, hk. 337, 26 Safer 991.

95 BOA, $M D$, 49, hk. 34 (15 Rebiyülevvel 991), 304 (16 Cemaziyülevvel 991); Abdülvahhab 
Yine Trablusşam' da halktan zorla akçe toplayan ve rencide eden bir eşkıyayı yakalamıştır. ${ }^{96}$ Bunların yanı sıra, Kıbrıs'da bulunan kadırgalar için kürekçi temin etmiş; Şam'da yaşanan kıtlık üzerine gemilerle kendisine gönderilen malları şehre ulaştırmıştır. ${ }^{97}$ Cafer Paşa'nın Trablusşam muhafazasında yerine getirdiği bütün bu hizmetleri hükümet de takdir etmiştir (Eylül 1583). ${ }^{98}$

1583 yılı Acem seferi sona erince Ali Paşa Trablusşam'a dönmüş ve Cafer Paşa'nın vazifesi sonlanmıştır. Başkentten gönderilen emirde ondan adamları ile beraber bir münasip ucuzluk yerde kışlaması istenmiştir. ${ }^{99} \mathrm{~K}$ ış boyunca Trablusşam'da ikamet eden Paşa, bu sırada bölgede bazı atamalarda rol almayı sürdürmüştür. ${ }^{100}$ Ocak 1584 'de ise daha önce kendisine verilen inayet sözü tutulmuş ve Ali Paşa'nın yerine Trabluşsam beylerbeyliğine getirilmiştir. ${ }^{101}$ Yaklaşık bir sene daha eyaletin idaresini üstlenen Cafer Paşa'nın faaliyetlerine dair bazı tevcihleri dışında yine fazla bilgiye erişilememektedir. ${ }^{102}$ Trablusşam'da bulunan Venedikli tacirlere yönelik Halep'teki bazı memurlarla birlikte ahidnâmeye muhalif faaliyetlerde bulunduğu öğrenilmektedir. Venedikli tacirlere ait çuka ve kumaştan elde edilen gelirden elli bin altınlık kısmına pek çok devlet görevlisi zorla el koymuştur. Bunlardan biri olan Hadım Cafer Paşa kendi hesabına beş bin altın almıştır. ${ }^{103}$ Teftiş edilmesi ve gereğinin yapılması tembihlenen hadise yüzünden Paşa'nın hükümet nezdinde itibarının zedelenmiş olması mümkündür. Hatta görevden alındıktan sonra bizzat kendisi hükümete yazdığ 1 raporlarda Trablusşam tahririnde de usulsüzlükler yaptığını itiraf etmiştir. ${ }^{104}$ Mayıs 1585 'de Trabluşsam

oğullarının meselesi Serdar Ferhad Paşa'ya da haber edilmiş ve ondan da gerekli önlemleri alması istenmiştir bkz. BOA, MD, 51, hk. 152 (14 Recep 991), 215 (1 Şaban 991).

96 BOA, $M D, 49$, hk. 323, 17 Cemaziyülevvel 991.

97 BOA, $M D$, 49, hk. 52, 23 Rebiyülevvel 991; Şam'da yaşanan kıtlıkla alakalı hüküm için bkz. BOA, $M D, 49$, hk. 477, 26 Cemaziyülahır 991.

98 BOA, $M D$, 52, hk. 71, 6 Ramazan 991.

99 BOA, $M D$, 52, hk. 395, 15 Zilkade 991.

100 Trablusşam muhafızı sıfatı ile kayda geçen tevcihatı için bkz. BOA, KK. d. 242, s. 48; Aynı dönemde Ali Paşa da Trablusşam beylerbeyi olarak tevcihat yapmaya devam etmiştir bkz. BOA, KK. d. 242, s. 24, 64, 96, 157.

101 BOA, KK. d. 242, s. 88, 124, 194, 200, 201; Aydın, Günalan, a.g.m., s. 150.

102 Cafer Paşa'nın beylerbeyi olarak Trabluşsam'da yaptığı muhtelif tevcihat için bkz. BOA, KK. d. 244, s. 33, 39, 43, 62, 70; BOA, KK. d. 245, s. 50, 104, 236.

103 Aralık 1585 tarihli bu hükümde Cafer Paşa'nın Trabluşsam valiliğinden çoktan azledildiği belirtilmelidir bkz. BOA, MD, 60, hk. 313, Evâsit-1 Muharrem 994.

104 Bahis geçen hükümde evvela Cafer Paşa'nın gayet intizamlı ve doğru bir tahrir yaptığını mektup göndererek ifade etmesine mukabil yeni beylerbeyine tekrar tahrir yapmaması söylenir. Lakin hükmün devamında Paşa'nın ilk tahrirde nasıl usulsüzlükler yaptığını ifade etmesi üze- 
beylerbeyliğinden azledilen Cafer Paşa'ya herhangi bir ceza verilmemiş, aksine yanındaki cebelüleri hazır edip sefere çıkan Serdar Özdemiroğlu Osman Paşa'nın ordusuna katılması emredilmiştir. ${ }^{105}$ Cafer Paşa azledildiğini öğrendiğinde sefere teveccüh edeceğini hükümete bildirmiştir. Gönderilen cevapta ademlerini dağıtmayıp süratle orduya katılması tekrar hatırlatılmıştır. ${ }^{106}$ Tebriz seferine katılan Cafer Paşa'nın hayatında artık yeni bir dönem başlayacaktır.

\section{Tebriz'in Fethi (1585) ve Şehrin Muhafazasında Hadım Cafer Paşa'nın İlk Seneleri}

Şirvan'da geçen zahmetli beş senenin ardından Özdemiroğlu Osman Paşa İstanbul'a dönmüş̧ür (Nisan 1584). Serhadde kazandığı zaferlere yaraşır bir törenle başkentte ağırlanan Paşa çok geçmeden sadrazam olmuştur. Ne var ki askerî sahadaki başarıları sebebiyle yükseldiği mevki ve Sultan III. Murad'dan gördüğü itibar başkent ricalini rahatsız etmiştir. Bunun neticesinde onun hakkında bazı asılsız iddialar yayılmıştır. Durumdan huzursuz olan Osman Paşa da III. Murad ile görüşerek sefere çıkmak istediğini söylemiştir. O sırada Serdar Ferhad Paşa'nın komutasındaki Safevi seferi devam ettiği için Osman Paşa Kırım'da süregiden iç savaşa müdahale etmek üzere görevlendirilir. Ancak, sefer için uygun olmayan bir zamanda İstanbul'dan ayrılmış; havalar kötüleşince Kastamonu'da kışlamak zorunda kalmıştı. Bu esnada Kırım tahtı için desteklenen İslam Giray acil yardım isteyince, Osman Paşa eski Bosna beylerbeyi Ferhad Paşa'yı göndermiş ve Ferhad Paşa'nın başarılı faaliyetleriyle Kırım meselesi çözüme kavuşmuştu. Asıl vazifesini halledince Osman Paşa, Tebriz'i fethetme tasarısını III. Murad'a sunmuştur. Bunun üzerine Ferhad Paşa İstanbul'a çağrılarak kendisi Acem seferinin yeni serdar ve sadrazamı tayin edilmiştir. ${ }^{107}$

Osman Paşa, Tebriz seferi için evvela Erzurum'da Ferhad Paşa'dan serdarlığı devralmıştır. Ardından, sefere katılacak beylerbeylerinin eyalet birlikleriyle ordugahta toplanmasını beklemiştir. Bütün hazırlıklar tamamlandıktan sonra serdar harekete geçmiştir. Tebriz'e giden yolda Safevi kuvvetleriyle karşılaşan Osman Paşa bu çatışmadan zaferle ayrılmıştır. Düşmanın mağlubiyeti, Tebriz'in fethini de kolaylaşmıştır. Kısa süren bir kuşatma akabinde Osmanlı

rine meselenin Osman Paşa'ya danışılması emredilir bkz. BOA, $M D$, 59, hk. 258, 9 Cemaziyülevvel 993.

105 BOA, $M D$, 58, hk. 242, 17 Cemaziyülevvel 993.

106 BOA, $M D, 59$, hk. 258, 11 Recep 993.

107 Osman Paşa'nın başkentteki serüveni ve Tebriz seferine çıkma süreci için bkz. Emirhan Özçelik, "İmparatorluk Yönetiminde Savaşların Etkisi ve Osmanlı Paşaları (1566-1606)", (Yayınlanmamış Yüksek Lisans Tezi), Bahçeşehir Üniversitesi, İstanbul, 2020, s. 83-87. 
ordusu şehre girmiştir (Ağustos 1585). Fethin ardından Osman Paşa, Tebriz'de muhtelif imar işlerini ve dış kale yapımını başlatmıştır. Bir süre sonra bu defa Safevi birlikleri Osmanlılara karşı saldırıya geçmiştir. Cigalazâde Sinan Paşa komutasında ve Tebriz önünde gerçekleşen çatışmalarda Osmanlı birlikleri iki defa yenilgiye uğramıştır. Hadım Cafer Paşa da bu çatışmalara katılmıştır. Sağlığ 1 iyice kötüleşen Osman Paşa askerin de taşkınlık çıkarmasıyla ricat etmeye karar vermiştir. Hastalığı sebebiyle, ordu yönetimini Cigalazâde Sinan Paşa devralmıştır. Ricatten hemen önce Tebriz'in muhafazasına kimin bırakılacağı da kararlaştırılmıştır. Büyük olasılıkla Sinan Paşa'nın tavsiyesi üzerine bu zorlu vazife için Hadım Cafer Paşa tercih edilmiştir. Osman Paşa'nın huzuruna çıkan Cafer Paşa'ya Diyarbakır beylerbeyliği ile Tebriz muhafazası tevcih edilmiş ve hil'at giydirilmiştir. ${ }^{108}$

108 Osman Paşa'nın Tebriz seferi ve fetihten sonra yaşananlar için bkz. Kütükoğlu, Osmanll-İran, s. 145-164; Şeyh Vefâyi Mehmed kaleme aldığı eserde Tebriz seferini ve daha sonra Cafer Paşa'nın Safevi kuşatmasını detaylı anlatmıştır şimdilik bkz. Şeyh Vefâyi Mehmed, Tevârih-i Gazavât-ı Sultan Murad-ı Sâlis, ÖNB Department of Manuscripts and Rare Books, Cod. H. O. 66, vr. 1a-13a; Âsafî’ye göre Osman Paşa hasta yatağında iken Cafer Paşa'yı gözüne kestirmiş, ondaki erliği görmüş ve Tebriz muhafazasını kendisine teslim etmiştir bkz. Âsafî, a.g.e., vr. 278a-279a; Minadoi zeki ve zalim bir yönetici olarak tanıttığı Cafer Paşa'nın Osman Paşa'ya hayran olduğunu yazmıştır bkz. Giovanni-Tomasso Minadoi, The War Between Turks and The Persians: Conflict and Religion in the Safavid and Ottoman Worlds, çev. Abraham Hartwell, London, I.B. Tauris, 2019, s. 185, 217. 


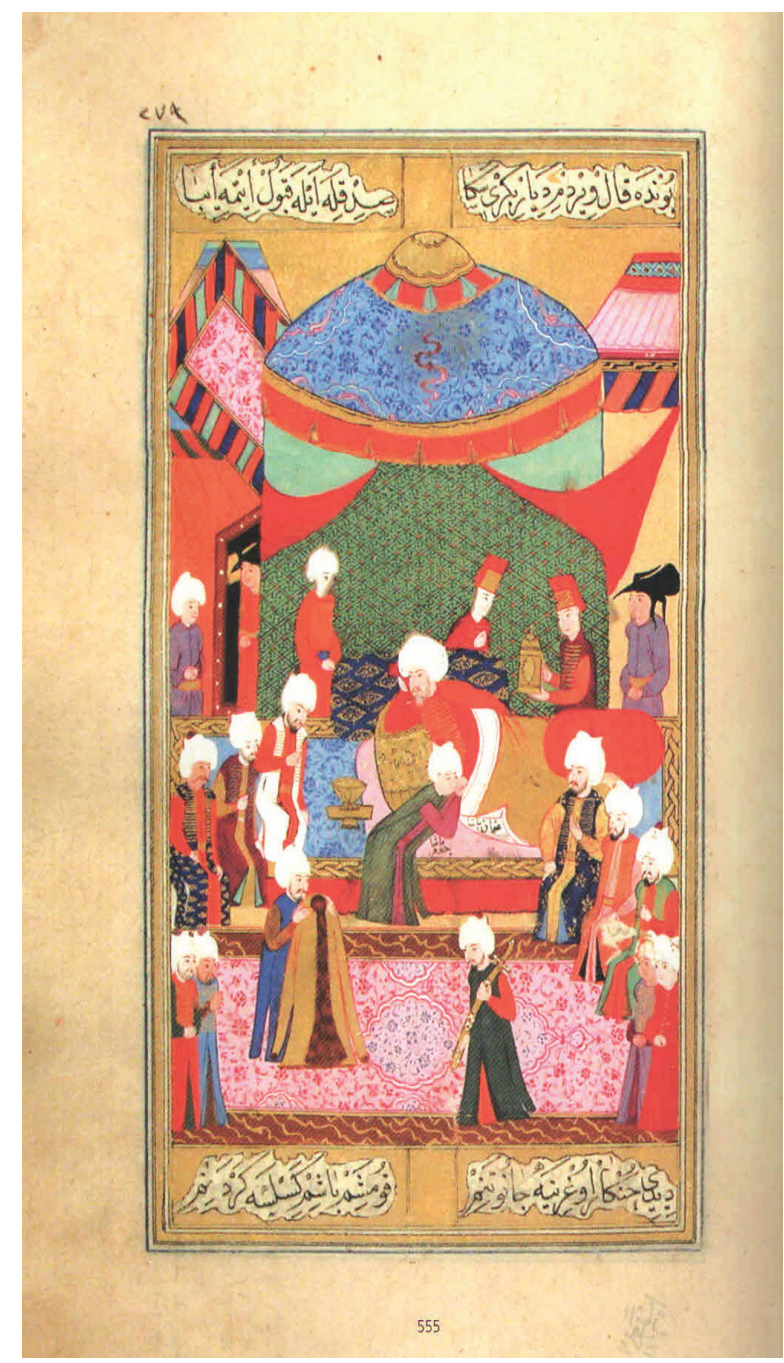

Minyatür 2. Özdemiroğlu Osman Paşa'nın Hadım Cafer Paşa'yı Tebriz Muhafazasıyla Görevlendirmesi, Şecâ'atnâme, İÜ Nadir Eserler Kütüphanesi TY, n. 6043 , vr. 279a

Özdemiroğlu Osman Paşa bu tayinden kısa bir süre sonra vefat eder. Ordugahta cenaze töreni düzenlenir. Ardından Osmanlı ordusu Cigalazâde Sinan Paşa'nın komutasında Tebriz'den ayrılır. Safevi birliklerinin ciddi tehdidi altında ordu ricat ederken aynı şekilde oldukça tehlikeli bir durumda bırakılan Tebriz ve Hadım Cafer Paşa'ya yeteri kadar asker ve levazım takviyesi yapılır. Üç bin beş yüz asker, birkaç yüz darbzen ve kul mevacibi için akçe şehirde bırakılır. Si- 
nan Paşa, Cafer Paşa'ya doksan güne kadar takviye birlik göndereceğine de söz verir. ${ }^{109}$ Sancakbeyleri, alaybeyleri, zuamâ, timar, kapıkulu askerlerinden oluşan garnizonun düşman karşısında disiplinini yitirmesine mani olmak için Paşa'ya bazı yetkiler tanınır. Askerlerin firar etmeleri halinde dirliklerini alıp üç yıllık mahsullerini miri adına zapt etmesine ve muhafaza hizmetine kalan yarar kimselere boşta kalan tımar ve zeametleri dağıtmasına müsaade edilir. ${ }^{110}$ Kayda değer bir askerî tecrübesi olmayan, hatta doğru düzgün savaş görmemiş Cafer Paşa için Tebriz'i idare etmek oldukça sanc1lı geçecektir. Özellikle muhafazadaki ilk yılında Safevilerin on bir ay boyunca şehri kuşatması onun birçok güçlükle mücadele etmesini gerektirecektir.

Osmanlı ordusunun çekilmesinin ertesi gününden itibaren Cafer Paşa'nın zorlu mesaisi başlar. Divan düzenleyip yeniçeri, sipahiler, silahdar ve diğer kapıkulu askerleriyle Tebriz'i korumanın müşkül olacağını hatırlatır. Safevilerin saldırısı kaçınılmazdır. Bu sebeple kapıkulları şehrin kapılarını kapar ve garnizondaki askerlerin firar etmelerine mani olur. Diğer taraftan ricat eden Osmanlı ordusu, Şah Muhammed Hüdabendi ve oğlu Hamza Mirza'nın emrindeki Safevi birliklerinin saldırısına uğrar. Cigalazâde Sinan Paşa, Safevi ordusunu püskürtür. Bu esnada Cafer Paşa kalenin surlarına şahî ve darbzenler dizdirir. Düşmanı engellemek için metrislere büyük taşlar yığar. Ardından askerleri alay alay hazırlayıp şehre çıkarır ve Tebriz halkına Osmanlı hakimiyetini askerî ritüellerle sergiler. Reayadan silahı olanları da Osmanlılara yardım için hazır eder. Şehir içinde bulunan Emir Han sarayını da karargah haline getirir. Bütün hazırlıklarını yapan Cafer Paşa artık düşman saldırısını bekleyecektir. ${ }^{111}$

Kasım 1585'de Safevi ordusunun Tebriz etrafına yerleşmesiyle yaklaşık on ay sürecek abluka başlar. Bütün kollardan şehri kuşatmak isteyen düşman askerleri ilk esnada Osmanlıları Tebriz kalesine sığınmaya mecbur eder. Safeviler taşrayı ele geçirdikten sonra dört koldan kale surlarına gedik açmak ve harap etmek için lağım ve metrisler kurar. Kayda değer bu ilk askerî tecrübesinde acemilik göstermemek adına Cafer Paşa alınacak önlemler için kaledeki zabitlerle sık sık meclis toplantı yapar. Özellikle sipahiler ağası ve yeniçeriler ağasının tecrübelerine güvenerek onların kararları doğrultusunda hareket eder. Osmanlı müdafileri küçük gruplar halinde ani huruç ve baskınlarla düşman metrislerine zayiat verdi-

109 Kütükoğlu, a.g.e., s. 160-161; Diğer kaynaklara kıyasla kuşatma günlüğünü kaleme alan Vefâyi daha doğru bir tespitle kalede hepsi tecrübeli üç bin beş yüz askerin olduğunu yazmıştır bkz. Vefâyi, a.g.e., vr. 15b-16b, $27 \mathrm{~b}$.

110 BOA, $M D, 59$, hk. 348, 16 Zilkade 993.

111 Cafer Paşa'nın şehirde ilk günleri ve ricat eden Osmanlı ordusu ile Safevi birlikleri arasındaki savaşi için bkz. Vefâyi, a.g.e., vr. 17a-24a. 
rir. Huruçlar esnasında surların üstünden top ve tüfeklerle açılan ateşle Safevilerin çoğu zaman karşı saldırısı engellenir. Ayrıca Safevilerin kale içine kadar genişlettikleri büyük bir lağım etkisiz hale getirilir. Açılan surun belli kısımlarında açılan gedikler Osmanlı askerlerinin gece ve gündüz çalışmalarıyla tamir edilir. Böylece kuşatmanın ilk iki aylık dönemi Cafer Paşa ve müdafilerin uyumlu ve düzenli faaliyetleri sayesinde başarılı geçer. ${ }^{112}$

Ablukanın başlamasından henüz haberdar olmayan fakat Safevi birliklerinin Tebriz'i hedeflediğini öğrenen Osmanlı hükümeti, gerek Cafer Paşa gerekse Cigalazâde Sinan Paşa ve bölgedeki diğer beylerbeylerinden son durum hakkında bilgi edinmeye çalışmaktaydı. Bilhassa Cafer Paşa'dan Safevi ordusu ve askerlerinin düşman karşısında mukavemet gösterme ihtimaline dair malumat vermesi istenmekteydi. ${ }^{113}$ Padişahın fermanlarının şehre ulaştı̆̆ 1 vakitlerde kuşatmanın seyrini değiştirecek önemli gelişmeler yaşanmıştır (Şubat 1596). Evvela Osmanlı ordugâhında gıda fiyatları pahalanmış ve zahire sıkıntıları artmıştır. ${ }^{114}$ Kesilen akçeden memnun olmayan askerler paşayı sıkıştırmış ve istekleri gözetilmiştir. Gözünden yaşadığı rahatsızlığ atlatan Cafer Paşa da askeri etrafına toplamış ve Safevi birliklerine baskın düzenleyerek erzak ve sair ihtiyaçlarını temin etmiştir. Hatta Van'da bulunan Sinan Paşa'yı da planına dahil etmeye çalışmıştır. ${ }^{115}$

Bir yandan şehirdeki askeri teskin ve memnun etmeye uğraşan Cafer Paşa bir yandan da askerî ihtiyaçların tedariki için o sıralar Van'da olan Cigalazâde Sinan Paşa ile doğrudan hükümete başvurmuştur. Daha kış ayında başkente takrir yazıp barut, zahire ve asker takviyesi talep etmiştir. Merkezden gelen cevapta, bölgenin işlerinin Sinan Paşa'ya havale edildiği, taleplerinin karşılanması için onunla haberleşmesi gerektiği bildirilmiştir. ${ }^{116}$ Diğer taraftan, merkez Sinan Paşa'dan gelen bilgileri de dikkate alarak Serdar Ferhad Paşa'yı Tebriz'deki gelişmeleri takip etmesi konusunda uyarmıştır. ${ }^{117}$ Cafer Paşa da Ferhad Paşa'yla iletişime geçmiştir; Mart 1586'da orduyla İstanbul'dan ayrılan serdar Sivas'a vardığında Paşa'nın adamları ile karşılaşmıştır. Cafer Paşa Hamza Mirza'nın güçlü bir orduyla saldırıya hazırlandığını haber vererek serdardan hemen destek kuvvetleri göndermesini

112 Vefâyi, a.g.e., vr. 25a-61b.

113 Cafer Paşa'ya Şah'ın ve oğlunun ordunun başında olup olmadığı, askerlerinin hali, düşmana direnme şansı gibi pek çok soru sorulmuştur bkz. BOA, $M D$, 60, hk. 227; Benzer içerikte Sinan Paşa ve bölgedeki beylere gönderilen hüküm için bkz. BOA, $M D, 60$, hk. 273; İki hükümde muhtemelen 993 senesinin son ayında kaleme alınmıştır.

114 Vefâyi, a.g.e., vr. 73a-74a.

115 Âlî, Künhü'l-Ahbâr, vr. 555b-556b; Minadoi, a.g.e., s. 234-235.

116 BOA, $M D$, 60, hk. 379, 410; ayrıca bkz. Kütükoğlu, a.g.e., s. 167.

117 BOA, $M D, 60$, hk. 685, Evâsit-1 Cemaziyülevvel 994. 
istemiştir. Çünkü Osmanlı yardımcı kuvvetlerinin şehre vasıl olması düşmanın gözünü korkutacaktır. ${ }^{118}$

1586 kışında gerçekleşen diğer bir önemli gelişme ise savaşın başında Osmanlılara itaat eden Türkmen ve Tekelü birliklerinin Safevi ordugâhına gelerek taraf değiştirmeleri olmuştur. Rakip ordunun yeni askerlerle güçlenmesi Osmanlı askerlerini dehşete düşürmüştür. Hatta bir rivayete göre, müdafiler Cafer Paşa'nın kafasını kesip düşmana teslim etmeyi ve bunun karşılığında zarar görmeden Tebriz'den ayrılmayı dahi düşünmüştü. Karşı tarafa katılan Türkmenler ise Cafer Paşa'ya mektup göndererek teslim olmasını istemiştir. Fakat Paşa askerlerinin direncini kırmamak için onları cesaretlendirmiş ve kışın son günlerinden itibaren daha büyük huruçlar düzenlenmiştir. Cafer Paşa'yı esas rahatlatan gelişme ise, Safevi ordusuna katılan bu kırk bin kadar Türkmenin asıl niyetlerinin ortaya ç1karmasından sonradır. Türkmen ve Tekelüler, Hamza Mirza'ya itaatlerini bildirip daha sonra ihanet ederek Kazvin'e yönelmiş ve burada Şehzade Tahmasb'1 tahta geçirmiştir. Ortaya çıkan saltanat krizine müdahale etmek için Hamza Mirza kuşatma ordusunun büyük kısmını toplayarak Kazvin'e dönmüştür. Zorlu geçen mücadelelerin sonunda Hamza Mirza Türkmenleri yenecek ve taht değişikliğini geçersiz kılacaktır. Fakat bu esnada Tebriz kuşatmasını feda edecektir. ${ }^{119}$

Hamza Mirza'nın ayrılmasından sonra Safevi han ve sultanları baharın da gelmesiyle kuşatmanın şiddetli geçen son evresine hazırlanır. Bu meyanda altmış kıyye taş atan iki adet güçlü top kurulur (Nisan 1586). O vakte kadar görülmemiş evsaftaki bu toplar kalenin surlarında büyük tahribata yol açar. Safevilerin ateş gücünü arttırması Osmanlı askerlerinin moralini bozar; ancak, iyi organize edilen bir atakla düşmanın büyük toplarından biri ele geçirilir. Safevi kroniklerinde kaybedilen bu top kuşatmanın başarısız olmasında temel sebeplerden biri olarak kabul edilir. Zira bu kayıp Safevilerin moral üstünlüğünü kaybetmesine neden olmuştur. Hava sıcaklığı nedeniyle şehir önünde yeni toplar da dökülememiştir. Bahar ayları Safevi birliklerinin şehrin farklı kısımlarına karşı şiddetli saldırıları ve Osmanlıların bu hücumları püskürtmesiyle geçer. Van'dan gelecek yardımdan umudu kesmiş olmalarına rağmen Cafer Paşa'nın cesaretlendirmesi ve bölük ağalarının bireysel çabaları ile Osmanlı müdafileri düşman ordusuna on kadar başarılı huruç gerçekleştirilir. Düşmanın umutlarını bu saldırılarla kıran Osman-

118 Minadoi, a.g.e., s. 237.

119 Türkmenlerin Tebriz'e varması ve daha sonra gerçekleşen gelişmelerle alakalı bkz. Vefâyi, a.g.e., vr. 63a-77a; Don Juan of Persia: A Shi'ah Catholic, 1560-1604, haz. G. Le Strange, London, Harper \& Brothers, 1926, s. 194-202; Eskandar Beg Monshi, History of Shah 'Abbas the Great (Tarik-e 'Alamara-ye Abbasi), haz. Roger M. Savory, Colorada, c. I, Westview Press, 1930, s. 455-480. 
lılar, ayrıca casuslar sayesinde sık sık karşı tarafın planlarından da haberdar olur. Zamanla müdafiler Tebriz kalesi dışında düşmanın metrislerini ve şehrin bazı mahallerini ele geçirmeyi başarır.

Kuşatmanın kötüye gittiğini öğrenen Hamza Mirza önce bazı destek birlikleri gönderir. Osmanlıların etkili huruçları yüzünden bu destek birliklerinin kuşatmay1 sürdüren Safevi askerlerine pek katkısı olmaz. Diğer taraftan Cafer Paşa, zahire sorunları yaşayan ve uzun süren kuşatma yüzünden sayıları azalıp takatsizliği artan askerlerini dinç tutmaya büyük çaba harcar. Teşvik edici konuşma ve vaatlerle direnmekten başka şansı olmayan müdafileri cesaretlendirir. Bunun neticesinde Osmanlı garnizonu Temmuz 1586'da ordu ile Tebriz'e gelen ve abluka için şehir etrafinda bulunan Safevi birlikleriyle birleşen Hamza Mirza'nın gerçekleştireceği genel saldırılara karşı koyabilmiştir. Safeviler yaz biterken kaleyi süregiden yöntemlerle alamayacaklarını anlar. Zira kaleden çıkan Osmanlılara karşılık verseler dahi kayıpları artmakta ve ileri hatları zayıflamaktadır. Ağustos'un başından itibaren farklı kollardan başlatılan saldırılardan da sonuç alınamayınca Hamza Mirza genel bir hücum yapılmasına karar verir. Ağustos'un ortasından itibaren birkaç kez düzenlenen yürüyüşler Cafer Paşa'nın da ön saflarda katıldığı mücadeleler neticesinde Safevilere pahalıya patlar. Günlerce devam eden çatışmaların ardından Hamza Mirza Tebriz'i düşüremeyeceğini kabullenir. Sıkıntıları artan ve pek çok önemli ismini kaybeden Safevi ordusu son bir kez şehri harap eder ve Tebriz'i terk eder (Eylül 1586). ${ }^{120}$

Cafer Paşa komutasındaki askerlerle zorlu koşullar altında Safevilere direnirken, Osmanlı merkezi Tebriz'e geç kalan yardımın ulaştırılması için bölgedeki paşaları sıkıştırmaktaydı. Ağustos 1586'da Cigalazâde Sinan Paşa'ya Van ve Diyarbakır askerlerini toplayarak acilen Tebriz'e gitmesi emredilmiştir. Serdar Ferhad Paşa'dan da Tebriz'deki son gelişmeler hakkında istihbaratı başkentte iletmesi istenmiştir. ${ }^{121}$ Neticede Sinan Paşa tarafından şehre herhangi bir destek gönderilmemiştir. Serdar ise kuşatma bittikten sonra Tebriz'e varabilmiştir. Orduyu hazırladıktan sonra Erzurum'dan harekete geçen Ferhad Paşa önce Tebriz yolu üzerinde bulunan Hamana Kalesi'ni fetheder. Serdar, bir süre kalenin tamiratıyla uğraşır. Daha sonra yürüyüşüne devam eder ve üçüncü konakta Tebriz'e varır. Kendisi şehre sadece bir kere girer ve düşman tehdidinin henüz geçmediğini

120 Kuşatmanın bahar ve yaz aylarında gerçekleşen hadiselerin detaylı anlatımı için bkz. Vefâyi, a.g.e., vr. 82a-168b; ayrıca bkz. Âlî, Künhü'l-Ahbâr, vr. 556b-557a; Minadoi, a.g.e., s. 240241; Don Juan of Persia: A Shi'ah Catholic, s. 188-193; Eskandar Beg Monshi, a.g.e., c. I, s. 451-455; Selânikî, a.g.e., c. I, s. 177-178; Kütükoğlu, a.g.e., s. 164-165.

121 BOA, MD, 61, hk. 72, 12 Ramazan 994; Ayrıca bkz. Kütükoğlu, a.g.e., s. 168. 
düşündüğü için orduyu surların dışında bırakır. Otağını varoşta kurar ve Cafer Paşa ile burada görüşür. Zaferi kutlamak için şehirde merasimler düzenleyen Cafer Paşa bu sırada serdarın huzuruna da çıkmış olur. Ferhad Paşa vakit kaybetmemek adına kalenin kuşatma boyunca harap olan yerlerini üç dört gün içinde tamir ettirir. İkametini olabildiğince kısa tutan serdar, gerekli teçhizat, zahire ve askeri tedarikini yaptıktan sonra Tebriz'den ayrılır (Eylül 1586). ${ }^{122}$

Ferhad Paşa'nın kısa süren bu Tebriz ziyaretinde Paşa'ya altı bin muhafız asker, bolca zahire ve iki yüz yirmi dört yük akçe tahsil ettiği hükümlere yansımıştır. Ne var ki Cafer Paşa tahsis edilenlerin miktar ve mikyasından pek de memnun olmamıştı. Bırakılan zahirenin kifayet etmeyeceğini ve tahsis edilen paranın da üç kıst mevacibe ancak yeteceğini hükümete bildirmişti. Bunun üzerine, önce Serdar Ferhad Paşa'dan Cafer Paşa'ya reayayı adaletle idare edip zahire sağlamaları için onlara zarar vermemesini ögütleyen bir mektup yazması istenir. Bizzat Cafer Paşa'ya yazılan hükümde ise, Tebriz etrafında büyük kasaba ve köylerin olduğunu, Tebrizlilerden de bin kader hanenin tekrar şehre dönüp yerleştiği belirtilerek, ihtiyaç duyulan zahirenin bunlardan temin edilebileceğine dair kaynak gösterilmiştir. Bunun için, reayaya istimâlet vermeli, askerini adil bir ticarete teşvik edip halkın itimadını kazanmaya gayret göstermeliydi. Böylece satılmak için çokça zahire şehre gelecekti. Gelen malları israfının önüne geçmesi de gerekecekti. ${ }^{123}$

Muhafazadaki ilk senesinde elindeki çok az kuvvetle Safevi kuşatmasına direnen ve muhtemelen kendisinden umulmayan bir şekilde Tebriz'i koruyan Cafer Paşa'dan zaferini pekiştirmesi beklenmiştir. Bu maksatla, önce bizzat III. Murad tarafindan Tebriz halkı ve ileri gelenlerine Safevilere yardım etmiş olmalarına rağmen adaletle muamele edileceği sözü verilmiştir. Sultan, ahaliden cezaland1rılma korkusuyla Tebriz'den ayrılmamalarını öğütlemiş ve artık Osmanlı tebaası sayıldıkları için Cafer Paşa'nın herhangi bir zulme yeltenmeyeceğini garanti etmiştir. Cafer Paşa da kuşatmada dağılan ahaliye istimâletler yazıp, onları tekrar şehre geri dönmeye teşvik edecektir. ${ }^{124}$ Halkın güvenini kazanıp düzeni tesis etmesine yönelik alınan bu tedbirlerin akabinde Cafer Paşa'ya şehirdeki askerî yönetimden kendisinin mesul olduğu hatırlatılmıştır. Öyle ki Ferhad Paşa'nın Tebriz

122 Vefâyi, a.g.e., vr. 170a-174a; Âlî, Künhü'l-Ahbâr, vr. 557-557b; Selânikî, a.g.e., c. I, s. 174175; Harimî, Kitâb-ı Gencîne, s. 26-27

123 BOA, MD, 61, hk. 288 (5 Muharrem 995), hk. 289 (2 Muharrem 995); Aynı hükümleri Kütükoğlu da kullanmıştır bkz. Kütükoğlu, a.g.e., s. 169; Hima beyine gönderilen hükümde de Cafer Paşa ile irtibatını koruması ve bölge halkına asla zarar vermemesi emredilmiştir bkz. BOA, $M D, 61$, hk. 290, 2 Muharrem 995.

124 BOA, $M D, 62$, hk. 18 (2 Safer 995), 14 (2 Safer 995). 
yardımını da özetleyen uzun bir hükümde ona şehir ve civarında harp olmadığı için askere terakki verilmeyeceği bildirilmiştir. ${ }^{125}$ Benzer bir şekilde serdara yazılan hükümde de Cafer Paşa'nın israfına hazine yetmeyeceği söylenmiştir. Bu nedenle serdara Cafer Paşa için terakki ve iptidaların padişah tarafından kabul edilmediğini bildiren bir mektup yazıp göndermesi emredilmiştir. ${ }^{126}$

Her ne kadar ilk esnada şikayetler ve buna verilen cevaplar üzerinden iletişim şekillenmişse de III. Murad Cafer Paşa'nın başarısını göz ardı da etmemiştir. Yazdığı uzunca fermanda, Şah ile Şah'ın oğlunun idaresindeki orduya Tebriz'de gösterdiği mukavemet ve nihayet kazandığı zafer için onu kutlamıştır. Bir müzehheb kılıç ile hil'at ile Paşa'yı onurlandırmış; Tebriz askeri ile uyum halinde muhafaza vazifesini adına yakışır bir şekilde sürdürmesini temenni etmiştir. ${ }^{127}$ III. Murad sadece övgüyle yetinmemiş, Cafer Paşa'nın rütbesini de yükseltmiştir. Paşa, Diyarbakır beylerbeyliğinden alınarak vezaret ile Van beylerbeyliğine terfi edilmiştir (Aralık 1586). ${ }^{128}$ Diğer taraftan kuşatmadan sonra Safevilerin sulh talebi ve elçi irsali teşebbüsleri nedeniyle Cafer Paşa'nın askerî ve siyasî faaliyetlerine kısıtlama ve denetleme getirilmiştir. Aslında Tebriz'e gönderilen hazineye dair hükümlerde Paşa'ya düşmanın barış için elçi yollama hazırlığından bahsedilmiştir. 1587'nin bahar ayında Şah'ın mirzalarından birisini İstanbul'a göndereceği hakkında duyumlara dair ona da haber verilmiştir. Bu nedenle karşı taraftan kendisine gönderilen mektupları başkentte ulaştırması istenmiştir. Sulhun gündemde olduğu bu dönemde barışı tehlikeye atacak herhangi bir saldırıdan men edilmiştir. ${ }^{129}$ Fakat en sonunda beklenildiği gibi elçi gelmeyeceği gibi Cafer Paşa Tebriz'de bir kez daha Safevilere karşısında büyük bir savaş verecektir. Dahası hasımla olduğu kadar Tebriz'de mütemekkin askerlere karşı da gayet çetin bir mücadeleye girecektir.

\section{Hadım Cafer Paşa'nın Tebriz'de Tedirgin Yılları}

Acem coğrafyasının en büyük şehirlerinden biri olan Tebriz uzun yıllar Akkoyunlular ve Safevilere başkentlik yapmıştır. Özellikle İpek Yolu üzerindeki konumu yüzyıllarca kozmopolit bir nüfus barındırmasına ve zengin bir ticaret şehri olmasına zemin hazırlamıştır. Tebriz'in idari ve ticarî önemi nedeniyle yine

125 BOA, $M D, 62$, hk. 16, 2 Safer 995.

126 BOA, $M D, 62$, hk. 24, 2 Safer 995.

127 BOA, $M D, 62$, hk. 46, 19 Rebiyülevvel 995.

128 Selânikî, a.g.e., c. I, s. 177.

129 Ayrıca bu hükümde Cafer Paşa'ya serhad ahvalinin cümleten Serdar Ferhad Paşa’ya tevdi edildiği bu sebeple mansıp atamalarına kadar her şeyden serdarı haberdar etmesi istenmiştir bkz. BOA, MD, 62, hk. 29, 5 Rebiyülevvel 995. 
yüzyıllar boyunca farklı devletlerin hakimiyeti altına girmiş ve fizikî yapısı çeşitli evrelerden geçmiştir. ${ }^{130} 1502$ 'de Şah İsmail'in önderliğinde teşekkül eden Safevi Devleti'nin başkenti olduktan sonra da idarî ve mimarî değişimler yaşayan şehrin hikayesinde Osmanlıların sahneye girmesiyle yeni bir sayfa açılmıştır. I. Selim bir ve I. Süleyman iki defa Tebriz'i işgal etmiş fakat iki padişah da şehirde kalıcı bir hakimiyet tesis edememiştir. Öte yandan Osmanlı saldırıları şehrin idarî ve ticarî yapısında kırılmalara yol açmıştır. Özellikle I. Selim'in Safevi seferinden önce uygulamaya koyduğu ipek ticareti boykotu ipek üretimi ve ticaretinin yoğun yapıldığ 1 Tebriz'in ekonomik hayatını sarsmıştır. I. Süleyman bu ambargoyu gevşetse dahi iki defa saldırması nedeniyle şehirdeki ticaret eski canlılığını yitirmiştir. ${ }^{131}$

Şah Tahmasb Osmanlı saldırılarına hedef olmasını gerekçe gösterip başkenti Kazvin'e taşımıştır. İdarî statüsünü de kaybeden Tebriz'de bütün bu kötüye gidiş halk ve askerî kesimin memnuniyetsizliğini arttırmıştır. Öyle ki şehirde bulunan askerler çok uzun seneler maaşlarını alamamıştır. Hükümetin denetimini azaltmasına koşut şehir yöneticilerinin halka karşı haksız işlemleri yaygınlaşmıştır. Gerek askerî gerek ticari sınıftan pek çok kişi kötü şartları gerekçe gösterip şehirden ayrılmıştır. Zayıflayan otorite ve artan usulsüzlüklerin yanı sıra, ticarî faaliyetlerin sekteye uğramasına rağmen vergilerin arttırılması ise en sonunda ciddi bir isyana yol açmıştır. 1571-1573 arasında bilhassa şehirdeki tacirlerin öncülügünnde ayaklanmalar gerçekleşmiştir. Neticede Şah Tahmasb'ın müdahalesiyle asiler teskin edilmişse de gelişmeler şehir ahalisinin devlete bağl1lığını zayıflatmıştır. ${ }^{132}$ İsyandan birkaç y1l sonra başlayan seferlerde Tebriz valisi Osmanlılarla iletişime geçerek Safevi hükümetine karşı duyulan rahatsızlığı ayyuka çıkarmıştır.

130 Tebriz'in tarihi ile ilgili genel bazı okumalar için bkz. Sheila S. Blair, "Tabriz: International Entrepôt under the Mongol", Politics, Patronage and the Transmission of Knowlodge in the 13th-15th Century Tabriz, ed. J. Pfeiffer, Leiden, Brill, 2014, s. 321-356; Patrick Wing, "Rich in Goods and Abounding in Wealth: The Ilkhanid and Post-Ilkhanid Ruling Elite and the Politics of Commercial Life at Tabriz, 1250-1400", Politics, Patronage and the Transmission of Knowlodge in the 13th-15th Century Tabriz, s. 301-320; Lida Balilan Asl, "The spatial structure of Tabriz in Safavid era in comparison with itineraries and pictorial documents", Bagh-e Nazar, cilt 13, say1 38, 2016, s. 45-56.

131 Meseleyle alakalı yazılan kapsamlı çalışmalara atıfla yapılan genel bir değerlendirme için bkz. Dilaver Azimli, "Safevi-Osmanlı İlişkilerinde Doğu Anadolu Meselesi (Ekonomik Yönden)", Uşak Üniversitesi Sosyal Bilimler Dergisi, cilt 3, sayı 2, 2010, s. 100-114.

132 Zahrasadat Keshavarz - Asghar Montazerolghaem - Shabnamsadat Hashemi, “Assessing the Causation of Tradesmen Rebellion in Tabriz Through Institutionalisation Approach During Shah-Tahmasp Safavi Ruling (1571-1573 AD)", Iran: Journal of the British Institute of Persian Studies, 2021, s. 1-11 (https://doi.org/10.1080/05786967.2021.1882262). 
Safevi seferleri öncesinde Osmanlıların alternatif fetih tasarılarında Tebriz yer almıştır. Şehre çok yakın olan Van beylerbeyinin düşmanın durumuna dair gönderdiği raporlar ve Safevilerin Tebriz-Van etrafında yağmaları savaşı tetikleyen gelişmelerden biri sayılmıştır. Bu nedenle sefer planlarının tartışıldığ mecliste öncelikle Tebriz'in fethedilmesi ve şehrin etrafındaki bölgenin tahkim edilerek hakimiyetin genişletilmesi gündeme alınmıştır. ${ }^{133}$ Seferlerin ilk senesinde Tebriz hakimi Emir Han taraf değiştirmeye ve Osmanlı hakimiyetini tanımaya niyetlenmiştir. Van Beylerbeyi ile iletişime geçen Emir Han, Safevilerin saldırı planlarını onunla paylaşmıştır. ${ }^{134}$ Tebriz hakiminin Osmanlılar için casusluk yaptığını öğrenen III. Murad kendisine bir nâme göndererek, Osmanlı Devleti’ne olan meyline mukabil mektup yazarak itaatini beyan etmesi halinde Tebriz'in idaresini kendisine bırakacağını bildirmiştir. ${ }^{135}$

Emir Han neticede III. Murad'in teklifini kabul etmemiştir. Ancak, hem davranışları hem de o vakte kadar vuku bulan hadiseler Tebriz ahalisinin Safevi hükümetine sadakatinin törpülendiğini göstermiştir. Yıllar sonra Özdemiroğlu Osman Paşa'nın şehri fethederken güçlü bir mukavemetle karşılaşmaması da Tebriz ahalisinin Osmanlı hakimiyetini benimseme temayülüne atfedilebilir. ${ }^{136}$ Dolay1sıyla Hadım Cafer Paşa şehrin seneler içinde Safevi hükümetiyle yaşadığı kötü tecrübelerin etkisini idarede bulunduğu sürece hissetmiş olmalıdır. Keza ileride görüleceği üzere, Paşa daha önceki fetihlere kıyasla Osmanlı idaresinin Tebriz'de kabul edilmesinde mesafe kat edebilmiştir. Fakat aynı süreçte seferlerin henüz bitmemiş olması şehrin askerî ve ekonomik sıkıntıları ve düşman karşısında teyakkuz halini bir süre daha canlı tutmuştur.

1587-1588 yılları arasında Cafer Paşa bir taraftan finansman açığını kapatmak için hazine desteği ve dağılan yerli halkın yeniden yerleşmesini beklerken diğer taraftan seferin gidişatını ve kendisine yönelik sonuçlarını takip etmiştir. Gelişmelerin askerî cephesi düşünüldügünde Safevilerin bahsedilen barış talebi nedeniyle serhad bir süre savaş ortamından kurtulmuştu. Serdar Ferhad Paşa, bu süreçte gerek düşmanın barış için adımlarını gerekse Acem vilayetlerinin itaat taleplerini başkente rapor etmiştir. Ne var ki sulh umutları fazla uzun sürmemiştir.

133 Minadoi, a.g.e., s. 15-16; Matthee, a.g.m., s. 9.

134 Emir Han Safevilerin Hoy, Urmi, Selmas yahut Van'a saldırma planlarının olduğunu Van beylerbeyine mektup yazıp bildirmiştir bkz. BOA, $M D$, 32, hk. 383, 384, 385, 24 Rebiyülahir 986.

135 BOA, $M D, 32$, hk. 507, 29 Zilkade 986.

136 Özdemiroğlu Osman Paşa'dan önce de Tebriz'i fethetmek için bazı hazırlıklar yapılmıştır. Özellikle şehrin zayıf noktaları ve nasıl fethedileceğine dair raporlar merkeze sunulmuştur. 1583'de Ferhad Paşa'ya Tebriz'e saldırmasına müsaade edilmiş, uygun görürse seferini buraya yapması söylenmiştir bkz. BOA, $M D$, 48, hk. 311; $M D$, 52, hk. 392. 
Kazvin'e gelip tahttı ele geçiren Şah Abbas kendi ülkesinde sulha rıza gösterip Osmanlılara mahkum olmayı kabul edenleri ortadan kaldırmıştır. ${ }^{137} \mathrm{Bu}$ gelişme üzerine Ferhad Paşa'ya yeni sefer için hazırlık emri verilmiştir.

Safevi tahtında yaşanan değişim Tebriz'de bulunan Cafer Paşa'yı da doğrudan etkilemişsir. Osmanlı hükümeti Aralık 1587'den itibaren Serdar Ferhad ve Cafer Paşa'ya birçok hüküm göndererek sınırdaki gelişmeler karşısında alınacak tedbirleri belirlemeye ve Tebriz'in durumunu yakından takip etmeye çalışmıştır. Gence ve Karabağ taraflarında kaleler inşa eden Ferhad Paşa, barış için Şah Hudabendi'nin mirzasını beklerken Horasan'dan gelen Şah Abbas'ın başkentte vardığı haberini almıştı. Bu umulmadık gelişme karşısında, Tebriz'in tehdit altına girdiğini düşünen hükümet, şehrin muhafazası için derhal harekete geçilmesini istemiş; serdara da ordusunu toplayarak Tebriz'e yakın yerde kışlaması emredilmiştir. ${ }^{138}$ Yine Cafer Paşa'dan gelen mektuplar üzerine Ferhad Paşa, Şah Abbas'ın saldırı planı hakkında bilgi toplaması için casuslar görevlendirmeye teşvik edilmiştir. Erdebil'de kışlayıp Tebriz'e zahire akışını kestiğine dair haberlerden sonra serdarın ayrıca Cafer Paşa ile iletişime geçip Şah'ın gerçekten bu şehri hedef alıp almadığını öğrenmesi elzem olmuştu. Her halükarda Tebriz'e yönelik harekâta hızlıca cevap verebilmesi için orduyu hazır tutması serdara tekrar hatırlatılmıştır. ${ }^{139}$ Bu konuda üst üste yazılan hükümlerde, Şah Abbas'ın kış1 fırsata çevirip ani bir saldırı düzenlemesine müsaade edilmemesi adına Ferhad Paşa dışında Hakkari ve Bitlis hakimleri de uyarılmıştır. ${ }^{140}$

Tebriz'e olası saldırılara karşı askerî hazırlıklar yapılırken, şehrin hazine ihtiyacı ve bunun doğurduğu sorunlar halledilmeye çalışılmıştır. Serdar Ferhad Paşa'ya gönderilen hükümlerde bir yıl üç aylık sürede şehirdeki kul mevacibi için üç yüz yetmiş dokuz yük akçe ve elli bin beş yüz elli akçe nakit ödendiği açıklanmıştır. Bu ödemeleri takviye etmek mümkün olsa bile asıl sorun zahire yetiştirilememesidir - ki bu durum Tebriz askerinin Van eyaleti sınırlarına yağma

137 Selânikî, a.g.e., c. I, s. 182, 185, 186-187.

13863 numaralı mühimme defteri 'min şehr-i Receb sene 995 ilâ evâhir-i Rebiyülevvel sene 996' arasında yazılan altmış beş adet hüküm ihtiva eder. Safevi tahtında yaşanan değişiklikten sonra sefer ve yeni durumla alakalı Serdar Ferhad Paşa ve Cafer Paşa'ya gönderilen hükümler gayet uzundur. Az hükümlü fakat nazik bir döneme karşılık geldiği için önemli bu mühimme defteri tez olarak çalışılmıştır. Burada hükümlere yapılacak atıflar hazırlanan tez üzerinde olacaktır. Ferhad Paşa'ya 23 Safer 996 ve 13 Muharrem 996'de gönderilen hükümler için bkz. Serdar Kar, “63 Numaralı Mühimme Defteri (995-996/1587-1588): Özet ve Transkripsiyon”, (Yayınlanmamış Yüksek Lisans Tezi), Marmara Üniversitesi, İstanbul, 2002, s. 19-21, 34-35.

139 Kar, a.g.t., s. 55-58.

140 Kar, a.g.t., s. 43-46; BOA, MD, 64, hk. 573, 29 Ramazan 996. 
akınları yapmasına sebep olmuştur. Askerlerin saldırıları nedeniyle Van'da dükkanlar kapanmış ve hayat durma noktasına gelmiştir. Bölgedeki yöneticilerden ulaşan raporlarda, bu konuda sorumluluk Cafer Paşa'ya yüklenmiş, hatta onun sulha rızası olmadığını iddia edilmiştir. Bunun üzerine serdara zahire ile hazine birlikte mühimmatı da hazırlanıp Tebriz'e ulaştırılması ve kimsenin kendi başına hareket etmeye yeltenmemesi emredilmiştir. ${ }^{141}$ Zahire sıkıntısı nedeniyle Tebriz askerinin usulsüz davranışlarından sonra Cafer Paşa da ayrıca ikaz edilmiştir. Şah Abbas'ın halen şehre saldırma ihtimali varken, Van'da yaşanan nahoş hadiseler hoş karşılanmamıştır. Cafer Paşa'dan askerlerin benzer bir hadiseye karışmasına müsaade etmemesi istenmiştir. Yeniçeri ve sipahilerin saldırıları yüzünden Tebriz'in Kızılbaş'a rağbet göstermesine katiyen izin verilmemeliydi. Paşa'ya o zamana kadarki hizmetine yakışır bir şekilde yönetimini sürdürme uyarısı yap1lırken, zahire ve hazine hususunda yapılan değişiklikler haber verilmiştir. Artık Van eyaletinde toplanan zahire Tebriz'e alınacak ve Diyarbakır'da nüzul bakayısından olan Van'a aktarılacaktır. Bundan sonra kul mevacibleri ise Bağdad ve Diyarbakır hazinelerinden karşılanacaktı. ${ }^{142}$

Serhadde çabuk değişen gündem ve Safevi tarafindan yeni gelen haberler Cafer Paşa'nın durumunu sürekli güncellemiştir. Nisan 1588'de Paşa, Özbek Abdullah Han'a karşı zafer kazanan Safevilerin Bağdad, Erzurum ve Tebriz tarafına askerler salacağına dair duyumlar almıştır. Merkezin bu konuda haberdar edilmesi üzerine Serdar Ferhad Paşa ile bölgedeki beyler ihtiyatlı olmaları için uyarılmıştır. Lakin barış görüşmeleri için halihazırda Safevilerin hazırlık yapması serhadden gelen bilgilerin etkisini azaltmıştır. Aynı hükümlerde Tebriz'de yaşanan kul mevacibi ve dirlik sıkıntısı hakkında yeni gelişmeler hususunda serdar bilgilendirilmiştir. Kul taifesi, maaşlarında otuz sekiz yük akçe bakiye varken ve Muharrem, Safer ve Rebiyülevvel mevacibleri gönderilmişken, karışıklık çıkarmıştır. Hatta kapıkulu ve diğerlerinin defterdarları iki defa serdara geri yollanmıştı. Bunun yanında Osman Paşa zamanında tımar ve zeamet sahibi olanlar Safevi kuşatması esnasında firar etmelerine rağmen şimdi dönüp üç altın vererek eski dirliklerini geri almıştır. Bunun üzerine, mevcut dirlikli askerler Tebriz'den ayrılmış ve bu durum şehrin askerî düzenini bozmuştu. Hükümet sınır hattındaki nazik durumu göz önüne alarak bu tarz kusurların büyümesine izin vermemiştir. Bu maksatla mevzuyla alakalı ahkamlar yazıp Tebriz’e göndermiştir. ${ }^{143}$

141 Kar, a.g.t., s. 52-54.

142 Kar, a.g.t., s. 31-33.

143 BOA, A. DVN. MHM. d. 933, s. 1-2, 4-7. 
Barış umutlarını köreltip serhadde tekrar savaş heyecanı katan Şah Abbas endişesi çok geçmeden tesirini tümüyle yitirmiştir. Zira yeni şah yönünü Özbeklere çevirmiş ve Osmanlılarla mücadeleyi askıya almıştır. Horasan'da ilerleme kaydeden ve Safevi başkentini tehdit eden Özbek Abdullah Han Osmanlıları ve dolayısıyla Tebriz'de bulunan Cafer Paşa'yı rahatlatmışıtır. ${ }^{144}$ Fırsatı iyi değerlendiren Serdar Ferhad Paşa da Gence'yi fethetmiştir (Temmuz 1588). Şah tehlikesi ortadan kalkmış olmasına rağmen Cafer Paşa'nın cephesinde gelişmeler kesilmemiştir. Paşa önce Kahkaha Kalesi'nin hakimi Muhammed Sultan'ın Osmanlı Devleti'ne itaatini sunmak istediği haberini başkente ulaştırmıştır. III. Murad cevaben yazdığ 1 mektupta Cafer Paşa'ya Muhammed Sultan için Erdebil beylerbeyliği ve akrabalarına da muhtelif mansıplar vermeye hazır olduğunu bildirmiştir. Bu nedenle Cafer Paşa firsat bulduğu anda Kahkaha'ya varmalı ve kaleye bir Osmanlı garnizonu yerleştirmeliydi. III. Murad, Muhammed Sultan'a gönderdiği mektupta itaatini kabul edeceğini söylemiş ve vakit kaybetmeden Ferhad Paşa ile iletişime geçmesini istemiştir. Ayrıca Cafer Paşa ile beraber hareket edip firsat buldukça Safevi topraklarına ortak saldırı düzenlemeye teşvik etmiştir (Mart 1588). ${ }^{145}$

$\mathrm{Bu}$ gelişmenin yanı sıra, Hakkari'de zuhur eden bazı karışıklıklar da Cafer Paşa'yı meşgul etmiştir. Osmanlı hükümetinin görevlendirmesiyle uzun yıllardır Hakkari hakimliği yapan yerel Kürt aşireti Zeynel-oğulları arasında küçük çaplı hakimiyet krizi yaşanmıştır. Özdemiroğlu Osman Paşa'nın seferi sırasında öldürülen Zeynel Bey'in yerine Zekeriya Bey getirilmiş, fakat bölge ileri gelenleri yeni beyi kabul etmemişti. Diğer oğul Zahid Bey'in yönetici olmasını istemiş ve bunun için Cafer Paşa'ya başvurmuşlardı. Paşa'nın da yardımıyla Zahid Bey nihayet Hakkari hakimliğine tayin edilmiştir. Zekeriya Bey ise isyan başlatarak kardeşini öldürmüştü. Hükümet, ayaklanmayı öğrenince Cafer Paşa'ya Tebriz'de yeniçeri ve sipahilerden kifayet miktarını hemen Hakkari Beyi Melik Bey'in yanına sevk etmesini emretmiş̧tir. Zekeriya Bey, Tebriz'den gelen kuvvetlerle güçlenen Osmanlı birliklerine direnemeyeceğini anlayınca kaçmıştır. Bu aşamadan sonra, Melik Bey'in hırsından rahatsız olan Kürtler, tekrar Zekeriya' yı başlarında görmek istemiştir. Zekeriya Bey merkezin de desteğiyle yeniden Hakkari hakimliğine atanmıştır. ${ }^{146}$

144 Bu hükümlerde de Şah Abbas'ın babası emrinde on bin kişilik bir kuvveti Özbekler üzerine gönderdiğine dair bilgiler yer almıştır. Osmanlı hükümeti uzun süre Şah'ın Özbeklere mi yoksa Osmanlılara mı saldıracağını kestiremediğinden Tebriz korkusu gündemde kalmıştır. Şah Abbas döneminde Safevi-Özbek münasebetleri ve savaşları için bkz. Gülay Karadağ Çınar, “Safevî-Özbek Siyasî İlişkileri ve Osmanlı'nın Tesiri (1524-1630)", (Yayınlanmamış Doktora Tezi), Afyon Kocatepe Üniversitesi, Afyon, 2011, s. 190-270.

145 Kar, a.g.t., s. 47-51.

146 Zeki Tekin, “Zeynel Bey ve Oğullarının Hakkâri Hâkimliği Mücâdelesi ve İsyânları”, Atatürk Üniversitesi Sosyal Bilimler Enstitüsü Dergisi, cilt 10, say1 2, 2007, s. 126-128. 
Hadım Cafer Paşa'nın Tebriz muhafazasında iken başından geçen en ciddi hadise ise, Safevi ordusuyla yapılan meydan muharebesidir. Mustafa Âlî, tanıklara dayanarak rivayet ettiği savaşı, Cafer Paşa'nın Tebriz'e tayininden dört yıl sonraya tarihlendirir. Safevi sultanlarından on beşi bir araya gelerek Tebriz'i fethetme amaciyla Erdebil'e doğru harekete geçer. Yürüyüşleri esnasında Cafer Paşa'ya turna telleri, tîr ve keman, sorguç-1 zenan ve nâme-i istilâmet gönderirler. Safevi komutanları, Paşa'ya isterse "sorguç-1 zenanı giyip avret gibi oturmas1nı mert ise turna tellerini takıp" üzerlerine askerle gelmesini söyler. Cafer Paşa, düşmanın oldukça manidar ve küçük düşürücü bu harp çağrısını geri çevirmemiştir. Hemen cenk için mühimmat ve asker toplamak niyetiyle Kürd beylerine ulaklar yollamıştır. Kendisi de şehir dışına çıkıp otağını kurmuştur. Emrinde hiçbir eyalet paşası ve askeri olmamasına rağmen savaşa girmekten çekinmemiştir. Yaklaşan Safevi ordusuna karşı önce çarhacılarına saldırı emri verir. İki tarafın çarhacıları arasında gerçekleşen mücadelede Osmanlı güçleri üstün gelmiştir. Sonrasında Cafer Paşa emrindeki yirmi bin askerden oluşan orduyu aynı sayıdaki Safevi kuvvetlerinin üzerine doğru sürmüştür. Birliklerini üç bölüğe ayırdıktan sonra meydan savaşı başlamışıtır. İki saat süren savaşın sonunda Cafer Paşa galip gelmiş, Safevi ordugahını ele geçirmiş ve kaçan düşman ordusunu bir süre takip etmiştir. Daha sonra muzaffer birlikleri ile şehre geri dönmüştür. ${ }^{147}$

Cafer Paşa'nın bu zaferi ile beraber Tebriz'de Osmanlı hakimiyeti adeta resmiyet kazanmıştır. Muhtemelen bu savaşın ardından Şah Abbas bizzat kendisine bir mektup yazıp akim kalan barış görüşmelerini başlatmak istediğini bildirmiştir. ${ }^{148}$ Sulh için düşmanın talebi doğrultusunda Cafer Paşa'nın askerî harekatlarına tekrar sınırlandırılma getirilmiştir. III. Murad, kendisinden ikinci bir emre kadar Acem kalelerine ve topraklarına kesinlikle saldırmamasını emretmiştir. Erzurum'da bulunan Serdar Ferhad Paşa seferi sonlandırmışken; Paşa'nın da

147 Âlî, Künhü'l-Ahbâr, vr.557b-559b; Bu savaşın ne zaman gerçekleştiği ile alakalı kesin bir bilgiye erişilememektedir. Mustafa Âlî’nin kronolojisinde Ferhad Paşa'nın Tebriz'e yardım getirdikten sonraki dört sene boyunca Cafer Paşa'nın sorunsuz bir yönetim gösterdiği yazılır. Ferhad Paşa'nın 1586 yazında Tebriz'e vasıl olduğu düşünülürse Cafer Paşa'nın barış görüşmeleri başlamadan 1590 yılı içerisinde savaşma ihtimali yüksektir. Keza Peçevî de olayın H. 998 yılında (M. Kasım 1589-Ekim 1590) vuku bulduğunu belirtmektedir bkz. Peçevî, Târîh-i Peçevî, c. II, s. 113-115.

148 Koca Sinan Paşa III. Murad'a yazdığ 1 telhise Cafer Paşa'ya Şah Abbas'tan gelen nâmenin tercümesini eklemiştir bkz. Koca Sinan Paşa'nın Telhisleri, s. 139-140; Ayrıca Ekim 1589'da İran elçisi Mehdi Kulu Han'a barış şartları ve bölgede fethedilen yerlerle alakalı yazılan mektupta serhad ahvaline dair haberlerin Cafer Paşa'dan alındığı vurgulanmıştır bkz. BOA, A. DVNSMHM. ZYL. d. 4, hk. 195, 14 Zilhicce 998. 
bölgesinde askerî harekâtta bulunmaması istenmiştir. ${ }^{149}$ Bunun yanında Tebriz'in ele geçirilmesinde göstermiş olduğu gayret ve başarıya mükâfaten kendisine bir kabza kılıç ve bir takım hil'at armağan edilmiştir. ${ }^{150}$ Nihayet Serdar Ferhad Paşa Şah oğlu Haydar Mirza ve Safevi elçilik heyeti ile muzafferen İstanbul'a dönmüştür (Ocak 1590). Cafer Paşa ise Tebriz'i eyalet haline getirmek adına askerî ve idarî düzenlemelerle uğraşmıştır.

\section{Tebriz'de Askerî Düzen ve Hadım Cafer Paşa'nın Kapısı}

Cafer Paşa, Tebriz muhafazasında kaldığ 1 süre zarfında Van, Diyarbakır, Bağdat yahut serdar-1 ekremden gelen zahire ve hazine desteği ile emrindeki askeri birliklerin maaşlarını ödeyebilmiş ve gerekli ihtiyaçlarını karşılayabilmiştir. Bu durum daha önce de görüldüğü üzere mevaciblerini alamayan askerlerin Van'a yağma akınları düzenlemesine sebep olmuştur. Tebriz askerinin maaş ödemeleri yüzünden hoş görülmeyen hadiseler yaşanmaya devam etmiştir. Mesela Tebriz kullarının mevaciblerinin bu defa Halep hazinesinden tahsis edilmesi ferman olunduktan sonra Cafer Paşa yetmiş-seksen adamını ücreti toplamaları için şehre göndermiştir. Fakat Tebriz civarında inşa edilen kalelerdeki askerlerin bunlara katılmasıyla Halep'e yedi-sekiz yüz adem ulaşmıştır. Bu grup şehirde karışıklık çıkarınca, III. Murad Cafer Paşa'ya yeni bir ferman yazmıştır. Bundan böyle her kaleden sadece iki neferin maaşları almak üzere görevlendirilmesi aksi takdirde mevaciblerinin ödenmeyeceği uyarısı yapmıştır. ${ }^{151}$ Başka bir hadise de, Diyarbakır hazinesi Tebriz muhafazasında olan kula ocaklık tayin edilmişken düzenlemeden bî-haber Serdar Ferhad Paşa'nın hazineyi alması için adamlar göndermesidir. Buraya giden askerlerden Mustafa Çavuş şehirde karışıklık çıkarmış ve defterdarın evini basmıştır. Cafer Paşa'ya ise, Diyarbakır hazinesinin kendi askerine ocaklık olarak tahsis edildiği hatırlatılmış ve güvenilir adamlarını gönderip hazineyi teslim alması emredilmiştir. ${ }^{152}$

Hadım Cafer Paşa'nın Tebriz askerini idarede yaşadığı zorluklar seferler boyunca fethedilen bölgelerde benzerlerine s1k s1k rastlanan meselelerdi. Durumun farkında olan Sadrazam Koca Sinan Paşa III. Murad'a yazdığı telhiste, Gürcistan

149 BOA, $M D, 64$, hk. 78.

150 BOA, $M D, 64$, hk. 234.

151 BOA, $M D, 64$, hk. 416, 13 Zilhicce 996.

152 BOA, $M D$, 64, hk. 68, 10 Rebiyülevvel 997; Ferhad Paşa'ya aynı mesele hakkında gönderilen hüküm için bkz. BOA, $M D$, 64, hk. 56, 10 Rebiyülevvel 997; Başka bir hükümde Diyarbakır'dan verilen ücretlerin yetmemesi üzerine yeniçerilerden bazıları başkentte gitmek istemiş fakat Cafer Paşa'ya gönderilen hükümde onların muhafazada kalmaları emredilmiştir bkz. BOA, A. DVNSMHM. ZYL. d. 5, hk. 17. 
serhaddi üzerinden genel bir değerlendirme yapmıştır. Sadrazama göre serhadlerde bir bölük fukara birer kale içinde ikamet etmektedir ve taşradaki Acem reayası itaat etmediği müddetçe dışarıdan zahire ve hazine irsaliyle ilelebet geçinemeyecektir. Sadrazam, serhad paşalarına Gürcistan taraflarının tashihi için emirler göndermesine rağmen serdar baskısı olmazsa bu zahmetli işin yapılmayacağ fikrindeydi. Bu nedenle, Tebriz'deki Cafer Paşa yahut Diyarbakır'da bulunan Cigalazâde Sinan Paşa'dan birinin tashih işleri için vazifelendirilmesini III. Murad'a teklif etmiştir. ${ }^{153}$ Sinan Paşa'nın üzerinde durduğu tashih veya tahrir işini Cafer Paşa da uzun süre gerçekleştirememiştir. Gerek seferlerin devam etmesi gerekse Tebriz askerî ve ahalisinin uyum ve idare sorunu bunda etkili olmuştur. Keza merkezden kendisine gönderilen bir hükümde de Acem ve Gürcistan tahririnin ertelenmesinin nedeni bu minvalde açıklanmıştır. Tahrir işlemi başladığında bölge ahalisinin Osmanlı yönetimine nefreti artacaktır. Bu nedenle Serdar Ferhad Paşa tahrirden menedilmiştir. Aynı şekilde, Cafer Paşa'dan Tebriz'de tahrir yapmaması, önce reayayı geri getirmek için gereken tedbirleri alıp eyaletini mamur etmesi istenmiştir. ${ }^{154}$

Hazine ve tahrir sıkıntısı yaşamasına rağmen, Cafer Paşa Tebriz muhafazas1 için yeterli sayıda askere ve askerlerin vazifelerini sürdürmelerine dikkat etmiştir. Görevdeki ilk yılında, Şirvan ve sair yerlerden pek çok kişiye Tebriz'de kalmak şartıyla silahdarlık, müteferrikalık ve çavuşluk vermiştir. Yine muhtelif mevkilerdeki kişilerin Tebriz'de gösterdiği hizmetleri karşılığında terfi etmelerini veya terakki almalarını sağlamıştır. ${ }^{155}$ Ayrıca göreve başladığı 1585 yazından itibaren şehirde kalan yeniçerilerin cemaat ve bölükleri başta olmak üzere topçu, cebeci ve bu bölüklere dahil mansıplarına göre memurların isim, sayı ve yevmiyelerini kayda almıştır. Belirli aralıklarla bölüklere birer yahut ikişer akçe terakki vermiştir. Şehirdeki asker mevcudu ve onlara yaptıği terakkileri hükümetin isteğiyle defterlere kaydedip İstanbul'a göndermiştir. ${ }^{156}$ Bunun yanı sıra, Tebriz'deki vazifeli kul askerlerinin değiş-tokuş edildiği dönemler de olmuştur. Gence fethinden önce Tebriz'de bulunan kapı halkı Cafer Paşa'nın isteği

153 Koca Sinan Paşa'nın Telhisleri, s. 62-63.

154 BOA, $M D, 64$, hk. 339.

155 Cafer Paşa'nın ilk senesinde Tebriz'de yaptığı muhtelif tayinler ve diğer atamaların kayıtları için bkz. BOA, KK, d. 247, s. 65-73; BOA, KK. d. 248, s. 18; BOA, MD, 65, hk. 198.

156 Cafer Paşa'nın vazifesi boyunca Tebriz muhafazasında kalan yeniçeri, topçu, cebeci ve sair asker ve memurların isim, adet, maaşlarını ihtiva eden iki farklı defter bulunmaktadır. Toplamda yedi yüz sayfaya yakın bu defterler için bkz. BOA, MAD, d. 6514, 6134; Hükümetin vilayet-i Tebriz'deki kul askerinin sayısını deftere kaydetmesi ve başkentte göndermesi için Cafer Paşa'ya gönderdiği hüküm bkz. BOA, $M D, 69$, hk. 506. 
doğrultusunda kaldırılmış, onların boşluğunu Van askerleri doldurmuştur. Serdar Ferhad Paşa Gence'yi ele geçirince Van'dan gelen askerleri buraya nakletmek istemiştir. Van kullarının yerine Tebriz muhafazası için yeni askerler yazılmıştır. Fakat bir süre sonra Van kapı halkı Gence'ye gitmeyi reddetmiş ve şehirde kalmıştır. Bunun üzerine Cafer Paşa geri gelen askerleri yeniden istihdam edeceğine dair merkezi bilgilendirmiştir. III. Murad da mevaciblerini hak edenlere vermek şartıyla askerleri şehirde tutmasına izin vermiştir. ${ }^{157}$

Kapı kullarının idaresi dışında Cafer Paşa tımar ve zeamet hususunda da birçok düzenleme ve tayinât yapmıştır. Tımar meselesi ile alakalı ilk dikkat çeken durumlardan biri III. Murad'ın ona bazı uyarılarda bulunmasıdır. Sultan daha önce Tebriz kalesinde dört yüz müteferrikanın ulufe aldığını öğrenmiştir. Artık bu sayının yüze düşmesini uygun görmüştür. Paşa'ya geri kalan üç yüz müteferrikayı timara çıkarmasını ve bunların kayıtlarını deftere yazıp başkentte göndermesini emretmiştir. ${ }^{158}$ Ulufe yükünü azaltmaya yönelik bu tasarrufa Cafer Paşa uymuştur. Ağustos 1589 'dan itibaren başta Tebriz muhafazasındaki müteferrikalar olmak üzere gönüllüler ve süvarilerden pek çok kişiye timar vermiştir. Yalnız, sülüsan hesabı ile bağışlanan timarların bir kısmı Diyarbakır, Rum, Trabluşsam, Karaman, Hama ve Anadolu eyaletilerinden tayin edilmiştir. ${ }^{159}$ Dirliklerle alakalı başka bir hükümden bazı beratlı kimselerin timar ve zeametleri ellerinden alınınca dokuz yük akçe miriye zapt olunduğu ve bazılarının mukataa taleplerinin reddedildiği öğrenilmektedir. Bu tarz usulsüzlükler karşısında Cafer Paşa'ya elinde beratla gelenlere Tebriz'in mamur yerlerinden değil imar edilebilmesi için hâlî mahallerinden timar ve zeamet vermesi söylenmiştir. ${ }^{160}$ Diğer bir mesele ise zamanla Osmanlı idaresini tanıyan ve gelip Cafer Paşa'ya sadakatlerini sunan Kızılbaşlara verilen timar ve zeametlerle alakalıdır. III. Murad, Ocak 1591'de yazdığı hatt-1 hümâyûnda, Kızılbaşlara hâlî ve harap gösterilen yerlerden tımar ve zeamet berâtları verdiği için Paşa'yı eleştirmiştir. Zira buralar aslında havass-1

157 BOA, $M D$, 66, hk. 232; Daha sonra gönderilen bir hükümde Cafer Paşa'ya Van'dan ihraç olunan kullardan hizmette bulunmayan ve Tebriz'de mevcut olmayanlarına ulufe vermemesi emredilmiştir bkz. BOA, MD, 67, hk. 169.

158 Hükmün devamında Cafer Paşa'nın emre mugayir müteferrika sayısını arttırması eleştirilmiş ve bir daha müteferrika yazmaması tembih edilmiştir bkz. BOA, $M D$, 69, hk. 248.

15965 numaralı mühimme defterinde Ağustos 1589'dan Mart 1590'a kadar Cafer Paşa tarafından bağışlanan tımarlarla alakalı yirmiye yakın hüküm mevcuttur bkz. BOA, $M D, 65$, hk. 54, 79, 110, 111, 249, 289, 382, 403, 469, 479, 480, 496, 516, 641, 642, 1011, 1050, 1051.

160 Aynı hükümde Tebriz muharriri Ali'ye de bu emre göre amel etmesi emredilmiştir bkz. BOA, $M D, 64$, hk. 22; 995 senesinde bazı kişilerin İstanbul'a gelerek hükümetten tımar istemişler ve isteklerine uygun şekilde evâmir-i şerifler yazılıp verilmiştir. Cafer Paşa'ya da bu kişilere emre göre tımarlarını vermesi emredilmiştir bkz. BOA, MAD, d. 16024, s. 11-13. 
hümâyûna dahil edilmeye münasip karye ve mezraalardır. Bu nedenle bu mahalleri hass için zapt etmeyi ve Kızılbaşlara hudut bölgelerini şenlendirme şartıyla zeamet ve timar tahsis etmeyi emretmiştir. ${ }^{161}$

Cafer Paşa 1585 'den beri sürdürdüğü vazifesinin sonuna doğru Tebriz'in tahririni gerçekleştirebilmiştir. 1591 tarihli tahrire göre Tebriz eyaletine bağlı altı sancak bulunmaktadır. Bazı sancaklar Erdebil ve Megri hakimleri ile Cafer Paşa arasında anlaşmazlıklara neden olmuştur. Hükümet, Paşa'ya sulh antlaşmasından sonra Osmanlı hakimiyetine geçen bu yerlerin hakkını savunması için emirler dahi göndermiştir. ${ }^{162}$ Eyalette altı sancakla beraber 40 nahiye, 3 kasaba, 1064 köy, 106 mezraa, 61 dizeç, 61 kışlak ve 2 yaylak mevcuttur. Hâss, zeamet ve timardan müteşekkil dirliklerin türleri ve gelirleri de ayrıca kaydedilmiştir. Çıkan tabloya göre 1591-1592 yıllarında eyalet kapsamında iki padişah, bir mir-i mirân, beş sancakbeyi ve iki 'an hâss bulunmaktadır. Doksan üç zeamet, yirmi dokuz 'an zeamet ve kırk beş adet timar vardır. Toplamda Tebriz eyaleti 14 milyon akçe değerinde yüz yetmiş yedi dirlikten müteşekkildir. ${ }^{163}$

Tebriz'de mevcut yeniçeri ve timarlar yanında önemli bir askerî kuvveti Cafer Paşa'nın kapı halkı teşkil etmiştir. Mustafa Âlî, "zamân-1 devlet-i 'Âl-i Osmân'da tüfeng-endâz sekbânlara rağbet ü iksâr idüb çâk bu mertebede cem'iyyet evvelâ" Hadım Cafer Paşa'da görülmüştür diyerek tanımladığı bu güçlü kapının nasıl oluştuğunu da tafsilatlı anlatmıştır. Aslında, Cafer Paşa önce Tebriz ve daha sonra Şirvan'da edindiği ve tecrübe ve yaşadığı hadiseler nedeniyle meşhur kapısını meydana getirmiştir. Tebriz olayları daha önce birçok kez örneğine rastlanılan şehirdeki askerlerin ekonomik duruma dair şikayetleri yüzünden başlamıştır. ${ }^{164}$ Tebriz'in kapıkulu askerleri nısfiyye kesilen şâhinin değerine itiraz eder ve Cafer Paşa'yı askerin sıkıntılarından bihaber olmakla suçlar. Bir süre sonra on

161 BOA, MD, 67, hk. 180, 25 Rebiyülevvel 999.

162 Merage, Şahyurdu ve Bektaşsultan mahallerinin Kızılbaş’tan alınıp mukataaya dahil edildiğine ve Miğre hakiminin müdahalesini men etmesine dair Cafer Paşa'ya gönderilen hüküm için bkz. BOA, $M D, 69$, hk. 351; Bredgoş ve Germrud gibi mahallerde Erdebil hakimi ile anlaşmazlık çıkmasına rağmen sulh antlaşması imzalandığı için kavgaya ruhsat verilmemiştir. $\mathrm{Bu}$ nedenle Cafer Paşa'ya iki sınır arasındaki boş araziyi bir iki günlük mesafe bırakılarak anlaşma zemini oluşturması emredilmiştir bkz. BOA, MD, 67, hk. 272, 15 Cemaziyülevvel 999.

163 Orhan Kılıç, "III. Murad Devri İcmâl Defterlerine Göre Tebriz Eyaleti’nde Tımâr Düzeni”, XIII. Türk Tarih Kongresi Kongreye Sunulan Bildiriler III. Cilt-III. Klsım, Ankara: 4-8 Ekim 1999, Ankara, TTK, 2000, s. 1439-1460.

164 Daha geç tarihli olması münasebetiyle Aralık 1590'da Cafer Paşa hükümete yazdığı arzda Diyarbakır ve diğer yerlerden tayin edilen akçenin yeniçeriler ve diğer bölük halkının mevaciblerini yetmediğini belirtmiştir bkz. BOA, A. DVNSMHM. ZYL. d. 5, hk. 17, Evâil-i Safer 999. 
iki şâhiye câri olan guruş on sekize çıkınca ulufelerinin reel değerinin düştüğü gerekçesiyle askerin rahatsızlığ 1 iyice artar. Cafer Paşa ise, bir yandan şâhinin gümüşten kesilmesinin masrafa yetmediği diğer yandan nısfiyye kesilmesinin askeri memnun etmediği bir vaziyetle karşı karşıya kalır. Çare olarak, askerlere terakki verir ve onların şikayetini başta böyle geçiştirebilir. Lakin bir zaman sonra guruşun değeri otuz şâhiye yükselince aynı problemle tekrar yüzleşmek zorunda kalır. Kesilen akçe Tebriz dışında revaç bulmayınca kapıkulu askeri Paşa'nın sarayına saldıracak kadar ileri gider. Cafer Paşa da yapılan bu baskından kapı halkından iki yüz askerin yardımıyla ancak kurtulabilir. Kapıkullarının isyanını takip eden süreçte, Paşa sarayından çıkmaya cesaret edemediğinden Tebriz kontrolden çıkar. Şehrin bütün ekonomisine bölük halkından bir kısmı el koyar ve istedikleri gibi tasarrufta bulunur. Hatta, Cafer Paşa'nın kaçmasını önlemek için şehrin kapılarına duvar örerler.

Asilerin önlemlerine rağmen, Cafer Paşa kapı askerlerine daha sonra yanına gelmelerini tembihleyerek Tebriz'i terk eder. Paşa'nın şehirden ayrıldığını öğrenen asiler yaptıklarının cezasız kalmayacağını öngörerek, kendisine geri dönmesi için haber gönderirler. Paşa ise Hima civarına varmış ve bölgedeki Kürt beylerini emirlerindeki askerleriyle beraber otağına davet etmiştir. Bir süre sonra kapı halk1 da kendisine katılmıştır. Şehri asilerden geri almaya kararlı olan Paşa, gerekli askerî hazırlıklarını tamamlaya çalışır. Asilerin pişman olduklarına dair haber karargaha ulaşınca, Cafer Paşa kendisini öldürmeye yeltenen elli kişiyi teslim etmeleri halinde affedileceklerini ilan eder. Asilerin yoldaşlarını teslim etmekteki isteksizliği üzerine, Cafer Paşa, kapı askeri ve Kürt birlikleri ile Tebriz'in önüne gelir. Başarı şanslarının olmadığını anlayan asiler, talep edilen elli kişiyi öldürür; geri kalanlar da Cafer Paşa'nın huzuruna gelip tekrar itaatlerini sunar. Şehri adeta tekrar fetheden Cafer Paşa, şehri yağmalamaları için kendi sekbanlarına ve Kürtlere izin verir. ${ }^{165}$

Acem serhaddinde yeni fethedilmiş bir şehir ve eyaletteki koşullar askerlerin kontrolünü zorlaştırabilirken, Cafer Paşa'nın iktidarını da sarsmıştır. Mustafa Âlî̀ye göre "Devlet-i Aliyye-i Osmâniye'de değil selâtîn-i selef devletinde dahi olduğ 1 ne bir târihte görülmüş ne lisân-1 halkdan istimâ olunmuş" bu hadise Cafer Paşa'ya kapıkulu askerine karşı hem Tebriz idaresini hem de kendisini korumak için güçlü bir kapıya sahip olmanın önemini göstermiştir. Tebriz'deki isyan haberi başkentte ulaştığında, Paşa asi kullar karşısındaki mukavemeti yüzünden taltif edilmiştir. ${ }^{166}$ Tebriz muhafazasında yaşadığ 1 bu son olaydan sonra Hadım Cafer

165 Âlî, Künhü'l-Ahbâr, vr. 559b-563a; Ayrıca bkz. Peçevî, Târîh-i Peçevî, c. II, s. 115-120.

166 Selânikî’ye göre Tebriz'de yaşananları anlatmak için başkentte Cafer Paşa'nın adamları gelmiş 
Paşa Bağdad beylerbeyliğine tayin edilmiştir. Fakat buradaki idareciliği Bağdad'dan ayrılmak istediğini hükümete bildirince kısa sürmüştür. Bunun üzerine yararlıkları ve şecaatine binaen Şirvan muhafazası ile görevlendirilmiştir (Ağustos 1593). Bu vazifesi sirasinda Gürcistan meliklerinden Aleksandr'ın üzerine gönderilecek ordunun başına geçmesi emredilmiştir. ${ }^{167}$

Tebriz'deki başarılı yönetimine benzer şekilde, Hadım Cafer Paşa Şirvan'da da idarî ve askerî meziyetlerini sergilemiştir. Mesela, burada da Tebriz' de yaşanana benzer bir asker isyanı yaşanmış, ancak bu defa elebaşlarını hemen öldürerek isyanı sonlandırmıştır. ${ }^{168}$ Kendisinden sonra mamur olup geliri artan Tebriz'de ise kul mevacibi artık şehir hazinesinden ödenebilmiştir. Hatta zaman zaman Tebriz'deki vergi yahut tahrir ile ilgili hususlarda Cafer Paşa'dan yardım istenmiştir. ${ }^{169}$ Adaşı Emektar Cafer Paşa'dan sonra Şirvan'1 muhafaza hizmeti ününü ve kendisine duyulan güveni arttırmıştır. Öyle ki Sultan III. Mehmed'in Eğri seferi için İstanbul'a çağırılmış ve seferden önce kendisi Boğdan voyvodalığına terfi etmiştir (Mayıs 1595). ${ }^{170}$ Eğri fethine ve Haçova Meydan Muharebesine katılmış ve faaliyetleri ile seferin kilit isimlerinden biri olmuştur (1596). ${ }^{171}$ Seferden sonra tecrübesi dikkate alınarak kendisi tekrar Tebriz muhafazasına tayin edilmiştir. Tedbirleri sayesinde şehirdeki yeniçeri ayaklanmalarını ve yolsuzluklarını bastırmıştır (Ağustos 1597). "Umûmen serhadd-i mansûre askerine serdâr" olan Cafer Paşa hainlik eden Gürcistan Hakimi Simon'u da meydan savaşında esir etmiş ve İstanbul'a göndermiştir (1599). ${ }^{172}$ Hadım Cafer Paşa, Ocak 1601'de Tebriz'de vefat etmiştir. ${ }^{173}$

ve hadiseler üzerine Ağustos 1592 tarihinde kendisine hediyeler verilmesi emredilmiştir bkz. Selânikî, a.g.e., c. I, s. 284-285.

167 BOA, $M D, 69$, hk. 228, 10 Zilkade 1001; BOA, MD, 71, hk. 638; Selânikî, a.g.e., c. I, s. 317.

168 Şirvan isyanı ile alakalı bkz. Âlî, Künhü'l-Ahbâr, vr. 563a-564b.

169 BOA, $M D$, 70, hk. 418; BOA, $M D, 71$, hk. 112, 114.

170 Filiz Yıldırım, “1141 Numaralı ve 1593-1595 Tarihli Tahvîl Defteri (Transkripsiyon-Değerlendirme-Dizin)”, (Yayınlanmamış Yüksek Lisans Tezi), Fırat Üniversitesi, Elazığ, 2010, s. 62.

171 Cafer Paşa'ya seferden önce İstanbul'a gelmesini emreden hükümler için bkz. BOA, $M D, 73$, hk. 850, 1020.

172 Selânikî, a.g.e., c. II, s. 703, 833-835; Naîmâ Mustafa Efendi, Târih-i Naîmâ (Ravzatü'l-Hüseyn Fî Hulâsati Ahbâri'l- Hâfikayn), haz. Mehmed İpşirli, c. I, Ankara, TTK, 2007, s. 162.

173 Hadım Cafer Paşa'nın ölümünden sonra 17 Cemaziyülevvel 1010'da terekesi çıkarılmış ve metrukatındaki esbablar, ziynet eşyaları ve diğer eşyaları listelenmiştir. Metrukatı arasında uzun yıllar sürdürdüğü serhad görevlerine yaraşır biçimde mücevherlerle süslü ve değerli 10 adet k1lıç, 2 adet gürz, hançerler, kalkanlar dikkat çekmektedir bkz. TSMA. e. 0115. 


\section{Sonuç}

Yavuz Sultan Selim ve Kanuni Sultan Süleyman dönemlerinde gerçekleştirilen Safevi seferlerinden farklı olarak 1578-1590 arasındaki savaşlardan sonra Osmanlı Devleti fethettiği yerlerde idarî ve askerî düzen kurabilmiştir. Hakimiyetin birçok faktör nedeniyle uzun süremediği Tebriz ve Şirvan bölgelerinde başarıları faaliyetleriyle bu meşakkatli ve yorucu vazifeyi Cafer Paşalar yerine getirmiştir. Paşaların kaderleri ve kariyerlerinin şekillenmesinde Safevi seferlerinin meşhur serdarı Özdemiroğlu Osman Paşa'nın önemli bir etkisi olmuştur. Zira onlar Osman Paşa'nın vesilesiyle Demirkapı-Şirvan ve Tebriz muhafazalarına tayin edilmiştir. Birbirlerine çağdaş olmalarına ve uzak mesafelerde bulunmalarına rağmen ikisi arasında münasebet ve iletişime dair herhangi bir bilgi yoktur. Cafer Paşalar serhaddeki vazifeleri benzer yönlerine karşılık gelse dahi siyasi ve askerî tecrübeleri bakımından farklı karakterlere sahiptirler. Emektar Cafer Paşa Özdemiroğlu Osman Paşa'nın yerine Şirvan muhafazası için tercih edilebilecek bir olgunluğa erişmiştir. Daha önce Rumeli bölgesinde askerî meziyetleri sergileyebilmiş, başarılı işler yapabilmiştir. Diğer taraftan Hadım Cafer Paşa saraydan yeni çıkmış ve henüz kayda değer bir devlet adamı tecrübesi edinmemiş olmasına karşın Tebriz muhafazası gibi tehlikeli bir vazifeye atanmıştır. Tayininde kariyeri değil muhtemelen devlet adamları ile bağlantıları rol oynamıştır. Fakat askerî sahadaki tecrübesizliğine rağmen, Tebriz'de Safevi ordularının kuşatmasına on ay direnebilmiş ve buranın Osmanlı hakimiyetinde kalmasını sağlamıştır. Neticede ikisi de Şirvan ve Tebriz'e birer Osmanlı eyaleti mahiyeti kazandırmış ve Osmanlı Devleti'nin doğu sınırlarının genişlemesinde pay sahibi olmuştur. Emektar Cafer Paşa bu son görevinde vefat ederek ömrünü ve kariyerini sonlandırmıştır. Hadım Cafer Paşa ise Tebriz'de kazandığı askerî başarılar ve ün sayesinde Sultan III. Mehmed'in seferine dahi davet edilecek ve daha sonra Acem serhaddinin umûmî serdarı sayılacaktır. Cafer Paşaların tecrübeleri Osmanlı paşalarının askerî ve yöneticilik kariyerlerinin incelenmesi halinde yaşadıkları dönem için yeni anlatılar ve bakış açıları kazandırabileceğini de göstermiştir. 


\section{Kaynakça}

\section{Arşiv Kaynakları}

A. Cumhurbaşkanlığı Osmanlı Arşivleri (BOA)

Divan-1 Hümâyûn Mühimme Kalemi (A. \{DVN.MHM.)

Maliyeden Müdevver Defterleri (MAD)

Mühimme Defteri (MD)

Mühimme Zeyli Defterleri (A. \{DVNSMHM. ZYL.)

Nişan ve Tahvil Kalemi (A.\{NŞT)

Ruûs Kalemi (A. \{RSK)

Tapu Tahrir Defteri (TD)

Kâmil Kepeci (KK)

B. Topkapı Sarayı Arşivi

E. 0115

\section{Kaynak Eserler}

Âsafî Dal Mehmed Çelebi, Şecâ' 'atnâme, haz. Abdülkadir Özcan, İstanbul, 2007.

Don Juan of Persia: A Shi'ah Catholic, 1560-1604, haz. G. Le Strange, London, 1926.

Ebubekir bin Abdullah, Tevârih-i Osman Paşa, Bibliothèque nationale de France Département des manuscrits, Turc 123.

Eskandar Beg Monshi, History of Shah 'Abbas the Great (Tarik-e 'Alamara-ye Abbasi), haz. Roger M. Savory, Colorada, Westview Press, 1930.

Gelibolulu Mustafa Âlî, Nusret-nâme, haz. Mustafa Eravc1, Ankara, 2014.

Giovanni-Tomasso Minadoi, The War Between Turks and The Persians: Conflict and Religion in the Safavid and Ottoman Worlds, çev. Abraham Hartwell, London, 2019.

İbrahim Peçevî, Târîh-i Peçevî, c. II, İstanbul, Matbaa-1 Âmire, 1866.

Koca Sinan Paşa'nın Telhisleri, haz. H. Sahillioğlu, İstanbul, 2004.

Mehmed bin Mehmed er-Rumî, Nuhbetü 't-Tevârîh Ve'l-Ahbâr, Berlin Staatsbibliothek Orientalische Handschriften, Ms. or. fol. 4097.

Mustafa Âlî, Künhü'l-Ahbâr, Berlin Staatsbibliothek Orientalische Handschriften, Hs. or. 1090. 
Naîmâ Mustafa Efendi, Târih-i Naîmâ (Ravzatü'l-Hüseyn Fî Hulâsati Ahbâri’l-Hâfikayn), haz. Mehmed İpşirli, c. I, Ankara, 2007.

Rahimi-zâde İbrahim Çavuş Harimî, Kitâb-ı Gencîne-i Feth-i Gence, haz. G. Karaağaç, A. Eskikurt, İstanbul, 2010.

Rahîmî-zâde İbrahim Harîmî, Zafernâme-i Sultan Murad Han, İstanbul Üniversitesi Kütüphanesi Tarih Yazmaları Nr. 2372

Selânikî Mustafa Efendi, Tarih-i Selânikî, haz. Mehmed İpşirli, , c. I-II, Ankara, 1999.

Şeyh Vefâyi Mehmed, Tevârih-i Gazavât-ı Sultan Murad-ı Sâlis, ÖNB Department of Manuscripts and Rare Books, Cod. H. O. 66.

Târîh-i Osman Paşa, haz. Yunus Zeyrek, Ankara, 2001.

\section{Araștırma Eserler}

Aksoyak, İsmail Hakk1, "Gelibolulu Mustafa Âlî: Fursatnâme", Akademik Dil ve Edebiyat Dergisi, cilt 1, sayı 3, 2019.

Allahverdi, Reyhan Şahin, "Özdemiroğlu Osman Paşa ve Dönemi (15271585)", (Yayınlanmamış Doktora Tezi), Mimar Sinan Güzel Sanatlar Üniversitesi, İstanbul, 2012.

Asl, Lida Balilan, "The spatial structure of Tabriz in Safavid era in comparison with itineraries and pictorial documents", Bagh-e Nazar, cilt 13, sayı 38, 2016.

Aydın, Bilgin - Günalan, Rıfat, "Ruus Defterlerine Göre XVI. Yüzyılda Osmanlı Eyalet Teşkilatı ve Gelişimi”, Osmanlı Araştırmaları, sayı 38, 2011.

Blair, Sheila S., "Tabriz: International Entrepôt under the Mongol”, Politics, Patronage and the Transmission of Knowlodge in the 13th-15th Century Tabriz, ed. J. Pfeiffer, Leiden, Brill, 2014.

Bostan, İdris, "Cezayir-i Bahr-i Sefid Eyaletinin Kuruluşu (1534)", Tarih Dergisi, sayı 38, 2002-2003.

Charrière, Ernest, Négociations de la France dans le Levant ou Correspondance, Mémoires et Actes Diplomatiques, Paris, 1853.

Çetin, Atilla, “Garp Ocakları”, Türkiye Diyanet Vakfi Íslam Ansiklopedisi, cilt 13, 1996.

Eravc1, H. Mustafa, "Mühimme Defterlerine Göre Osmanlı Cezayir-i Garp", Gazi Akademik Bakış, sayı 20, 2017. 
Işıksel, Güneş, "Le statut de la Tripolitaine dans l'espace politique ottoman au xvie siècle", Hypothèses, sayı 16, 2013.

Kar, Serdar, “63 Numaralı Mühimme Defteri (995-996/1587-1588): Özet ve Transkripsiyon”, (Yayınlanmamış Yüksek Lisans Tezi), Marmara Üniversitesi, İstanbul, 2002.

Karadağ Çınar, Gülay, “Safevî-Özbek Siyasî İlişkileri ve Osmanlı'nın Tesiri (1524-1630)", (Yayınlanmamış Doktora Tezi), Afyon Kocatepe Üniversitesi, Afyon, 2011.

Karanfil, Mustafa, “Hârimi’nin Zafernâme ve Gonca'sına Göre Özdemiroğlu Osman Paşa”, (Yayınlanmamış Yüksek Lisans Tezi), İstanbul Üniversitesi, İstanbul, 1998.

Keshavarz, Zahrasadat - Montazerolghaem, Asghar - Hashemi, Shabnamsadat, "Assessing the Causation of Tradesmen Rebellion in Tabriz Through Institutionalisation Approach During Shah-Tahmasp Safavi Ruling (1571-1573 AD)", Iran: Journal of the British Institute of Persian Studies, 2021, (https://doi.org/10 .1080/05786967.2021.1882262)

Kılıç, Orhan, “16 ve 18. Yüzyıllarda Trablusgarp'ta Osmanlı Yönetimi ve Yöneticileri”, Prof. Dr. Salim Cöhce Armağanı: Tarihe Adanmış Çileli Bir Ömür, ed. Alpaslan Ceylan, Ankara, Berikan Yayınevi, 2017.

, "III. Murad Devri İcmâl Defterlerine Göre Tebriz Eyaleti'nde Tımâr Düzeni”, XIII. Türk Tarih Kongresi Kongreye Sunulan Bildiriler III. Cilt-III. Klsim, Ankara: 4-8 Ekim 1999, Ankara, TTK, 2000.

, "Beylerbeyilerden Dayılara Cezayir-i Garp Vilayeti/Eyaleti'nin Yönetimi ve Yöneticileri (16-18. Yüzylllar)", Cappadocia Journal of History and Social Sciences, say1 9, 2017.

Kırzıŏlu, Fahrettin, Osmanlıların Kafkas Ellerini Fethi (1451-1590), Ankara, Sevinç Matbaası, 1976.

Kunt, Metin, The Sultan's Servants: The Transformation of Ottoman Provincial Government, 1550-1650, New York, Columbia University Press, 1983.

Kütükoğlu, Bekir, Osmanlı-İran Siyâsî Münasebetleri (1578-1612), İstanbul, İstanbul Fetih Cemiyeti, 1993.

Matthee, Rudolph, The Politics of Trade in Safavid Iran: Silk for Silver, 16001730, Cambridge, Cambridge University Press, 2000.

, "The Ottoman-Safavid War of 986-998/1578-90: Motives and Causes", International Journal of Turkish Studies, cilt 20, say1 1-2, 2014. 
Naki, Emrah, "1574 Tunus Seferi Üzerine Yeni Bir Bakış”, OTAM, sayı 40, 2016, s. 129.

Ocakaçan, Levent Kaya, “Geç 16. ve Erken 17. yy'da Osmanlı Devleti'ndeki Patronaj İlişkilerinin Gazanfer Ağa Örneği Üzerinden Venedik Belgelerine Göre İncelenmesi”, (Yayınlanmamış Doktora Tezi), Marmara Üniversitesi, İstanbul, 2016.

Özçelik, Emirhan, "İmparatorluk Yönetiminde Savaşların Etkisi ve Osmanlı Paşaları (1566-1606)”, (Yayınlanmamış Yüksek Lisans Tezi), Bahçeşehir Üniversitesi, İstanbul, 2020.

Safvet, "Hazar Denizi'nde Osmanlı Sancağı", Tarih-i Osmani Encümeni Mecmuasl, sayı 14, 1912.

Şenlik, Songül, "232 Numaralı Ruus Defteri (Metin-Değerlendirme)", (Yayınlanmamış Yüksek Lisans Tezi), İstanbul Üniversitesi, İstanbul, 2014.

Taş, Abdullah Erdem, "Cezâyir-i Garb Vilâyeti'nin Kuruluşu Meselesi ve İlk Cezâyir Beylerbeyileri”, İslam Medeniyeti Araştırmaları Dergisi, cilt 5, sayı 2, 2020.

Wing, Patrick, "Rich in Goods and Abounding in Wealth: The Ilkhanid and Post-Ilkhanid Ruling Elite and the Politics of Commercial Life at Tabriz, 12501400", Politics, Patronage and the Transmission of Knowlodge in the 13th-15th Century Tabriz, ed. J. Pfeiffer, Leiden, Brill, 2014.

Y1ldırım, Filiz, “1141 Numaralı ve 1593-1595 Tarihli Tahvîl Defteri (Transkripsiyon-Değerlendirme-Dizin)”, (Yayınlanmamış Yüksek Lisans Tezi), Fırat Üniversitesi, Elazı̆̆ 2010.

\section{Araştırmacıların Katkı Oranı}

Araştırmanın her aşamasından yazar sorumludur.

\section{Çatışma Beyanı}

Araştırmada herhangi bir çıkar çatışması bulunmamaktadır. 
